\author{
UNIVERSIDADE DE SÃO PAULO \\ FACULDADE DE FILOSOFIA, LETRAS E CIÊNCIAS HUMANAS \\ DEPARTAMENTO DE GEOGRAFIA \\ PROGRAMA DE PÓS-GRADUAÇÃO EM GEOGRAFIA FÍSICA
}

Denise Dias dos Santos

ANÁLISE ESTATÍSTICA DAS PRECIPITAÇÕES NO LITORAL NORTE

PAULISTA: SUBSÍDIOS PARA A DETERMINAÇÃO DE EVENTOS EXTREMOS

Versão corrigida

São Paulo

2019 
DENISE DIAS DOS SANTOS

\section{Análise estatística das precipitações no Litoral Norte Paulista: subsídios para a determinação de eventos extremos}

Versão corrigida

Dissertação apresentada ao Programa de Pós-Graduação em Geografia Física da Faculdade de Filosofia, Letras e Ciências Humanas da Universidade de São Paulo para obtenção do título de Mestre em Ciências.

Orientador: Prof. Dr. Emerson Galvani Área de concentração: Geografia Física Linha de pesquisa: Estudos Teóricos e aplicados à Climatologia

Agência financiadora: CAPES - Código de financiamento 001

São Paulo 
Autorizo a reprodução e divulgação total ou parcial deste trabalho, por qualquer meio convencional ou eletrônico, para fins de estudo e pesquisa, desde que citada a fonte.

Catalogação na Publicação Serviço de Biblioteca e Documentação Faculdade de Filosofia, Letras e Ciências Humanas da Universidade de São Paulo

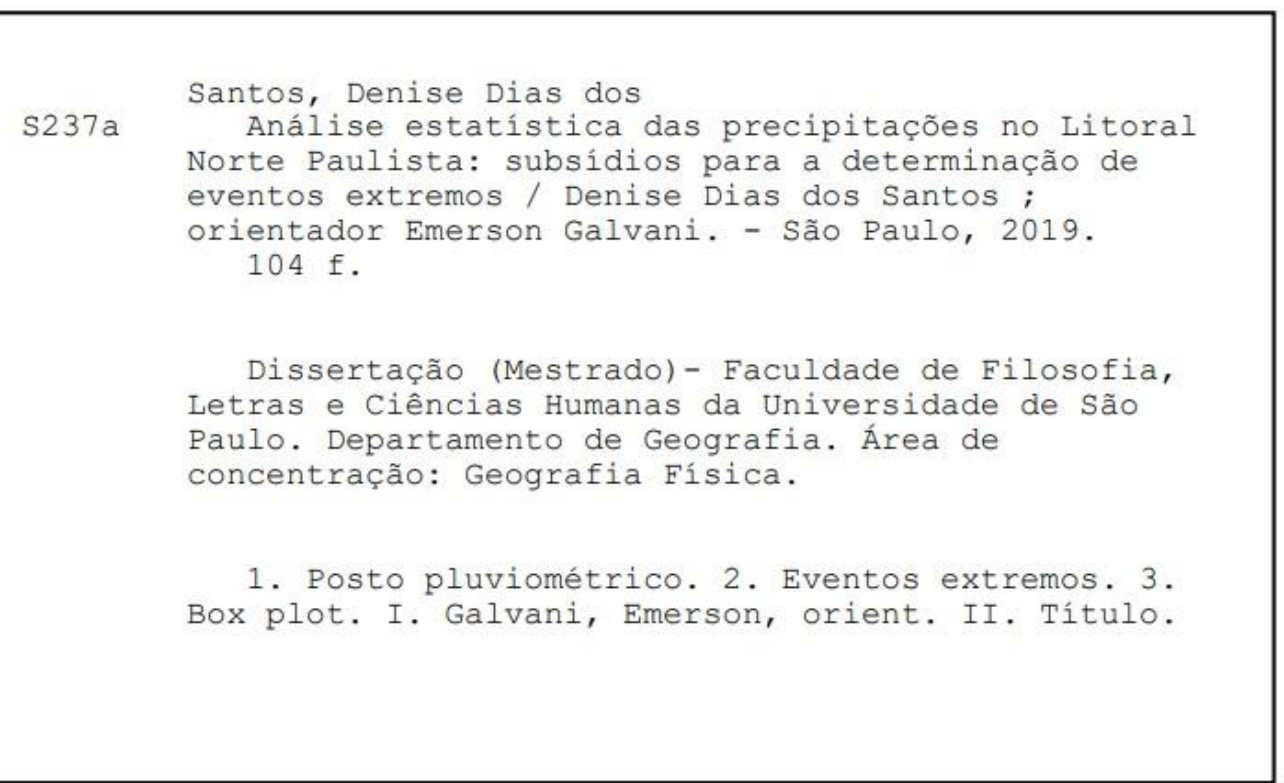




\section{ENTREGA DO EXEMPLAR CORRIGIDO DA DISSERTACÃO \\ Termo de Ciência e Concordância do orientador}

Nome da aluna: Denise Dias dos Santos

Data da defesa: 25/09/2019

Nome do Professor orientador: Emerson Galvani

Nos termos da legislaçäo vigente, declaro ESTAR CIENTE do conteúdo deste EXEMPLAR CORRIGIDO elaborado em atençäo às sugestöes dos membros da comissão Julgadora na sessāo de defesa do trabalho, manifestando-me plenamente favorável ao seu encaminhamento e publicaçăo no Portal Digital de Teses da USP.

São Paulo, 22/11/2019.

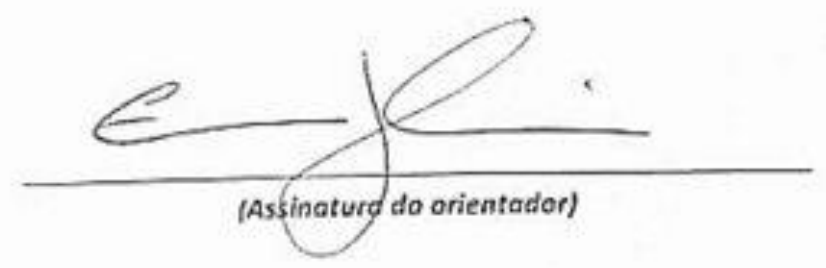


SANTOS, Denise Dias. Análise estatística das precipitações no Litoral Norte Paulista: subsídios para a determinação de eventos extremos. Dissertação (Mestrado) apresentada à Faculdade de Filosofia, Letras e Ciências Humanas da Universidade de São Paulo para obtenção do título de Mestre em Ciências.

Aprovado em:

Banca Examinadora

Prof. Dr. Emerson Galvani (Presidente/Orientador)

Instituição: FFLCH - Universidade de São Paulo - USP

Assinatura:

Prof. Dr. José Bueno Conti Instituição: FFLCH - Universidade de São Paulo - USP

Assinatura:

Dr. Gustavo Armani

Instituição: Instituto Geológico - IG/SIMA

Assinatura:

Prof. Dr. Alécio Perini Martins

Instituição: Universidade Federal de Goiás - UFG Regional Jataí

Assinatura: 


\section{AGRADECIMENTOS}

À minha família: Celma, Clemente e Rafael, pelo apoio, consolo e carinho. E por sempre acreditarem que a educação pode mudar a vida das pessoas.

Ao Prof. Emerson Galvani, orientador e amigo, sempre com bons conselhos e paciência para entender minhas limitações.

À Capes pelo auxílio financeiro concedido para o desenvolvimento desta pesquisa.

Aos professores do PPGF que contrubuíram com a minha formação durante estes três anos de mestrado.

À Ana Marília por ter aberto sua casa à minha pessoa, por cada palavra sensata, pelas "piadas ruins" e gargalhadas até em momentos difíceis.

Às queridas amigas, da universidade para a vida toda: Adriana Cirelli, Aline Fortunato, Bruna Paixão, Caroline Souza, Camila Cunha, Gabriela Mazza, Milla Oliveira, Rebeca Durço e Thais Leonardo: pelos conselhos, abraços, incentivo e admiração.

Aos amigos do LCB que sempre estão dispostos à ajudar: Nádia Lima, Rogério Rozolen, Sara Moraes, Miguel Terassi, João Paulo e Caroline Freire.

À Jakeline Baratto pelo auxílio com a cartografia, pelas "indiadas" e companhia por vários lugares do Brasil.

Às queridas amigas da pós-graduação: Camila Carou, Fabíola Magalhães e Maria Rita Pelegrin, parceiras de estudo, crises e boas risadas.

Ao Marcos, pela paciência, companhia e carinho adquiridos em tão pouco tempo.

À Cláudia, pelo auxílio em promover meu autoconhecimento.

Aos professores e colegas da EMEF Humberto Dantas e EMEF Arthur Alvim pelo incentivo e compreensão nos momentos difíceis de trabalho dentro e fora da sala de aula.

Aos meus alunos que todos os dias me fazem acreditar que a educação é o caminho certo para transformar o mundo. 
Tocando Em Frente Almir Sater

Ando devagar

Porque já tive pressa

E levo esse sorriso

Porque já chorei demais

Hoje me sinto mais forte

Mais feliz, quem sabe

Só levo a certeza

De que muito pouco sei

Ou nada sei

Conhecer as manhas

$E$ as manhãs

O sabor das massas

$E$ das maçãs

É preciso amor

Pra poder pulsar

É preciso paz pra poder sorrir

É preciso a chuva para florir

Penso que cumprir a vida

Seja simplesmente

Compreender a marcha

$E$ ir tocando em frente

Como um velho boiadeiro

Levando a boiada

Eu vou tocando os dias

Pela longa estrada, eu vou

Estrada eu sou

Conhecer as manhas

E as manhãs

O sabor das massas

$E$ das maçãs

É preciso amor

Pra poder pulsar

É preciso paz pra poder sorrir

É preciso a chuva para florir

Todo mundo ama um dia

Todo mundo chora

Um dia a gente chega

E no outro vai embora

Cada um de nós compõe a sua história

Cada ser em si

Carrega o dom de ser capaz

E ser feliz...

Composição: Almir Sater / Renato Teixeira 


\section{RESUMO}

SANTOS, Denise Dias. Análise estatística das precipitações no Litoral Norte Paulista: subsídios para a determinação de eventos extremos. Dissertação (Mestrado em Geografia Física). Faculdade de Filosofia, Letras e Ciências Humanas. Universidade de São Paulo: 101p., 2019.

Nas regiões tropicais, o estudo dos eventos extremos de precipitação possui devida importância, pois auxilia na prevenção dos impactos causados pelos desastres naturais, evitando perdas materiais e humanas. O Litoral Norte Paulista é, historicamente, marcado por eventos de precipitação intensos e possui características de relevo e solos que propiciam o desenvolvimento de desastres. $O$ objetivo deste estudo é realizar a análise das precipitações em uma feição climática definida por Monteiro (1973), que está inserida no Litoral Norte Paulista e, com o uso da técnica estatística do Box Plot, definir os limiares de ocorrência dos eventos extremos para três postos previamente selecionados. Os resultados apresentados demonstram que, em relação à média, há variabilidade da precipitação anual em todos os postos. Nas distribuições mensais é perceptível a presença da sazonalidade, com a concentração das chuvas na primavera e no verão e redução das mesmas durante o outono e inverno. Os gráficos de Box Plot definiram que os eventos extremos são aqueles que ultrapassam os valores de $99 \%$ do conjunto de dados e assim, definiram-se os limiares de evento extremo para cada posto. Os eventos extremos, assim como as precipitações totais, também apresentaram sazonalidade, corroborando com os resultados encontrados na literatura para a área de estudo. $\mathrm{Na}$ análise comparativa dos três postos pluviométricos, o posto E2-046 (em Caraguatatuba) obteve o maior número de registros de eventos extremos, porém o posto E2-009 (em Ubatuba) apresentou o maior valor extremo de 500,0 mm em 24 horas. Este resultado por ser explicado pela localização do posto na escarpa da Serra do Mar, que influencia o volume de precipitações ocorridas nesta localidade. A compreensão da origem e ocorrência dos eventos extremos é relevante para o planejamento de ações que permitam a previsão e prevenção das consequências dos desastres naturais na área de estudo. A pesquisa também aponta a importância da padronização do sistema de análise de eventos extremos para auxiliar nos estudos da relação entre precipitações e desastres no Litoral Norte Paulista.

Palavras chave: Posto pluviométrico. Eventos extremos. Box Plot 


\begin{abstract}
SANTOS, Denise Dias. Statistical analysis of rainfall in the Coastline of North São Paulo: subsidize for the determination of extreme events (Master Degree in Physical Geography). Faculty of Philosophy, Letters and Human Sciences. University of Sao Paulo: 101p., 2019.
\end{abstract}

In the tropical regions, the study of extreme rainfall events is important because it helps to prevent the environmental impacts caused by natural disasters, avoiding material and human damages. The State of São Paulo's North Coastline has historically been marked by intense rainfall events and features of relief and soil promote the development of disasters. The purpose of this study is to perform an analysis about the rainfall in a climatic feature defined by Monteiro (1973), which is inserted in the North Coastline of São Paulo and using the statistical technique of Box Plot, to define the thresholds of occurrence of extreme events for three previously selected rain gauges. The results presenter shows that in relation to the average, there are variability of the annual rainfall in all the rain gauges. In the monthly distributions, the presence of seasonality is observed, with the concentration of rainfall in spring and summer and reduction of rainfall during autumn and winter. The Box Plot graphics had defined the extreme events are those that exceed values above $99 \%$ of the data set and thus, the extreme event thresholds for each defined rain gauge. The extreme events, as well as the total precipitations, also presented seasonality, corroborating with the results found in the literature for the study area. In the comparative analysis of the three rain gauge, station E2-046 (in Caraguatatuba) obtained the highest number of records of extreme events, but on the E2-009 (in Ubatuba) station it was presented the highest extreme value of $500.0 \mathrm{~mm}$ in 24 hours. This result is explained by the location of the rain gauge on the escarpment of Serra do Mar, which influences the volume of rainfall occurred in this locality. The understanding of the origin and occurrence of extreme events is relevant in order to planning of actions that allow the prediction and prevention of the consequences of natural disasters in the study area. The research also points out the importance of the standardization of the system of analysis of extreme events to assist in the studies of the connection between rainfall and disasters in the North Coastline of São Paulo.

Key-words: Rain gauge. Extreme events. Box Plot. 


\section{LISTA DE ILUSTRAÇÕES}

Figura 1: Localização da área de estudo: feição climática definida por Monteiro (1973) 14

Figura 2: Mapa hipsométrico da área de estudo. ............................................16

Figura 3: Perfis SO-NE e NNE-SSW para a área de estudo. ...................................17

Figura 4: Classificação geomorfológica para a área de estudo. .............................18

Figura 5: Climograma para o município de Ubatuba (Normal Climatológica 19611990).

Figura 6: Extrato do balanço hídrico dos municípios da área de estudo (DEF são as deficiências hídricas e EXC são os excedentes hídricos)........................................21

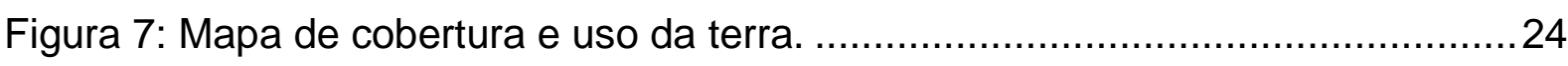

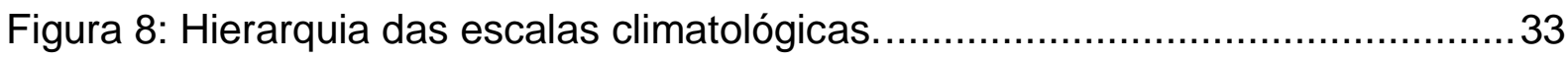

Figura 9: Classificação Climática do Estado de São Paulo. .....................................36

Figura 10: Distribuição das massas de ar na América do Sul segundo suas fontes e

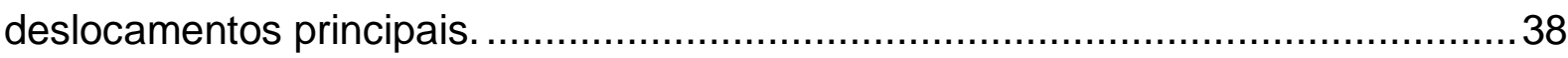

Figura 11: Localização dos postos pluviométricos na área de estudo. .....................46

Figura 12: Exemplo de representação de Box Plot. ................................................4 4

Figura 13: Distribuição anual da precipitação no posto E2-042................................49

Figura 14: Desvios absolutos em relação à média do posto E2-042. .......................50

Figura 15: Distribuição anual da precipitação no posto E2-043................................51

Figura 16: Desvios absolutos em relação à média do posto E2-043. .......................51

Figura 17: Distribuição anual da precipitação no posto E2-046 ...............................52

Figura 18: Desvios absolutos em relação à média do posto E2-046. ......................52

Figura 19: Distribuição anual da precipitação no posto E2-128...............................53

Figura 20: Desvios absolutos em relação à média do posto E2-128. .......................54

Figura 21: Distribuição anual da precipitação no posto E1-003..............................55

Figura 22: Desvios absolutos em relação à média do posto E1-003. .......................55

Figura 23: Distribuição anual da precipitação no posto E1-004 ..............................56

Figura 24: Desvios absolutos em relação à média do posto E1-004. ......................57

Figura 25: Distribuição anual da precipitação no posto E2-009..............................58

Figura 26: Desvios absolutos em relação à média do posto E2-009. .......................58

Figura 27: Distribuição anual da precipitação no posto E2-052 ……........................59

Figura 28: Desvios absolutos em relação à média do posto E2-052. .......................59 
Figura 29: Distribuição anual da precipitação no posto E2-122 …..........................60

Figura 30: Desvios absolutos em relação à média do posto E2-122. ......................60

Figura 31: Distribuição das precipitações médias mensais por posto pluviométrico. 63 Figura 32: Distribuição das precipitações médias mensais por posto pluviométrico. 64 Figura 33: Distribuição das precipitações médias mensais por posto pluviométrico. 65 Figura 34: Distribuição percentual sazonal das precipitações em cada posto pluviométrico. .67

Figura 35: Histogramas de frequência: E2-042, E2-043, E2-046 e E2-128. …..........68

Figura 36: Histogramas de frequência: E1-003, E1-004, E2-009, E2-052 e E2-122. 69

Figura 37: Box Plot para os postos E2-042 (a) e E2-043 (b) . .............................. 70

Figura 38: Box Plot para os postos E2-046 (a) e E2-128 (b) . ............................... 71

Figura 39: Box Plot para os postos E1-003 (a) e E1-004 (b). .............................. 72

Figura 40: Box Plot para os postos E2-009 (a) e E2-052 (b). ..............................73

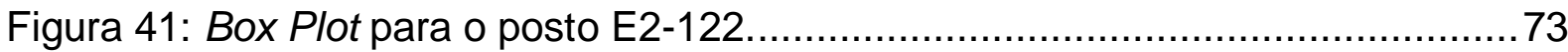

Figura 42: Comparativo do limiar definido para o evento extremo e as ocorrências das precipitações máximas diárias (por posto).

Figura 43: Número de eventos extremos de precipitação por ano no posto E2-046. 75 Figura 44: Número de eventos extremos de precipitação por ano no posto E2-009. 76 Figura 45: Número de eventos extremos de precipitação por ano no posto E2-122. 76 Figura 46: Classificação por quantis das precipitações anuais no Brasil para anos de El Niño em fase forte e com ocorrência de eventos extremos: 1966 e 1973. 78 Figura 47: Classificação por quantis das precipitações anuais no Brasil para anos de El Niño em fase forte e com ocorrência de eventos extremos: 1976, 1977, 1982, 1992, 1997 e 1998

Figura 48: Classificação por quantis das precipitações anuais no Brasil para anos de El Niño em fase forte e com ocorrência de eventos extremos: 1969, 1970, 1979, 1980, 1986 e 2006. 80

Figura 49: Distribuição mensal dos eventos extremos (números absolutos). 


\section{LISTA DE TABELAS}

Tabela 1: Classificação climática de Köppen para os municípios da área de estudo. 20

Tabela 2: Classificação dos solos da área de estudo.........................................22

Tabela 3: Dados de área, população e densidade demográfica dos municípios da

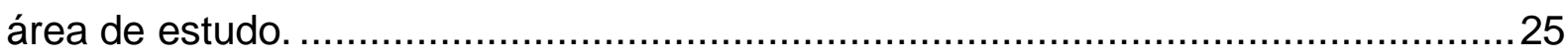

Tabela 4: Organização das escalas espacial e temporal do clima. ...........................34

Tabela 5: Localização dos postos pluviométricos e porcentagem de falhas do banco de dados. 45

Tabela 6: Dados estatísticos gerados a partir do Box Plot. Valores em mm.............70 Tabela 7: Coeficientes de correlação entre eventos extremos de precipitação e o

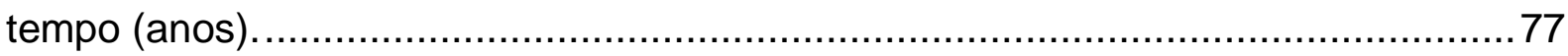

Tabela 8: Número de extremos de precipitação por mês (absolutos e percentuais). 82 


\section{LISTA DE ABREVIATURAS E SIGLAS}

$\begin{array}{ll}\text { ASAS } & \text { Alta Subtropical do Atlântico Sul } \\ \text { CCM } & \text { Complexo Convectivo de Mesoescala } \\ \text { DAEE } & \text { Departamento de Águas e Energia Elétrica } \\ \text { ENOS } & \text { El Niño Oscilação Sul } \\ \text { FPA } & \text { Frente Polar Atlântica } \\ \text { IBGE } & \text { Instituto Brasileiro de Geografia e Estatística } \\ \text { JBN } & \text { Jato de Baixos Níveis } \\ \text { LI } & \text { Linha de Instabilidade } \\ \text { LNP } & \text { Litoral Norte Paulista } \\ \text { mm } & \text { milímetros } \\ \text { mPa } & \text { Massa Polar Atlântica } \\ \text { mTc } & \text { Massa Tropical Atlântica } \\ \text { mTc } & \text { Massa Tropical Continental } \\ \text { OMM } & \text { Organização Meteorológica Mundial } \\ \text { PESM } & \text { Parque Estadual da Serra do Mar } \\ \text { RMVPLN } & \text { Região Metropolitana do Vale do Paraíba e Litoral Norte } \\ \text { SF } & \text { Sistema Frontal } \\ \text { SO-NE } & \text { Sudoeste-Nordeste } \\ \text { UC } & \text { Unidade de conservação } \\ \text { ZCAS } & \text { Zona de Convergência do Atlântico Sul } \\ \text { ZCIT } & \text { Zona de Convergência Intertropical } \\ \text { ZCOU } & \text { Zona de Convergência de Umidade }\end{array}$




\section{SUMÁRIO}

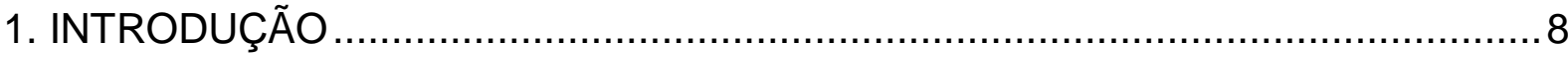

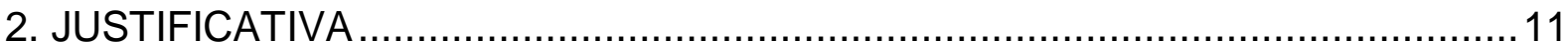

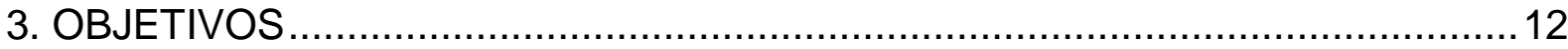

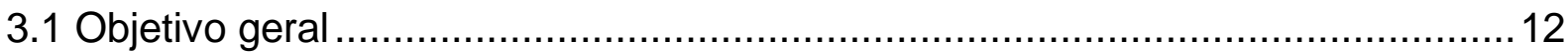

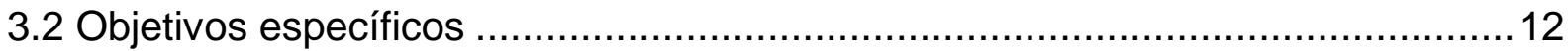

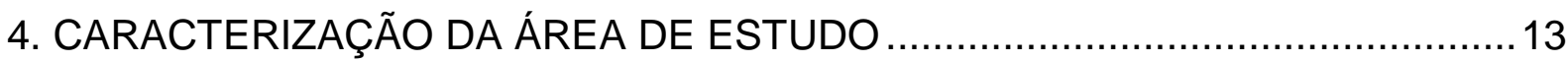

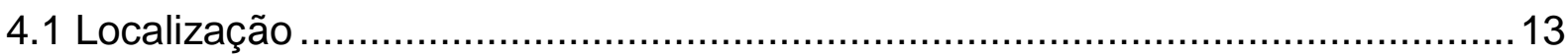

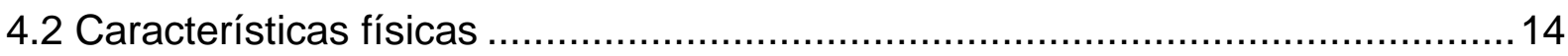

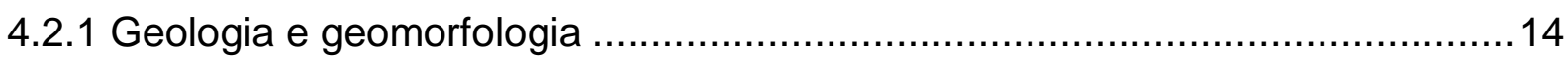

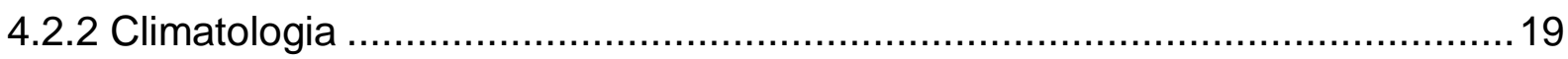

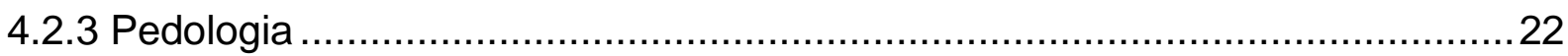

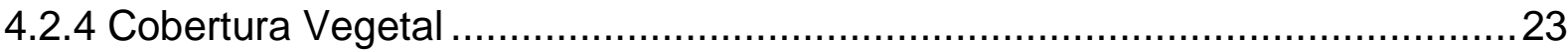

4.3 Características socioeconômicas ......................................................... 25

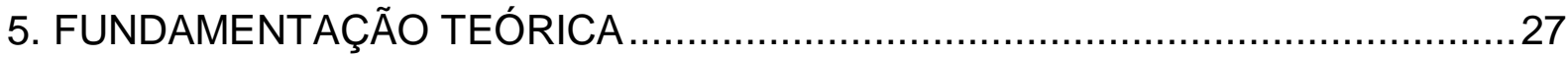

5.1 Precipitação pluviométrica: conceitos e técnicas de análise ..........................27

5.2 Escalas de abordagem em Climatologia Geográfica .....................................31

5.3 Feições climáticas do LNP - Monteiro, 1973......................................... 34

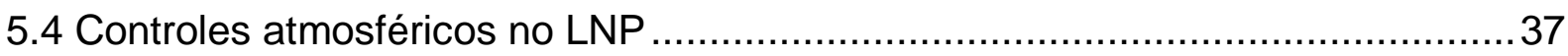

5.5 Eventos extremos de precipitação: conceitos e estudo de casos .....................41

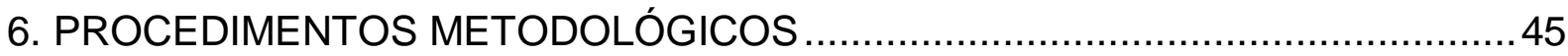

6.1 Seleção e organização do banco de dados ............................................ 45

6.2 Análises estatísticas e definição de eventos extremos ...............................46

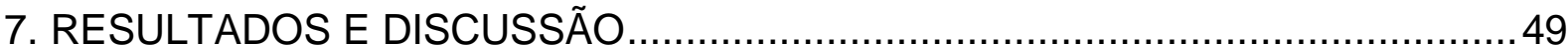

7.1 Estatística descritiva dos postos pluviométricos .......................................49

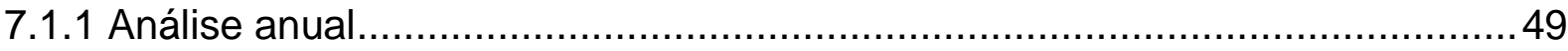

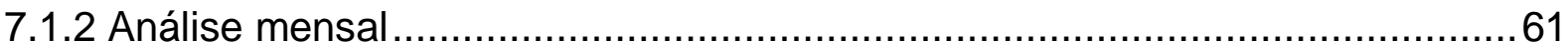


7.1.3 Análise sazonal

7.1.4 Análise diária.

7.2 Eventos extremos

7.3 Comparativos de eventos extremos em três postos

8. CONSIDERAÇÕES FINAIS 83

REFERÊNCIAS 86

ANEXOS .95 


\section{INTRODUÇÃO}

O objetivo do estudo da Climatologia, com suas diversas linhas teóricas, é compreender a importância desta ciência para o desenvolvimento da vida no planeta Terra. É fato que para meteorologistas, geógrafos e demais estudiosos do clima a Climatologia se apresenta de maneiras diferentes, de acordo com as necessidades de cada linha de pesquisa e a forma como se apropria de seu objeto de estudo - a atmosfera. De acordo com Sorre (1934), as descargas elétricas, a condensação do vapor d'água, os relâmpagos, entre outros fenômenos, são objetos de estudo da Meteorologia, área que se utiliza da física para explicar os fenômenos que ocorrem na atmosfera. As variações geográficas da precipitação ocorridas em determinado local, a interação dos atributos climáticos (temperatura, umidade, ventos, etc.) com o relevo, os solos, a vegetação e os seres humanos são de interesse dos geógrafos, que procuram compreender as relações e interações entre natureza e sociedade.

Sorre (1934) introduz o conceito de "ritmo" ao considerar que o clima é uma série de estados da atmosfera sobre um lugar em sua sucessão habitual, contrariando a linha teórica de Hann, que considerava o clima como uma média, transformando-o numa abstração (BARROS; ZAVATTINI, 2009). Tem-se, então, a categorização de duas linhas na Climatologia: a Analítico-Separatista, que separa elementos climáticos, calcula-se as médias, dissolvendo a realidade; e a Sintética, onde cada tipo de tempo deve ser analisado a partir dos seus elementos (ou atributos) constituintes. A primeira traz um equívoco importante, pois mascara e desconsidera a existência dos extremos, que são essenciais para as análises climáticas a nível local e regional.

No Brasil, Monteiro $(1971 ; 1973)$ foi responsável por desenvolver o conceito de ritmo climático, considerando que ele é o encadeamento sucessivo e contínuo dos estados atmosféricos. Em suas análises, procurou trabalhar com as abordagens tradicional e dinâmica, sendo complementares entre si, como meio de desenvolver uma análise rítmica do clima fidedigna. A abordagem tradicional (quantitativa) tem o foco na observação e registro, considerando os valores médios que permitem apontar frequências, amplitudes e tendências; são dependentes de uma rede confiável de observação e possuindo uma distribuição espacial homogênea. Já a abordagem dinâmica (qualitativa) trabalha com amostras cronológicas por episódios, períodos, anos-padrão, por vezes com o uso de eixos ou transectos que permitam a 
reflexão de mecanismos "habituais" e "excepcionais". Com isso, a análise rítmica favorece o estudo das condições da dinâmica climática e dos tipos de tempo atmosférico. De acordo com Monteiro (1971), as análises quantitativas e qualitativas devem integrar-se ao espaço regional. Os parâmetros que são admitidos para uma área específica podem não ser válidos para outra e, consequentemente, o pesquisador poderá definir o que é habitual e o que é excepcional para cada área.

Segundo Barros e Zavattini (2009), a chuva é definida como o melhor atributo que traduz as variações rítmicas em um dado período no meio tropical e subtropical. Nas áreas tropicais do planeta, a precipitação é o atributo do clima que provoca mudanças rápidas na paisagem, principalmente no período chuvoso, onde ocorrem episódios de precipitações concentradas e intensas. Alguns destes episódios desencadeiam os eventos extremos, que podem causar desastres naturais de diversas magnitudes (TAVARES, 2012). Os fatores que influenciam os desastres causados pelos eventos extremos de chuva são: intensidade e duração do evento, relevo (declividade, tipo de solos, presença ou não de cobertura vegetal) e o grau de ocupação do solo.

Com o objetivo de minimizar os danos causados pelos desastres naturais, organizações e institutos de pesquisa promovem estudos com a finalidade de avaliar as áreas susceptíveis. Trabalhos como zoneamento, setorização, hierarquização do grau das áreas de risco de escorregamentos (IPT, 2010) auxiliam na prevenção e resolução de problemas resultantes dos desastres. Contudo, é importante analisar também os fatores que provocam as catástrofes. Os eventos extremos de precipitação são responsáveis pela maioria dos desastres naturais que causam perdas materiais e humanas e o estudo da ocorrência e variabilidade dos mesmos faz-se necessário para que haja melhorias no sistema de previsão e prevenção.

No Estado de São Paulo, os desastres são associados aos escorregamentos em vertentes, inundações, enchentes e erosão acelerada (TOMINAGA, 2012). Especificamente no Litoral Norte Paulista (LNP), escorregamentos, erosão costeira e inundações estão atrelados às precipitações convectivas durante a primavera/verão e à passagem de sistemas frontais no outono/inverno. A compartimentação do relevo, as características dos solos e a ocupação humana em terrenos irregulares contribuem com o agravamento dos eventos.

Para Nunes (1992), pesquisas de precipitação de ordem anual são adequadas para relatar diferenças espaciais e temporais em análises climáticas. 
Contudo, variações temporais são melhores representadas em escala de menor detalhe, como a mensal. Para a correlação entre eventos pluviométricos e desastres naturais que envolvem escorregamentos e encostas, as análises dos dados de ordem diária e horária são as melhores recomendadas, visto que as situações de risco ocorrem com a alta concentração de chuvas em um curto espaço de tempo.

No LNP, fatores como a latitude, o relevo e a alta umidade que se desloca do Oceano Atlântico para o continente interferem no clima local e em toda a zona costeira. Tal configuração proporciona uma distribuição das chuvas peculiar, em que não é possível estabelecer uma estação seca e há a ocorrência de eventos extremos. Estes eventos podem ocorrer em várias escalas de tempo, de diária a mensal e sazonal (CAVALCANTI, 2012). As inundações e deslizamentos ocorrem quando, principalmente em área urbana, os excessos de chuvas (relacionados a células convectivas profundas, muitas vezes embutidos em sistemas sinóticos que podem persistir sobre a área) são combinados com alta impermeabilização do solo e ocupação em áreas de alta susceptibilidade aos escorregamentos, causando perdas e danos não somente materiais, mas também humanos. 


\section{JUSTIFICATIVA}

A área de estudo tem importância turística para o Estado de São Paulo e pertence ao Domínio dos Mares de Morros, sendo o "meio físico, ecológico e paisagístico mais complexo e difícil do país em relação às ações antrópicas" e "tratase, ainda, da região sujeita aos mais fortes processos de erosão e de movimentos coletivos de solos em todo território brasileiro (faixa Serra do Mar e bacia do Paraíba do Sul)" (AB'SÁBER, 2003, p.17). A presença da Serra do Mar influencia a chegada e o deslocamento de sistemas atmosféricos comuns do clima transicional da região.

Atualmente, a localidade se destaca pelo crescente desenvolvimento urbano, como as obras do novo Porto de São Sebastião, o Gasoduto CaraguatatubaTaubaté e a duplicação da Rodovia dos Tamoios (trechos de planalto e de serra), que atraem investimentos em infraestrutura comercial e turística, bem como o deslocamento de novos moradores e visitantes para áreas que antes não eram povoadas e/ou ocupadas. Ao estudar a percepção climática de trabalhadores do ramo da pesca no município de Caraguatatuba, Seixas (2014) afirma que as instabilidades atmosféricas provocam "ressacas" no mar; em conjunto, a mudança na direção dos ventos provocam alterações nas correntes marinhas e prejudicam a pesca. Para os trabalhadores, o maior desafio é a previsão das condições de tempo em curto prazo, de modo a proporcionar menores impactos quando há a ocorrência de eventos extremos que provocam estas alterações atmosféricas e marítimas.

O estudo dos eventos extremos de chuva também é importante para previsão e prevenção de desastres naturais. Porém, para cada região deve-se avaliar qual metodologia é adequada para a definição do evento extremo. Segundo Antunes (2015), a adoção de critérios definidos por outros autores pode ser inadequada, visto que as características climáticas das áreas de estudo podem não ser semelhantes. 


\section{OBJETIVOS}

\subsection{Objetivo geral}

A presente pesquisa tem como objetivo analisar as precipitações ocorridas em uma feição climática definida por Monteiro (1973), inserida no Litoral Norte Paulista, com foco na ocorrência de eventos extremos.

\subsection{Objetivos específicos}

Como objetivos específicos, temos:

- Analisar do ponto de vista diário, anual, mensal e sazonal as precipitações nos nove postos localizados na área de estudo, em diversos períodos, com dados fornecidos pelo Departamento de Águas e Energia Elétrica (DAEE);

- Com o uso da técnica de Box Plot, definir o limiar de ocorrência dos eventos extremos para cada posto pluviométrico;

- A partir de três postos de referência, comparar os registros de eventos extremos: número de ocorrências, correlação com o tempo (em anos) e associação com o El Niño. 


\section{CARACTERIZAÇÃo DA ÁREA DE ESTUDO}

\subsection{Localização}

De acordo com Silva (1975), os geógrafos brasileiros iniciaram os estudos sobre o litoral do Estado de São Paulo a partir da década de 1940, sendo João Dias da Silveira o pioneiro na área. França (1951) estudou a llha de São Sebastião "com amplas e minuciosas considerações a respeito do Litoral Norte" (SILVA, 1975, p.8). Posteriormente, na área da Geomorfologia, merece destaque Cruz (1974), que estudou a Serra do Mar e o litoral na região de Caraguatatuba, principalmente com contribuições acerca dos desastres naturais ocorridos em março de 1967. $\mathrm{Na}$ Climatologia, uma das obras de grande relevância é de Conti (1975), que desenvolveu um trabalho detalhado sobre a gênese das chuvas na porção lesnordeste do Estado de São Paulo, com ênfase à circulação secundária e ao efeito orográfico na parcela litorânea da sua área de estudo.

A figura 1 ilustra a localização da área de estudo, que possui $1.321,150 \mathrm{~km}^{2}$. Está inserida no Litoral Norte do estado de São Paulo, pertencente à Região Metropolitana do Vale do Paraíba e Litoral Norte - RMVPLN (EMPLASA, 2018). O LNP faz divisa com o município de Cunha e o estado do Rio de Janeiro ao norte, o Oceano Atlântico a leste e ao sul, Bertioga e Salesópolis a oeste, Paraibuna, Natividade da Serra e São Luis do Paraitinga a noroeste, com área total de $1.941,836 \mathrm{~km}^{2}$ e uma população total de 323.991 habitantes.

A área de estudo também contempla a presença de uma importante unidade de conservação do estado de São Paulo, que é o Parque Estadual da Serra do Mar (PESM), que é uma área de proteção integral. Há dois núcleos do PESM existentes na feição climática estudada (Caraguatatuba e Picinguaba), onde é possível realizar visitas, trilhas, atividades de educação ambiental, entre outros eventos importantes para a manutenção da UC. A localização da mesma é de grande importância na delimitação do avanço da área urbana dos municípios da região. 
Figura 1: Localização da área de estudo: feição climática definida por Monteiro (1973).
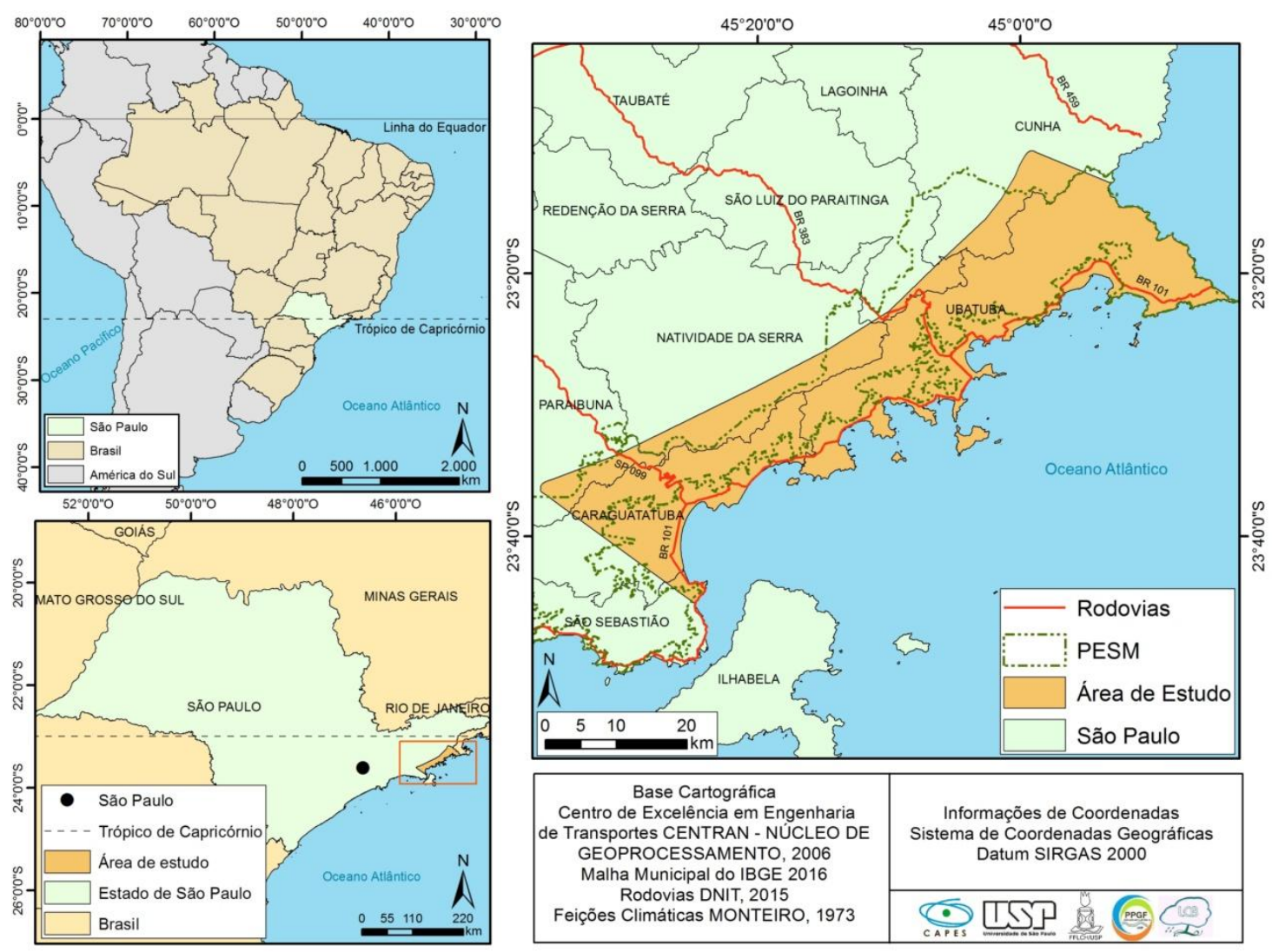

Org: Santos e Baratto, 2019.

\subsection{Características físicas}

\subsubsection{Geologia e geomorfologia}

Para AB'Sáber (1955), as vertentes orientadas para o Oceano Atlântico no estado de São Paulo fazem parte da área de maior complexidade no estudo dos processos geológicos e na história da geomorfologia do sudeste brasileiro. Segundo o autor

foi a última área de relevo e drenagem a se definir no edifício topográfico e tectônico do estado, possuindo uma evolução geomorfológica inteiramente posterior ao cretáceo, estando relacionada fundamentalmente ao tectonismo que fragmentou a porção sul-oriental do Escudo Brasileiro (p.6).

O passado geológico da região possui dois momentos: o primeiro, mais antigo, relacionado "aos fins do cretáceo e eocênico, quando se processaram os grandes falhamentos do Brasil Sudeste, responsáveis pela gênese das principais escarpas de falhas do Planalto Atlântico"; e o segundo, mais recente, "em pleno 
cenozoico e no quaternário, está ligado aos relevos epicíclicos [grifo do autor] da zona costeira, (...) relacionados com a interferência dos movimentos epirogênicos ${ }^{1} \mathrm{e}$ eustáticos 2 ." (AB'SÁBER, 1955, p.7)

Almeida (1974) realizou a divisão do estado de São Paulo em províncias geomórficas. A área de estudo insere-se na Província Costeira, área drenada diretamente para o oceano, que constitui o rebordo do Planalto Atlântico. Esta província é subdividida em Serrania Costeira (Serra do Mar, contínua) e as baixadas litorâneas (descontínuas). A primeira, de acordo com o autor, é uma estrutura geológica de sustentação, com origem granito-gnaissica, principalmente nos trechos das serras do Juqueriqurê e Parati. Já a segunda subdivisão possui terrenos com aspectos diversificados, com maiores extensões nos trechos da Baixada Santista. As oscilações do nível do mar deixaram vestígios marcados nos terraços marinhos e nos vales fluviais maiores. Os terrenos de planícies atuais formam baías que recebem depósitos marinhos e fluviais; são mais desenvolvidas no setor de Santos a Cananéia do que no Litoral Norte, onde as escarpas da Serra do Mar chegam quase diretamente ao mar em alguns trechos.

A Serra do Mar, até o sul do município de São Sebastião, é contínua e próxima ao oceano, com "paisagens de potencial paisagístico, pela alternância de enseadas e costões". Suas altitudes são variáveis entre 800 e 1200 metros, permitindo a transposição para a unidade de relevo vizinha (planalto), que foram desenvolvidas em Caraguatatuba e Ubatuba (TITARELLI, 1986). Um bom exemplo são as rodovias que dão acesso do Vale do Paraíba para estes dois municípios: Rodovia dos Tamoios, que faz a ligação entre São José dos Campos (planalto) e Caraguatatuba, e Rodovia Oswaldo Cruz, que faz a ligação entre Taubaté (também no planalto) com Ubatuba.

Cruz (1986) define a área norte do litoral paulista como um compartimento geomorfológico de extrema importância, que possui embasamento pré-cambriano, com contatos litológicos diferenciados e cicatrizes de origem tectônica, formado por uma associação de vertentes escarpadas que fazem a divisão do planalto. As áreas

\footnotetext{
1 "Movimentos de subida ou descida de grandes áreas da crosta terrestre, de modo lento. Caracteriza-se por um reajustamento isostático de área, dominando assim os movimentos verticais lentos, por vezes seculares." (GUERRA, 2008, p.225).

2 "Termo criado por Suess para designar as variações lentas do nível dos mares. Os movimentos eustáticos podem ser: positivos - quando as águas invadem as terras, também chamados de transgressões marinhas; negativos - quando as águas se afastam da linha litorânea, também denominados regressões marinhas." (GUERRA, 2008, p.258).
} 
costeiras são definidas pelo litoral e suas planícies, formando um sistema cujas inter-relações devem ser consideradas nas pesquisas, análises e planejamentos sobre este espaço.

Segundo Almeida e Carneiro (1998), a Serra do Mar é um conjunto de escarpas festonadas com cerca de $1.000 \mathrm{~km}$ de extensão, em que termina o Planalto Atlântico no trecho voltado para a Bacia de Santos. Ela se estende do Rio de Janeiro ao norte de Santa Catarina, onde termina como unidade orográfica de borda escarpada de planalto. No estado de São Paulo, impõe-se como típica borda de planalto, frequentemente nivelada pelo topo em altitudes de 800 a 1.200 metros (figura 2). Sua origem geológica é datada do período pré-cambriano, mas os dobramentos modernos responsáveis por suas escarpas e solos são de origem quaternária. A figura 3 apresenta os perfis Sudoeste/Nordeste e Nor-nordeste/Sulsudoeste e para a área de estudo.

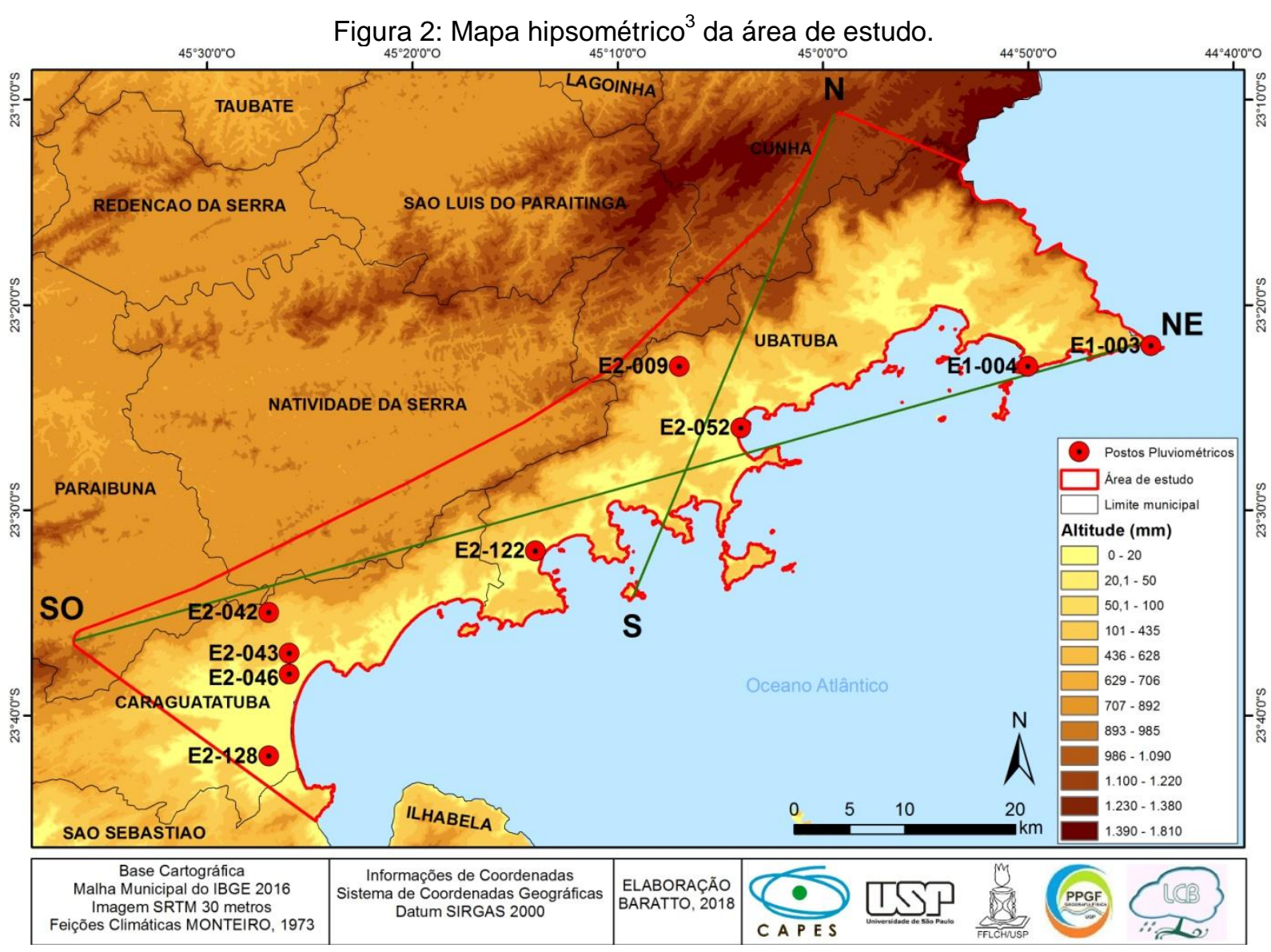

Org: Santos e Baratto, 2019.

\footnotetext{
${ }^{3}$ As classes de altitudes do mapa foram definidas de acordo com a realidade de representação na área de estudo.
} 
Figura 3: Perfis SO-NE e NNE-SSW para a área de estudo.
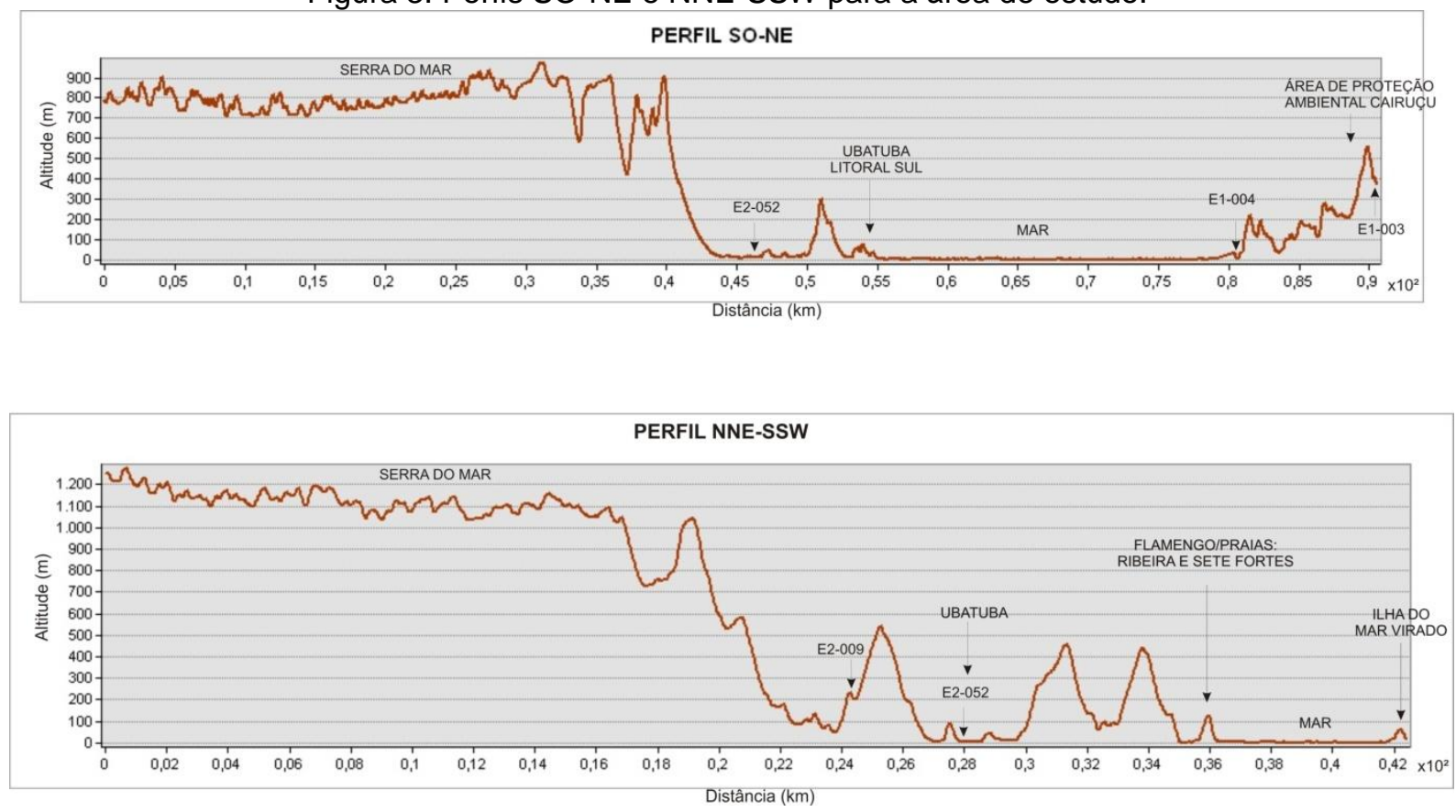

Elaboração: Santos e Baratto, 2019.

Ao elaborar o mapa geomorfológico do estado de São Paulo, Ross e Moroz (1996) basearam-se nos conceitos de Morfoestrutura ${ }^{4}$, Morfoescultura ${ }^{5}$ e taxonomia das formas de relevo ${ }^{6}$. De acordo com essa metodologia, a área de estudo pode ser assim classificada, geomorfologicamente (figura 4):

\footnotetext{
${ }^{4}$ São "(...) extensões menores [da crosta terrestre] estando representadas por determinadas características estruturais, litológicas e geotectônicas que evidentemente estão associadas as suas gêneses." (ROSS; MOROZ, 1996, p.44). Exemplos: crátons, bacias sedimentares e cinturões orogênicos.

${ }^{5}$ Conceito de "produtos morfológicos de influência climática atual e pretérita. (...) são representadas pelo modelado ou morfologias ou tipologias de formas geradas (...) através do desgaste erosivo promovido por ambiente climáticos diferenciados tanto no tempo quanto no espaço." (ROSS; MOROZ, op. cit.). Exemplos: planaltos, depressões e serras.

6 "(...) representadas por diferentes padrões de formas que face suas características de rugosidade topográfica são extremamente semelhantes entre si, quanto as altimetrias dos topos, dominância de declividades das vertentes, morfologias dos topos e vertentes, dimensões interfluviais e entalhamento dos canais de drenagem." (ROSS; MOROZ, 1996, p.45).
} 
Figura 4: Classificação geomorfológica para a área de estudo.

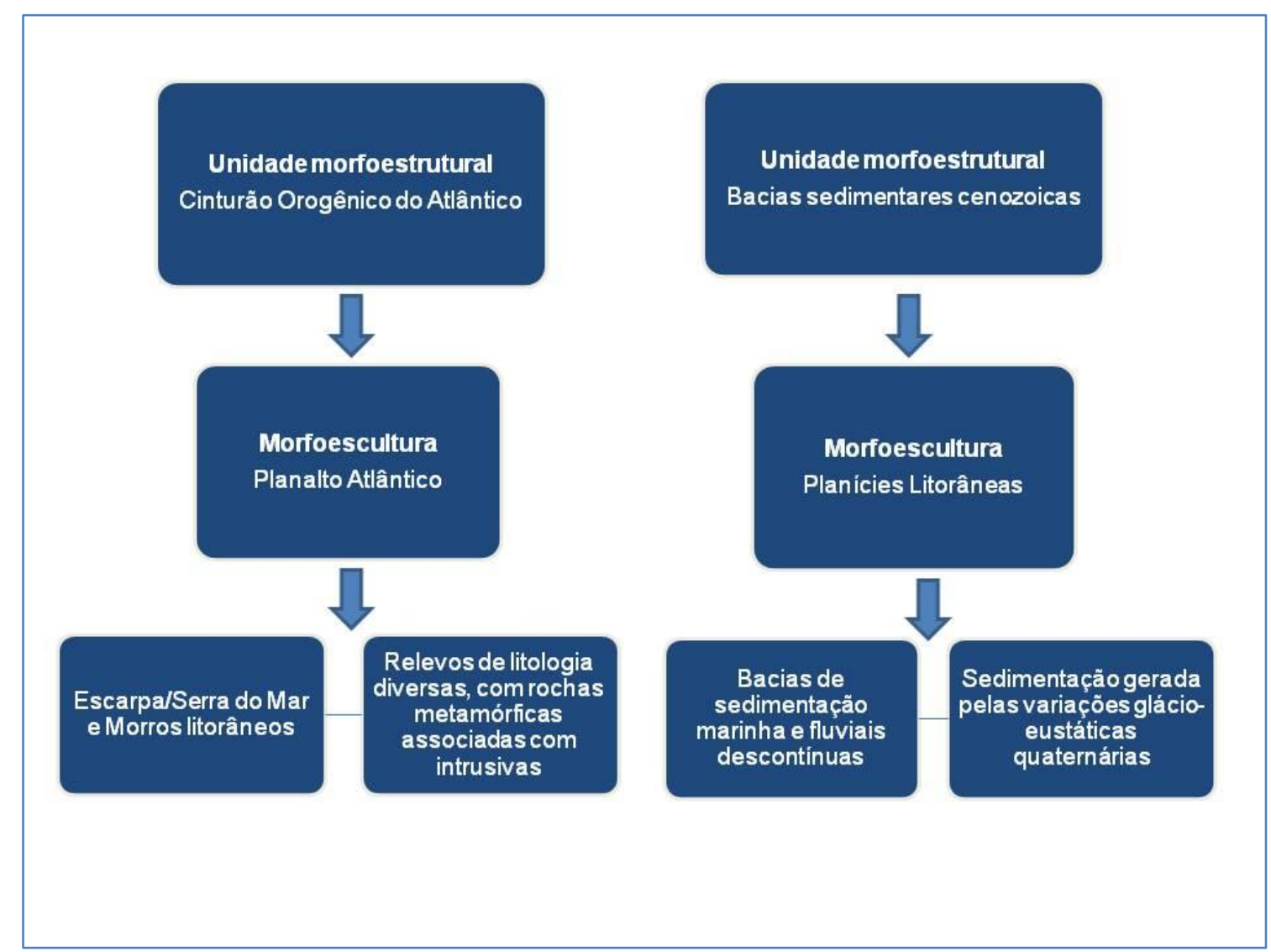

Fonte: Ross e Moroz, 1996. Org.: Santos, 2018.

Nas planícies litorâneas, os depósitos são de origem da Formação Cananéia, referentes ao pleistoceno, e os cordões litorâneos de origem mais recente. São mais relevantes no litoral sul, "limitando-se as planícies relativamente embutidas (como a de Caraguatatuba) no litoral norte." (ROSS; MOROZ, 1996, p.54).

De acordo com o Plano de Manejo do Parque Estadual da Serra do Mar (IF/SMA, 2006), a área de estudo está inserida em dois domínios geomorfológicos, a saber:

a) O Domínio das Escarpas caracteriza-se por uma faixa de encostas com vertentes com altas declividades que estão à margem do Planalto Atlântico, com orientação nordeste-sudoeste, que vai da região do Planalto da Bocaina, na divisa com o Estado do Rio de Janeiro, até o Vale do Ribeira de Iguape.

b) O Domínio das Planícies Litorâneas é presente em todo o litoral da área de estudo. A porção litorânea correspondente a este domínio constitui-se no espaço onde ocorrem processos geomorfológicos tanto de origem marinha quanto continental, e suas interações com a atmosfera e com as ações antrópicas. 


\subsubsection{Climatologia}

Ao estudar os climas do estado de São Paulo, Setzer (1946) afirma que a variedade de tipos climáticos na região está presente porque a mesma, em primeiro lugar, está em uma área de transição de climas tropicais para subtropicais. Em segundo lugar, "as variações de altitudes de tipos fisiográficos (...) condicionam diferenças de temperatura e retém pelas suas serras, ou afugenta pelos seus vales superaquecidos, as chuvas que caminham segundo direções prediletas." (p.35).

Diferentemente da configuração do Litoral Sul, ao norte a Serra do Mar se faz presente muito próxima ao litoral. A exceção é o "bolsão formado pela enseada de Caraguatatuba, que se assemelha a um imenso anfiteatro e chega a atingir cerca de 10 km de largura" (SANT'ANNA NETO, 1990, p.19). Esta estrutura de relevo proporciona a formação do efeito de chuva orográfica e influencia na penetração da Frente Polar Atlântica (FPA) no município. Devido à latitude, o clima é influenciado pelas massas tropicais, com chuvas intensas durante o verão e sem estação seca, mesmo durante o inverno. O LNP, assim como toda a zona costeira do estado de São Paulo, destaca-se pela sua importância natural e paisagística (SILVA et al., 2005), que é resultado dos fatores latitude, elevada umidade do oceano, sazonalidade e relevo.

Silva et al. (2005) destacam que no LNP não há uma estação seca definida; durante a primavera e o verão, os totais pluviométricos podem ultrapassar os 2000 $\mathrm{mm}$, no inverno e outono esse valor fica próximo aos $500 \mathrm{~mm}$, comprovando que há somente uma diminuição nos totais de precipitação durante estas estações. Como exemplo, a figura 5 apresenta o climograma para o município de Ubatuba e a tabela 1 expõe os dados climatológicos dos municípios na qual a área de estudo está inserida, de acordo com a classificação de Köppen. Estes resultados coincidem com os encontrados por Alvarez et al. (2018), onde o clima do tipo Af foi mapeado em quase todo litoral do estado de São Paulo, nas áreas de planícies costeiras com altitudes inferiores a 150 metros, sendo a localidade de maior altitude onde este tipo de clima ocorre na América do Sul. 
Figura 5: Climograma para o município de Ubatuba (Normal Climatológica 1961-1990).

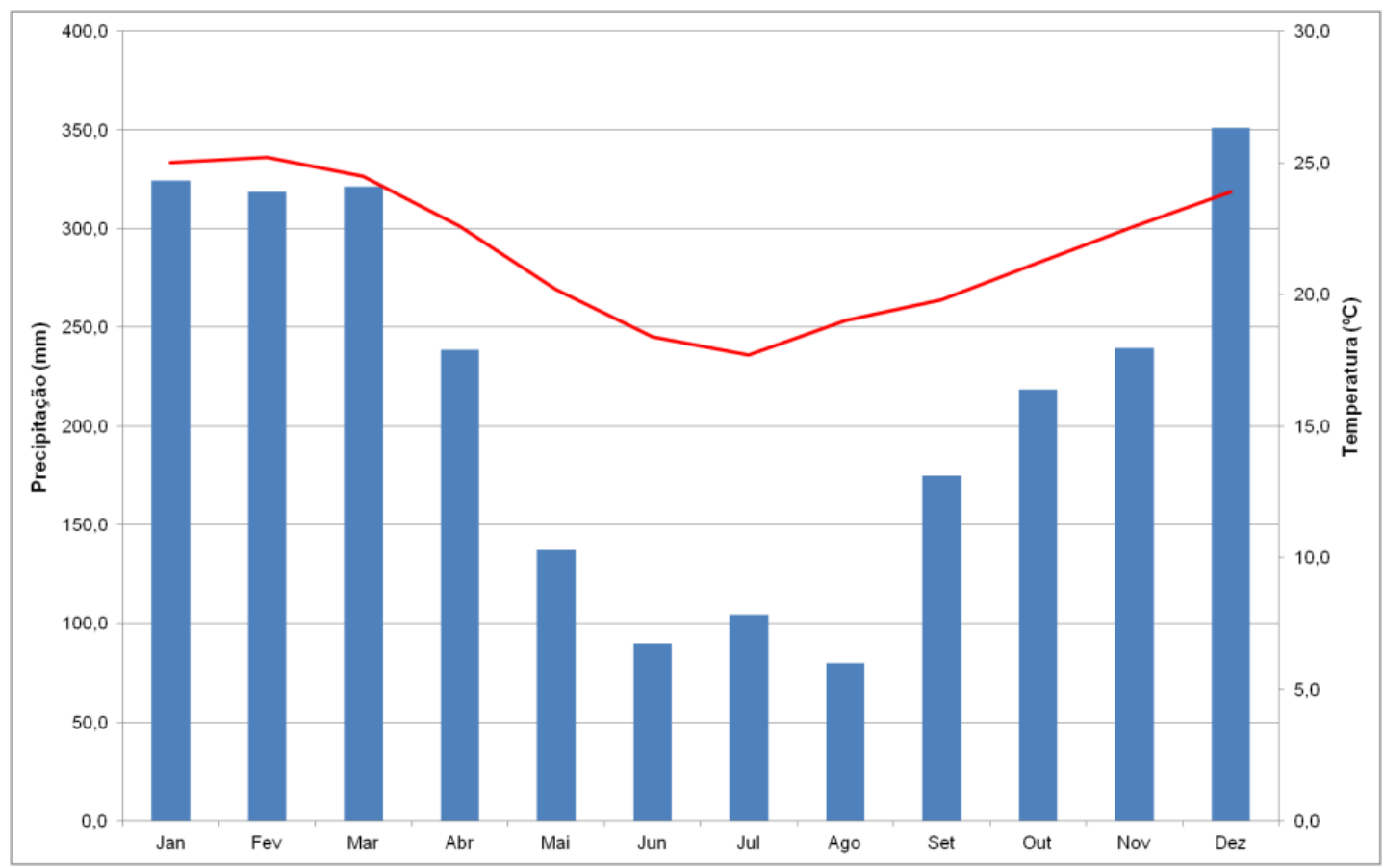

Fonte: INMET, 2018. Org: Santos, 2018.

Tabela 1: Classificação climática de Köppen para os municípios da área de estudo.

\begin{tabular}{c|c|c|c|c} 
Município & $\begin{array}{c}\mathbf{T}_{\text {max média }} \\
\left({ }^{\circ} \mathbf{C}\right)\end{array}$ & $\begin{array}{c}\mathbf{T}_{\text {min média }} \\
\left({ }^{\circ} \mathbf{C}\right)\end{array}$ & $\begin{array}{c}\text { Precipitação média anual } \\
(\mathbf{m m})\end{array}$ & $\begin{array}{c}\text { Classificação } \\
\text { Köppen }\end{array}$ \\
\hline Caraguatatuba & 31,6 & 18,2 & 1757,9 & $\mathrm{Af}$ \\
\hline Ubatuba & 27,3 & 17,8 & 2154,2 & $\mathrm{Af}$
\end{tabular}

Fonte: CEPAGRI, 2018. Org.: Santos, 2018.

$\mathrm{Na}$ classificação de Köppen, a letra maiúscula representa as regiões dos climas zonais; a subdivisão (com a primeira letra minúscula) representa a distribuição sazonal da precipitação e a segunda letra minúscula (que não se aplica a esta área) refere-se às características adicionais de temperatura. Para os municípios da área de estudo, há o predomínio o tipo Af. A letra "A" representa que o mês mais frio possui temperaturas médias superiores a $18^{\circ} \mathrm{C}$; já a letra "f" mostra que não há estação seca. Os demais municípios do LNP (Ilhabela e São Sebastião) recebem classificação diferenciada $(\mathrm{Am})$, onde a letra "m" define a localidade com clima de monção, onde há uma breve estação seca e chuvas intensas durante o restante do ano (MENDONÇA; DANNI-OLIVEIRA, 2007). Isso confirma que, por tratar-se de uma área transicional, climaticamente o Litoral Norte não é homogêneo. 
A figura 6 apresenta os balanços hídricos para cada município e corrobora com a classificação descrita acima.

Figura 6: Extrato do balanço hídrico dos municípios da área de estudo (DEF são as deficiências hídricas e EXC são os excedentes hídricos).

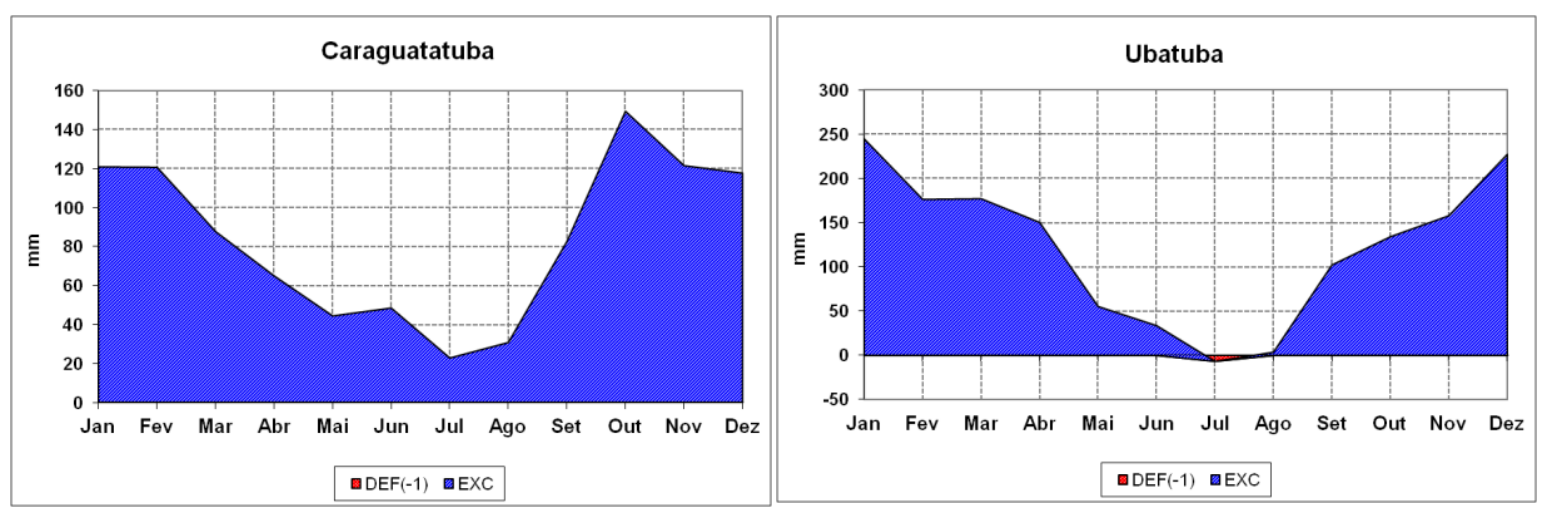

Fonte: Sentelhas et al., 1999.

A presença da Serra do Mar é de extrema importância para a compreensão da climatologia do LNP. Sua presença é responsável pelo desenvolvimento das precipitações orográficas e pelo deslocamento de sistemas atmosféricos que chegam à região. Nas vertentes da Serra do Mar, o efeito orográfico provoca acentuado aumento da pluviosidade, superando $3000 \mathrm{~mm}$, além de se posicionarem em direção conflitante às correntes atmosféricas de sul e sudeste (MILANESI, 2007; PELEGATTI, 2007).

Além da importância do relevo, o oceano também atua como controle do clima. Além de fornecer umidade que propicia a formação das nuvens, que se deslocam para a serra e forma a precipitação orográfica, o Oceano Atlântico é responsável na formação de sistema atmosféricos atuantes na região. Ao realizar um resgate de estudos sobre a variabilidade climática, Silva e Silva (2012) demonstram a importância de se correlacionar os processos que acontecem na atmosfera e nos oceanos para a compreensão das variáveis do clima, suas frequências e seus extremos. A capacidade térmica da água e os processos físicos que ocorrem na atmosfera podem ser associados à variabilidade climática e aspectos dos oceanos. A temperatura da superfície do mar (TSM) também é atributo que age na concepção e deslocamento dos sistemas, podendo ser caracterizada como um agende modelador do clima (SILVA; SILVA, 2012). 


\subsubsection{Pedologia}

A região do LNP possui solos que se diferenciam em função do compartimento da paisagem em que se encontram. De maneira geral, pode-se dizer que os solos são mais rasos na região da escarpa sobre granitos, principalmente nas altas e médias vertentes, pouco profundos a profundos no planalto sobre gnaisses e mais profundos na planície litorânea sobre sedimentos predominantemente marinhos e fluviais. Na tabela 2 encontra-se a classificação dos solos da área de estudo eleita para esta pesquisa. A composição é, em geral, caracterizada por cambissolos, espodossolos, gleissolos, neossolos litólicos e quartzarênicos e suas associações (ROSSI, 2017). Todos são classificados como distróficos ${ }^{7}$, ou seja, de média a baixa fertilidade, pois são solos ácidos.

Tabela 2: Classificação dos solos da área de estudo.

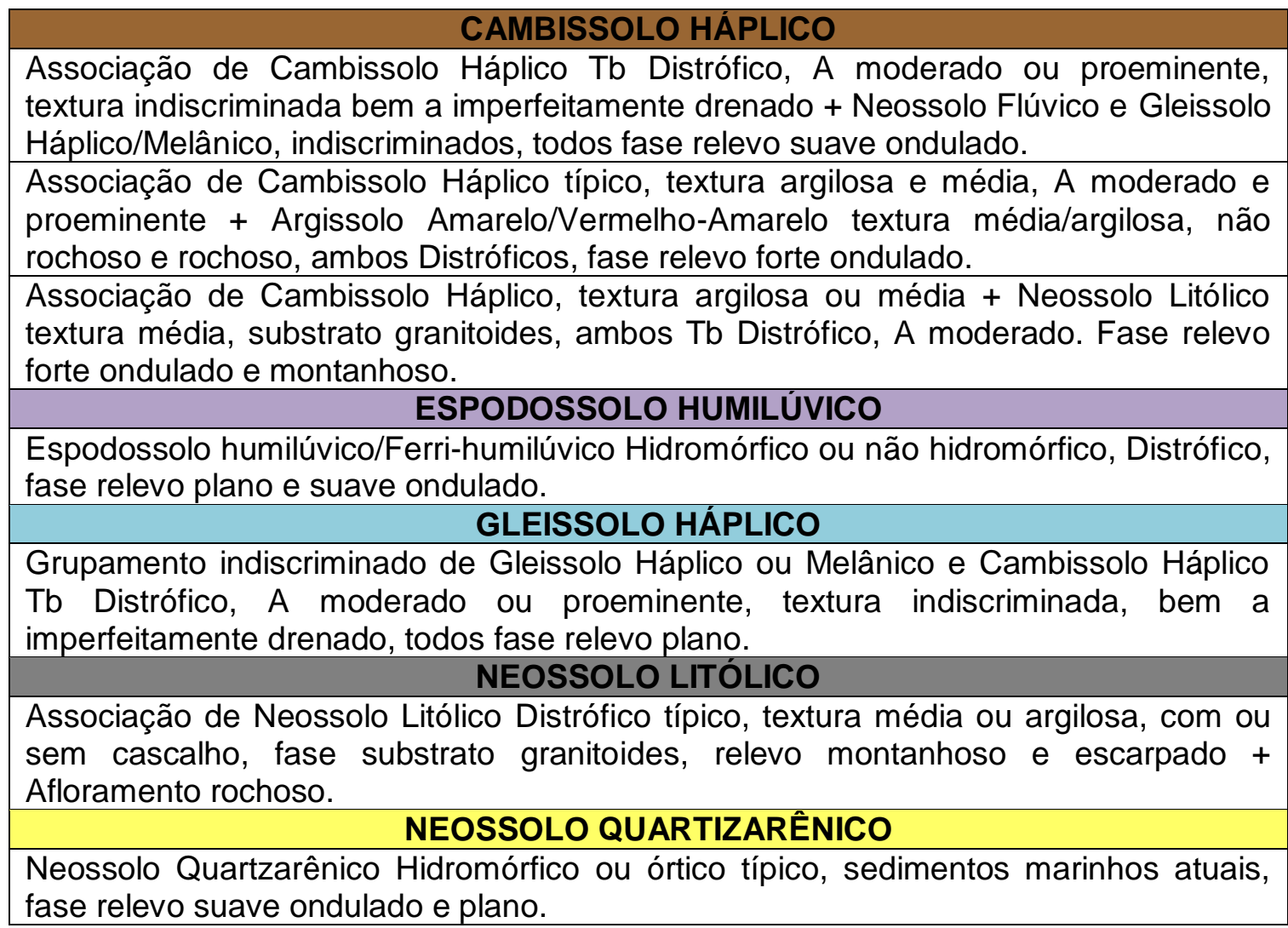
Fonte: Rossi, 2017. Org.: Santos, 2018.

\footnotetext{
7 "Refere-se à proporção de cátions básicos trocáveis (taxa percentual, V\%=100.S/T) em relação à capacidade de troca determinada a $\mathrm{pH} 7$. A expressão alta saturação se aplica a solos com saturação por bases igual ou superior a $50 \%$ (Eutrófico) e baixa saturação para valores inferiores a $50 \%$ (Distrófico). Esta característica está relacionada diretamente à fertilidade natural do solo onde os atributos Eutrófico (alta fertilidade) e Distrófico (baixa fertilidade) indicam a necessidade ou não de adubação para uso agrícola." (EMBRAPA, 2017).
} 


\subsubsection{Cobertura Vegetal}

A unidade paisagística da Serra do Mar, presente na área de estudo, é revestida pela vegetação de Mata Tropical Atlântica (atualmente renomeada de Floresta Ombrófila Densa), reflexo do clima quente e úmido da região, reforçada pela umidade do oceano, integrando o Domínio de Mares de Morros, na classificação de AB'Sáber (TITARELLI, 1986). Parte desta vegetação compõe o Parque Estadual da Serra do Mar (PESM). Na área de estudo estão presentes dois núcleos do PESM: Caraguatatuba e Picinguaba. A criação do parque estadual foi um marco na história da preservação da Mata Atlântica na região. Jequitibás (Cariniana estrellensis), canelas (Cinnamomum zeylanicum), cedros (Cedrela fissilis), jatobás (Hymenaea courbari), ipês (gênero Tabebuia e suas variações), guapuruvus (Schizolobium parahyba) e manacás-da-serra (Tibouchina mutabilis) são algumas das espécies da flora que caracterizam a riqueza da floresta perene úmida de encosta. O parque abriga e mantém inúmeras nascentes que formam os riachos e córregos que são parte de importantes bacias hidrográficas, como as dos rios Pardo, Guaxinduba e Claro. O local é aberto para visitação, possui trilhas e cachoeiras que podem ser percorridas com guias do parque.

No Litoral Norte, os esporões serranos, os pequenos maciços e os morros litorâneos isolados estão intercalados por pequenas planícies e enseadas, que formam praias de bolso (SOUZA, 2012). As planícies são constituídas por deposição fluvial e lacustre, que contém, em parte, material proveniente de rastejos e escoamento superficial das serras costeiras (origem continental). Há ainda trechos de deposição marinha, na qual foram formadas as restingas (origem oceânica). Esses sedimentos foram depositados e retrabalhados a partir das regressões marinhas do período Pleistocênico Superior e, principalmente, do Holocênico (FURLAN, 1996). Deste modo, a ocupação vegetal das planícies litorâneas é bastante recente quando comparada à floresta de encosta, num lento processo de sucessão no qual os estágios seriais determinam diferentes fitofisionomias em função de características ambientais atuais e pretéritas. A vegetação ocorre em diferentes substratos sedimentares, porém sempre associada a fatores limitantes, como alta salinidade, oligotrofia, instabilidade de solo e forte influência hídrica. Assim, quanto mais próxima da encosta, encontra-se uma floresta alta, com árvores de 10 a 15 metros de altura, instaladas sobre os aluviões provenientes das serras ou 
em terraços fluviais, reconhecidos pelo relevo plano e ligeiramente mais elevado do que os arredores. Essa formação é popularmente conhecida como Floresta Alta de Restinga (SMA/IF, 2006). A figura 7 apresenta a cobertura e uso da terra para a área de estudo.

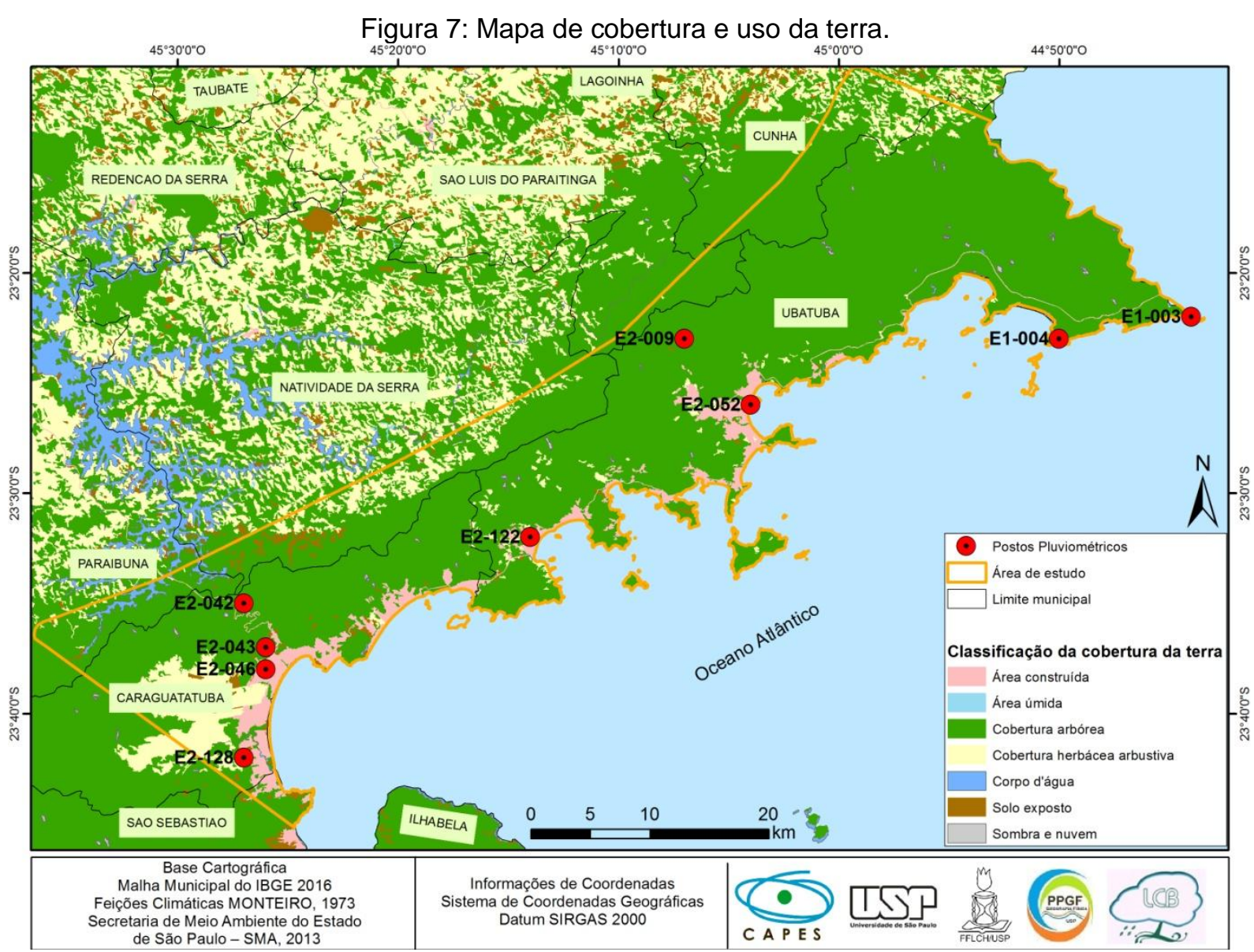

Org: Santos e Baratto, 2019.

Ainda, de acordo com a Secretaria do Meio Ambiente (SMA/IF, 2006), na região em que a área de estudo está inserida encontram-se três tipos de formações vegetativas: Floresta Ombrófila Densa Montana, Floresta Ombrófila Densa Submontana, Floresta Ombrófila Densa de Terras Baixas, além das suas respectivas vegetações secundárias: vegetação secundária da Floresta Ombrófila Densa Alto Montana, vegetação secundária da Floresta Ombrófila Densa Submontana e formações arbórea/arbustiva-herbáceas de terrenos marinhos lodosos. A Floresta Ombrófila Densa Montana é uma floresta perenifólia que se inicia na crista da Serra do Mar e estende-se para o interior do Planalto Atlântico. Situa-se entre as Florestas Estacionais Semideciduais, típicas do interior do Estado, e as Florestas Ombrófilas que recobrem a Serrania Costeira. O gradiente entre uma ou outra formação 
depende das variações na precipitação e substrato. A Floresta Ombrófila Densa Submontana está presente na encosta da Serra do Mar e nos morros isolados, que surgem na planície litorânea ou no oceano. São florestas perenes e estão sujeitas a uma pluviosidade e umidade relativa do ar mais elevada quando comparada às florestas sempre verdes do Planalto Atlântico. Já a Floresta Ombrófila Densa de Terras Baixas forma-se nas planícies litorâneas, que se desenvolvem de modo descontínuo, subordinadas às reentrâncias do fronte serrano.

\subsection{Características socioeconômicas}

A área de estudo está inserida nos municípios de Caraguatatuba e Ubatuba. A tabela 3 mostra informações demográficas em cada município, segundo o Instituto Brasileiro de Geografia e Estatística (IBGE, 2018).

Tabela 3: Dados de área, população e densidade demográfica dos municípios da área de estudo.

\begin{tabular}{c|c|c|c} 
Município & Área $\mathbf{( k m}^{2}$ ) & População (hab.) & $\begin{array}{c}\mathbf{8} \\
\text { Densidade } \\
\text { demográfica (hab/km²) }\end{array}$ \\
\hline Caraguatatuba & 484,947 & 119.625 & 207,88 \\
\hline Ubatuba & 708,105 & 89.747 & 108,87
\end{tabular}

Fonte: IBGE, 2018. Org: Santos, 2018.

A área urbana nos municípios da área de estudo, até meados da década de 1970 e 1980, possuía caráter dispersivo e de descontinuidade (a concentração urbana não era uniforme), apesar de suas condições naturais se apresentarem relativamente homogêneas (SILVA, 1975). Este fato se justifica pela sua posição periférica perante as regiões vizinhas (Vale do Paraíba, Região Metropolitana de São Paulo e da Baixada Santista e a cidade do Rio de Janeiro), que possuem índices maiores de desenvolvimento urbano, industrial e econômico.

Os municípios do LNP têm suas origens no passado colonial, inicialmente com a fundação de vilas que anos mais tarde foram elevadas à condição de municípios. A Paróquia Matriz Santo Antônio, em Caraguatatuba e as Ruínas da Lagoinha, em Ubatuba, são exemplos de patrimônios históricos construídos que tiveram sua origem no período colonial (ARRUDA et al, 2017) e, mesmo com restaurações (como é o caso da Paróquia Matriz em Caraguatatuba), ainda carregam vestígios e características de sua edificação original.

\footnotetext{
${ }^{8}$ População estimada em 2018. Fonte: Fonte: IBGE. Diretoria de Pesquisas - DPE - Coordenação de População e Indicadores Sociais - COPIS.
} 
A partir dos anos 1970, com a construção da rodovia Rio-Santos, intensificouse o turismo no LNP. Nos centros urbanos da região cresceram os investimentos comerciais, que aceleraram o processo de urbanização do litoral a partir da valorização do mercado imobiliário, formaram-se balneários, condomínios fechados e loteamentos, e assim os sítios urbanos se expandiram a partir das últimas duas décadas do século XX. O turismo tornou-se a principal atividade econômica do LNP e o recurso paisagístico passou a ser o maior produto econômico da região, principalmente no município de Caraguatatuba.

Segundo Silva (1975), o município de Caraguatatuba, diferentemente das demais cidades do LNP, sempre esteve mais favorável à urbanização, pois se encontra nas planícies costeiras de sedimentação predominantemente marinha. As escarpas das Serra do Mar são fatores condicionantes para o desenvolvimento das unidades urbanas, desde os bairros de tradições caiçaras até os balneários. O desenvolvimento do turismo e as atividades que aproveitam as praias e os recursos do mar contribuíram para a estruturação do sítio urbano caraguatatubense. Este fato proporciona a cidade o status de "capital regional" de acordo com sua urbanização. 


\section{FUNDAMENTAÇÃO TEÓRICA}

\subsection{Precipitação pluviométrica: conceitos e técnicas de análise}

Os estudos sobre precipitação, variabilidade climática e eventos extremos estão sempre presentes na literatura ligados à temática da Climatologia, Meteorologia, Meio Ambiente, entre outros. Estes trabalhos, quando relacionados ao meio tropical, possuem extrema relevância, dado que as características físicas destas regiões são determinantes na ocorrência de desastres naturais atrelados aos eventos extremos de chuvas. Riehl (1965) afirma que a variação da precipitação nos trópicos é maior nos meses com menor média de precipitação e decresce à medida que esta aumenta e a variabilidade relativa é "a razão entre a média aritmética dos valores modulares dos desvios e o valor da média das precipitações (...). A variabilidade relativa é baixa onde a precipitação é alta e é alta onde a precipitação é baixa." (p.97).

Ayoade (2004) define que, para a Meteorologia, a precipitação é um termo utilizado para qualquer deposição em forma líquida ou sólida que são derivadas da atmosfera. Porém, na região dos trópicos, somente a chuva contribui com valores significativos e é denominada como "precipitação" ou "precipitação pluvial". A pluviometria é caracterizada como a quantificação das precipitações pluviais (pluvio = chuva); a unidade de medida adotada é o milímetro $(\mathrm{mm})$, significando a precipitação de um litro de água por metro quadrado de superfície (VAREJÃOSILVA, 2006). Tubelis e Nascimento (1984) consideram que a precipitação é o processo pelo qual a água condensada na atmosfera atinge gravitacionalmente a superfície terrestre.

A formação da precipitação está inserida como parte do ciclo da água, resultante da interação da superfície terrestre com a atmosfera, que envolve a evapotranspiração e a condensação, resultando em nuvens que podem gerar chuvas. A evapotranspiração é o processo em que a água, na sua forma líquida, ascende e passa para a forma gasosa, ou seja, vapor d'água. A condensação ocorre quando este vapor transforma-se em água líquida, podendo ocorrer quando o ar se resfria até o seu ponto de orvalho (sem ocorrer mudança de volume), quando o volume de ar aumenta sem variação de calor por expansão adiabática e quando a variação de temperatura e volume do ar faz com que o mesmo reduza sua 
capacidade de retenção de umidade. Na atmosfera, o resfriamento é o processo mais comum que atinge a saturação do ar e, por consequência, a condensação. A formação de nebulosidade pode ocorrer com a movimentação vertical de ar úmido (convecção), na ascensão forçada sobre o relevo ou nos movimentos verticais de grande escala (como em frentes frias) (BARRY; CHORLEY, 2003; AYOADE, 2004).

Diversas teorias sobre a formação de nuvens e precipitações foram discutidas ao longo dos estudos em meteorologia. Atualmente, duas destas teorias são aceitas pela comunidade científica: a Teoria Bergeron-Findeisen e a Teoria da Coalescência. A primeira defende que o resfriamento do vapor d'água em ascensão forma cristais de gelo, estes, ao ficarem maiores com a união de gotas d'água, tornam-se pesados para se manterem na nuvem e caem. Com isso, se encontram ar mais quente podem precipitar em forma de gotas (água líquida). Porém, esta teoria não é aplicável ao processo de formação de precipitação em área tropical, visto que há a ocorrência de nuvens quentes. Nestas regiões ocorre o que é descrito pela Teoria da Coalescência, onde as gotas de água maiores caem das nuvens com maior rapidez que as gotas pequenas, absorvendo as menores no percurso (BARRY; CHORLEY, 2003; AYOADE, 2004).

Os dados de precipitação máxima (principalmente horária) são importantes para a orientação de obras de infraestrutura nas cidades e terras cultivadas no meio rural. Entretanto, estes dados só possuem valor quando há o estudo de dezenas de anos de observação (SETZER, 1946). Em seu estudo para o estado de São Paulo, o autor encontrou na zona costeira os maiores totais anuais de precipitação do estado, com a estação do outono sendo $25 \%$ mais chuvosa que a primavera.

Cruz (1974) desenvolve seu trabalho na área da Geomorfologia em Caraguatatuba (SP), destacando alguns episódios de chuvas no final do ano de 1966 e início de 1967 que desencadearam os deslizamentos na Serra do Mar, com chuvas associadas às passagens da Frente Polar Atlântica. Segundo a autora, as precipitações intensas são capazes de criar momentos especiais na morfogênese: "Como é de fato conhecido, não são as situações normais, mas sim as excepcionais que fazem evoluir a paisagem" (p.165).

Em seu estudo sobre a gênese das chuvas no setor lesnordeste do estado de São Paulo, Conti (1975) considera que a variação da pluviosidade depende da atuação dos fluxos atmosféricos. O autor destaca, contudo, que o mecanismo da gênese das chuvas é complexo e que o relevo não deve ser ignorado, sobretudo nas 
regiões do globo onde os valores altimétricos são expressivos. A região é importante para estudos climatológicos também pela configuração da dinâmica atmosférica regional: encontra-se em uma área de transição, onde, mesmo com a diminuição das precipitações em função da latitude, os eventos ocorrem com grande influência da ação das frentes.

Sant'anna Neto (1990) buscou caracterizar a gênese das chuvas na zona costeira paulista, com sua distribuição espacial e temporal, considerando seu ritmo e eventos de excepcionalidade, classificando as séries históricas em anos-padrão. O autor procurou também discutir a classificação tipológica para a zona costeira, com base na obra de Monteiro (1973) e desenvolver modelos de representações do fenômeno pluvial, através da confecção de cartas síntese e gráficos de análise rítmica.

A fim de determinar a variabilidade da concentração da precipitação diária e mensal para o sudeste brasileiro, Nery et al. (2017) aplicaram a metodologia do índice de concentração diária e interanual. Segundo os autores, "o índice de concentração de precipitação (ICP) foi utilizado para avaliar a sazonalidade da precipitação e o índice de concentração (IC) foi utilizado para avaliar o peso dos maiores eventos diários em relação à quantidade total de precipitação." ${ }^{9}$ (p.187). Os resultados mostraram que a maior porcentagem da precipitação é referente ao quartil mais alto dos dias chuvosos e que a variabilidade diária de precipitação dentro de um ano pode ser explicada pela porcentagem de precipitação que contribuiu com $50 \%$ dos dias chuvosos na área de estudo.

Para estudar a variação diurna e horária das precipitações na Malásia, Varikoden et al. (2011) utilizaram uma serie de dados de onze anos (1998 a 2009) onde classificaram a frequência das chuvas em reduzida $\left(R^{10}<4 \mathrm{~mm} / \mathrm{h}\right)$, moderada $(4<R<8 \mathrm{~mm} / \mathrm{h})$, alta $(8<R<12 \mathrm{~mm} / \mathrm{h})$ e muito alta $(R>12 \mathrm{~mm} / \mathrm{h})$ intensidade, para cada período do ano (pré-monção, monção e pós monção). Os valores foram calculados em porcentagem e foram utilizados para a espacialização dos dados em mapas temáticos. O uso desta metodologia foi possível pela disponibilidade de dados de chuva obtidos em escala horária. Para esta pesquisa de mestrado, esta possibilidade não é aplicável visto que há apenas dados diários de precipitação.

\footnotetext{
${ }^{9}$ Tradução livre da autora.

${ }^{10} \mathrm{R}=$ rainfall (chuva ou precipitação, em inglês).
} 
No estudo da variabilidade espacial e temporal das precipitações no Mato Grosso do Sul, Teodoro et al. (2015) aplicaram o algoritmo de Ward. Na análise de agrupamento, puderam identificar cinco regiões homogêneas, de acordo com os períodos definidos como chuvosos, de transição e seca. As cinco regiões homogêneas foram classificadas de acordo com a predominância do bioma local (Cerrado, Mata Atlântica e Pantanal) e dos sistemas sinóticos que exercem influência na região. Os mapas de distribuição da precipitação foram elaborados utilizando o método de interpolação de dados.

Para a região norte de Bangladesh, Bari et al.(2016) trabalharam com a análise de tendência para avaliar a distribuição anual e sazonal das precipitações. $O$ estudo confirmou que as chuvas de monções estão diminuindo não significativamente na maior parte do norte de Bangladesh; em contrapartida, as precipitações pré-monção e pós-monção mostra uma não significativa (no limite de confiança de 95\%) tendência crescente na maior parte da área de estudo. O teste de Mann-Kendall sequencial foi aplicado e revela flutuações periódicas para chuvas sazonais na maioria das estações e a tendência decrescente das chuvas sazonais foi encontrada após o início de 1990 na maioria das estações.

Bachir et al. (2016) realizaram uma caracterização das precipitações anuais com uma representação temporal e espacial para a Argélia. A análise baseou-se na geoestatística, regressão linear múltipla e relação direta entre a precipitação e parâmetros geográficos (longitude, latitude e altitude). Para os autores, os testes indicaram que a latitude é o parâmetro mais influente com um coeficiente de 261,25, contrário à longitude e altitude (17,06 e 0,04, respectivamente), que têm um efeito não significativo na precipitação. Além disso, outros fatores, como a vegetação, a temperatura e o deslocamento das massas de ar em nível regional afetaram negativamente a gênese chuvas (com redução das precipitações).

Jongjin et al. (2016) fizeram uso de três técnicas estatísticas diferentes combinadas com dados de estimativa de precipitação de satélite meteorológico e dados de estações terrestres para estimar a distribuição espacial da precipitação, na jusante da bacia do Rio Namhan, Coreia do Sul. Os resultados permitiram afirmar que estimativas de precipitação quase em tempo real podem ser produzidas utilizando técnicas que conciliam a baixa densidade de pluviômetros e eventos de chuva espacialmente heterogêneos. Considerando a tendência de maior espacialização heterogênea das precipitações, a combinação de diversas técnicas 
podem potencialmente proporcionar importantes ganhos de habilidade na previsão de desastres naturais como inundações e escorregamentos.

\subsection{Escalas de abordagem em Climatologia Geográfica}

A definição da escala de abordagem nos estudos climáticos faz-se necessária em todos os momentos da pesquisa, desde a definição da área de estudo, fontes e tipos de dados (primários e/ou secundários), necessidade de trabalhos de campo e necessidade de compreender a extensão e duração dos fenômenos climatológicos. Ribeiro (1993) propõe taxonomias de acordo com a variação espaço-temporal e estabelece critérios, como:

a) São consideradas escalas superiores àquelas mais próximas do nível planetário e escalas inferiores àquelas mais próximas dos indivíduos habitantes da superfície da Terra;

b) As combinações de processos físicos interativos numa escala superior resultam em modificações sucessivas no comportamento da atmosfera nas escalas inferiores;

(RIBEIRO, 1993, p. 288).

O clima zonal é a maior unidade de escala climática, que abrange áreas extensas do planeta Terra (o planeta por completo, faixas ou zonas). É influenciado por fatores como a latitude, altitude, maritimidade, continentalidade e a distância e posição relativa Terra-Sol. No clima zonal há a atuação da circulação geral da atmosfera: Zona de Convergência Intertropical (ZCIT), alíseos, anomalias relacionados ao El Niño e a La Niña, entre outros. Para as análises climatológicas a nível zonal, são necessários registros de no mínimo 30 anos, principalmente em relação ao deslocamento dos sistemas que envolvem as variações de pressão atmosférica, ventos, precipitação, radiação solar e temperatura (RIBEIRO, 1993).

O clima regional está inserido no clima zonal como uma variação da circulação geral da atmosfera em resultado de elementos como distribuição de terras emersas e oceano e rugosidade dos continentes. De acordo com o autor

As perturbações na circulação primária, provocadas pela influência dos mencionados fatores, geram perturbações sinóticas que criam os centros de ação, intermediários entre a circulação primária e secundária: massas de ar e frentes que se revelam através de sistemas de circulação atmosférica. A extensão, a permanência e a frequência da atuação de grupos de sistemas de circulação atmosférica provocam o impacto necessário para produzir condições 
relativamente estáveis para o desenvolvimento de uma bio-morfopedogênese característica de uma determinada região natural. (RIBEIRO, 1993, p.290).

Para o estudo de climas regionais, as análises devem ser de ordem anual, mensal, sazonal dos atributos do clima, estabelecendo uma correlação com os fatores geográficos naturais (por exemplo, o relevo) "que provocam a definição de cada espaço regional, como elemento causal da modificação da circulação geral da atmosfera e geração do clima regional" (RIBEIRO, 1993, p.290).

Ao desenvolver os estudos para o Plano de Manejo do Parque Estadual Intervales, Serafini Júnior et al. (2012) realizaram a adequação das escalas climatológicas, assim como o proposto por Monteiro (2003). Os autores usam a escala sub-regional, visto que as escalas regional e local não abrangeriam com clareza os atributos climáticos estudados. A escala sub-regional refere-se aos limites do parque e seu entorno e considerou a pluviosidade como atributo a ser analisado, visto que ela é a que exerce maior influência na probabilidade de ocorrência de eventos extremos na região.

O Mesoclima ou clima local pode ser compreendido como aquele que sofre a interferência da variação altimétrica nos valores de temperatura e umidade do ar, por exemplo, como também a ação humana na superfície terrestre, no caso dos centros urbanos. Com isso, para estudos a nível local é necessário o conhecimento e caracterização de geomorfologia e cobertura vegetal. As análises climatológicas realizam-se com séries temporais mensais, anuais e diárias e dados de postos pluviométricos, podendo haver o auxílio de imagens de radar meteorológico (RIBEIRO, 1993).

A escala topoclimática refere-se a um recorte do clima local, considerando a variação altimétrica como importante fator na variação dos atributos climáticos, bem como a forma e orientação das vertentes. Os dados para este tipo de estudo devem ser gerados por estações não convencionais, transectos ou perfis geoecológicos (RIBEIRO, 1993). O estudo topoclimático em um perfil do PESM desenvolvido por Santos et al. (2016) permitiu o desenvolvimento de análises acerca da temperatura do ar. Os valores mínimos horários foram influenciados pelo vento e umidade originados no Oceano Atlântico e os valores diários pela aproximação e passagem de sistemas frontais. Os valores máximos receberam interferência da cobertura 
vegetal, local de instalação dos abrigos meteorológicos e possíveis variações do vento ao longo do dia.

Por fim, Ribeiro (1993) considera a escala de microclima como aquela que depende da "magnitude das trocas gasosas e energéticas entre as feições ou estruturas particularizadas" (p.293). Pequenos deslocamentos da parcela de ar, cobertura vegetal e uso do solo são alguns dos fatores que influenciam os estudos microclimáticos, que podem ser realizados em ambientes como parques urbanos, manguezais, reservatórios de água, entre outros. Para o registro dos dados de microclima, é necessário o uso de equipamentos de alta precisão que sejam capazes de registrar variações climáticas na ordem de minutos ou até segundos.

A figura 8 e a tabela 4 ilustram uma síntese das escalas do clima aqui apresentadas. É importante ressaltar que este tema não se esgota e que ainda há divergências entre autores sobre as taxonomias das escalas climáticas em relação às nomenclaturas e divisões escalares.

Figura 8: Hierarquia das escalas climatológicas.

ORGANIZAC̄ÃO HIERÁRQUICA DAS ESCALAS CLIMATOLÓGICAS

REGIONAL (A), SUB-REGIONAL (B), LOCAL (C), TOPOCLIMÁTICA (D), MICROCLIMÁTICA (E)

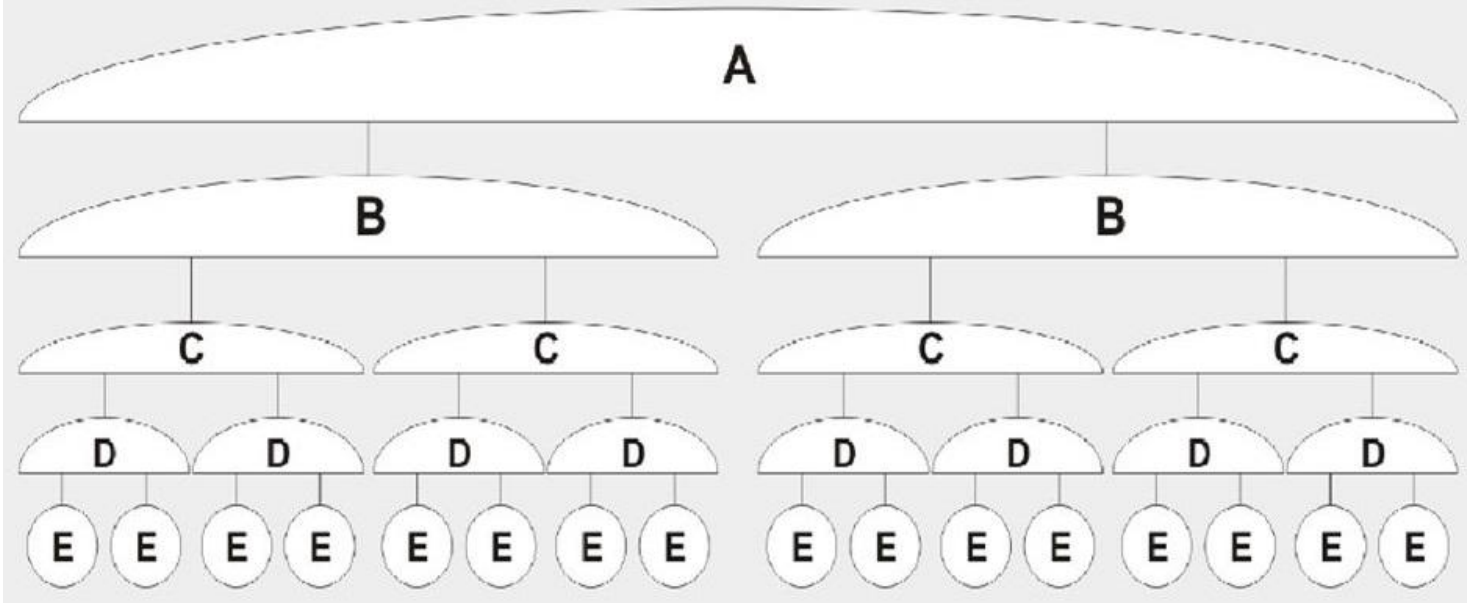

Fonte: Serafini Júnior et al., 2012, p.45. 
Tabela 4: Organização das escalas espacial e temporal do clima.

\begin{tabular}{|c|c|c|c|c|}
\hline $\begin{array}{l}\text { Ordem de } \\
\text { grandeza }\end{array}$ & $\begin{array}{l}\text { Escala } \\
\text { horizontal }\end{array}$ & $\begin{array}{l}\text { Escala } \\
\text { vertical }\end{array}$ & $\begin{array}{c}\text { Temporalidade } \\
\text { das variações } \\
\text { mais } \\
\text { representativas }\end{array}$ & $\begin{array}{c}\text { Exemplificação } \\
\text { espacial }\end{array}$ \\
\hline $\begin{array}{c}\text { Clima Zonal } \\
\text { Clima } \\
\text { Regional }\end{array}$ & $>2000 \mathrm{~km}$ & 3 a 12 km & $\begin{array}{c}\text { Algumas } \\
\text { semanas a } \\
\text { vários decênios }\end{array}$ & $\begin{array}{l}\text { O globo, um } \\
\text { hemisfério, } \\
\text { oceano, } \\
\text { continente, etc. }\end{array}$ \\
\hline $\begin{array}{l}\text { Clima Sub- } \\
\text { regional } \\
\text { Clima Local } \\
\text { Topoclima }\end{array}$ & $\begin{array}{c}2000 \mathrm{~km} \text { a } 10 \\
\mathrm{~km}\end{array}$ & $\begin{array}{c}12 \mathrm{~km} \text { a } 100 \\
\text { metros }\end{array}$ & $\begin{array}{l}\text { Várias horas a } \\
\text { alguns dias }\end{array}$ & $\begin{array}{l}\text { Região natural, } \\
\text { montanha, } \\
\text { região } \\
\text { metropolitana, } \\
\text { cidade, etc. }\end{array}$ \\
\hline Microclima & $\begin{array}{c}10 \mathrm{~km} \mathrm{a} \\
\text { alguns metros }\end{array}$ & $\begin{array}{l}\text { Abaixo de } 100 \\
\text { metros }\end{array}$ & $\begin{array}{c}\text { De minutos ao } \\
\text { dia }\end{array}$ & $\begin{array}{c}\text { Bosque, uma } \\
\text { rua, uma } \\
\text { edificação/casa, } \\
\text { etc. }\end{array}$ \\
\hline
\end{tabular}

Adaptado de: Mendonça e Danni-Oliveira, 2007.

Considerando os conceitos expostos, esta pesquisa encaixa-se na ordem de um estudo regional, sub-regional e local, pois:

a) trata da compreensão de um atributo do clima (precipitação) com sua análise anual, mensal e sazonal;

b) se utiliza de postos pluviométricos de superfície e considera o relevo como um controle geográfico de extrema importância;

c) a análise dos eventos extremos se dá de forma pontual e concebe a localização do posto pluviométrico como fator determinante.

\subsection{Feições climáticas do LNP - Monteiro, 1973}

Galvani e Lima (2012) realizaram uma revisão bibliográfica acerca dos autores que trabalharam com o objetivo de classificar e regionalizar as precipitações no estado de São Paulo. Os estudos consideraram diversos aspectos como hidrografia, paisagens geográficas, regiões ecológicas, corespondência entre precipitação e relevo, e gênese das precipitações. Para este trabalho, foi eleita a classificação de Monteiro (1973), pois a mesma realiza um recorte na área de estudo que é adequada para a escala da pesquisa proposta.

Monteiro (1973) classifica os climas paulistas demonstrando a necessidade de se adotar um caráter dinâmico e genético ao estudo do clima (figura 9). O autor divide o estado em seis áreas, levando em consideração as unidades morfológicas 
do relevo (Litoral, Planalto Atlântico, Vale do Paraíba, Mantiqueira, Depressão e Planalto Ocidental) e conclui que a área litorânea pode ser subdividida em três subunidades:

a) Litoral Norte (A1 la) - área compreendida entre São Sebastião e Ubatuba, controlada por massas tropicais, com clima úmido das encostas expostas ao Oceano Atlântico, sujeitas a uma menor participação das massas polares com cerca de $30 \%$ a $40 \%$, menos sujeita às invasões de frio e a posição da Serra do Mar bem próxima à costa é responsável pela acentuada pluviosidade mesmo no inverno (efeito orográfico). Esta foi a feição (ou unidade) climática escolhida para este estudo.

b) Litoral Central (B1 lb) - de Maresias a Itanhaém, controlado por massas tropicais e polares, de clima úmido na face oriental e subtropical com aumento da participação das massas polares onde a serra se aproxima da costa quase no sentido oeste-leste, que aliado à direção oponente às correntes perturbadas do sul, faz com que este trecho seja a área de maior pluviosidade do Brasil.

c) Litoral Sul (B1 la) - de Peruíbe a Cananéia, área controlada por massas tropicais e polares (tal qual a área B1 lb) caracterizada, porém, pela maior variação da pluviosidade já que o afastamento da Serra de Paranapiacaba da linha de costa faz alternar as planícies dos maciços isolados, com o aumento das participações das massas polares e passagens frontais e a distribuição quantitativa das chuvas varia de acordo com a topografia (SANT'ANNA NETO, 1990). 
Figura 9: Classificação Climática do Estado de São Paulo.
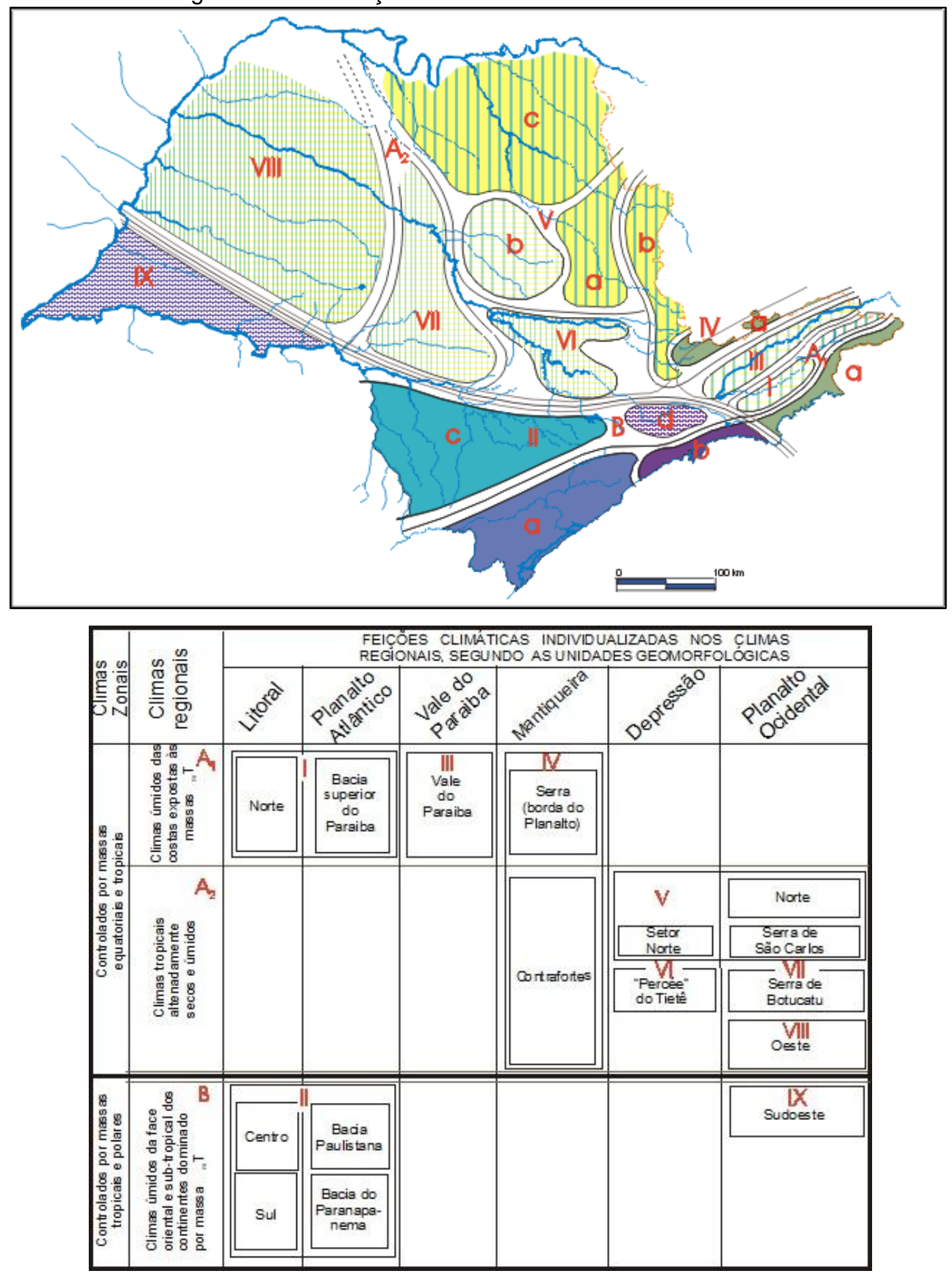

Fonte: Monteiro (1973).

A escolha por trabalhar com as feições climáticas deu-se pela necessidade de estabelecer uma área de estudo com cobertura de postos pluviométricos que possuísse longas séries históricas de dados produzidos em escala diária. A região possui importância científica climática e geomorfológica, visto que o relevo cumpre o papel de influenciar os tipos de tempo atuantes na região. 


\subsection{Controles atmosféricos no LNP}

A circulação geral da atmosfera é o conjunto de movimentos atmosféricos que, na escala planetária (circulação primária), determina as zonas climáticas; são padrões em grande escala de ventos e pressão atmosférica que se desenvolvem anual ou sazonalmente. Nos diferentes lugares do planeta, a circulação secundária define os tipos de tempo. São as depressões e anticiclones e perturbações tropicais, que podem durar alguns dias e se movem com rapidez. A circulação terciária é composta de ventos locais, como a brisa terrestre e marítima, ondas de sotavento e os ventos anabáticos e catabáticos. Ela é responsável por eventos locais e sua existência, em geral, é mais curta que os sistemas de circulação secundários (AYOADE, 2004; MENDONÇA; DANNI-OLIVEIRA, 2007).

A dinâmica atmosférica na América do Sul é influenciada pela sazonalidade, distribuição da radiação solar e extensão longitudinal do continente, além do relevo diverso, com a atuação de massas equatoriais, tropicais e polares. Na faixa tropical, especificamente no Brasil, temos a atuação de três importantes massas: tropical atlântica $(\mathrm{mTa})$, tropical continental $(\mathrm{mTc})$ e a polar atlântica $(\mathrm{mPa})$, como ilustrado na figura 10. 
Figura 10: Distribuição das massas de ar na América do Sul segundo suas fontes e deslocamentos principais.

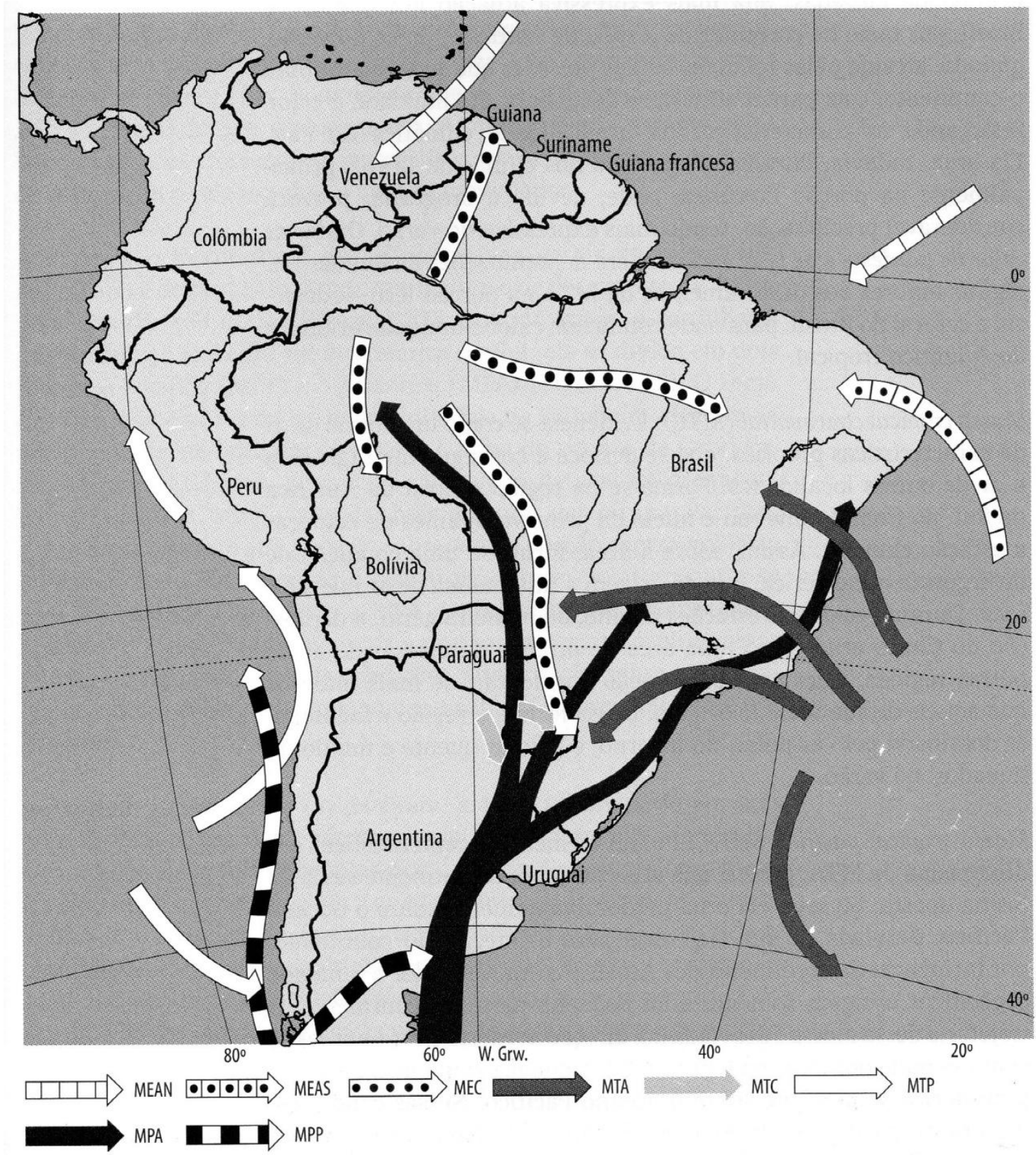

Fonte: Monteiro, 1968.

A mTa se origina no centro de altas pressões subtropicais do Oceano Atlântico, possuindo características de temperatura e umidade elevadas. Sua atuação é intensiva durante o verão, levando umidade e calor e acentuando as características de clima tropical do Brasil, principalmente nas regiões litorâneas onde a orografia também colabora na formação de precipitações A mTc se desenvolve na região central da América do Sul no final do inverno e início de primavera, formando uma área de divergência atmosférica com uma massa de ar quente e seca. No restante do ano, desloca-se à região da Depressão do Chaco atuando na atração de 
massas de ar de outras regiões; durante 0 inverno na região predomina 0 ar polar (frio e seco) e durante o verão o ar equatorial (quente e úmido) (MENDONÇA; DANNI-OLIVEIRA, 2007).

A massa polar forma-se na região do polo, com características de temperatura e umidade baixas. Quando se desloca para o norte, chegando a Cordilheira dos Andes (extremo sul da América do Sul), se divide em dois ramos originando a Massa Polar Pacífica $(\mathrm{mPp})$ e a Massa Polar Atlântica $(\mathrm{mPa})$. O deslocamento da $\mathrm{mPa}$ faz com que sua atuação se dê em toda porção centro-sulleste da América do Sul. Chegando à latitude do Rio da Prata, esta massa se subdivide em duas parcelas: uma adentra o continente pelos vales dos rios da Prata, Paraguai e Paraná, sendo responsável pelo resfriamento da temperatura e queda da umidade na região durante o inverno; e a outra segue pela região costeira, associando-se à mTc. Como consequência, ocorrem as precipitações de inverno no leste brasileiro (BORSATO; MENDONÇA, 2015).

As instabilidades atmosféricas são características da passagem de um sistema frontal sobre uma determinada região, onde há o deslocamento do ar quente em altitude que dá lugar ao ar frio (o ar frio avança mais rápido que 0 ar quente). A frontogênese relacionada à Frente Polar Atlântica (FPA) é extremamente importante na configuração climática da América do Sul e, consequentemente do Brasil. Sua atuação é destaque, em relação à intensidade e duração, durante o inverno e na primavera, com razoável diminuição no outono e verão (MENDONÇA; DANNI-OLIVEIRA, 2007).

O Sudeste brasileiro é uma área de transição de climas. Esta configuração afeta o sistema regular e de previsão das condições de tempo de curto a longo prazo na região (SANT'ANNA NETO, 2005). Esta característica também é notável na zona costeira do Estado de São Paulo. Durante o verão há a atuação das correntes de leste (resultante dos alíseos) trazidas pela $\mathrm{mTa}$, que produzem a condição de tempo estável. Ao encontrar a Serra do Mar (à barlavento), se eleva produzindo um aumento de umidade e precipitação; ao descer (à sotavento), pelo efeito adiabático, há a diminuição (ressecamento) da umidade e aumento da temperatura do ar.

Em relação às correntes de sul, a entrada do anticiclone polar atlântico produz extensas áreas de instabilidade atmosférica frontal, ao entrar em contato com as massas tropicais. O conjunto da atuação dessas correntes com a umidade fornecida pelo oceano provocam as chuvas de primavera e verão. Durante o inverno, as 
massas tropicais mais frágeis são empurradas pelo anticiclone, que avança para as latitudes mais baixas, proporcionando a evolução da massa polar. A ZCAS é responsável pelas perturbações frontais durante sua atuação no Sudeste, refletindo seus efeitos na área de estudo. Também atuam as linhas de instabilidade tropical (quando se encontram $O$ ar úmido do oceano com 0 ar seco do continente) (SANT'ANNA NETO, 2005). Aliada à atuação da ZCAS, há também a Zona de Convergência de Umidade (ZCOU), que possui aspectos similares ao primeiro sistema. A ZCOU se diferencia por atuar apenas por três dias consecutivos, ou então quando se inicia a dissipação de uma ZCAS (SACRAMENTO NETO et al., 2010).

Os Complexos Convectivos de Mesoescala (CCM) também estão presentes na gênese das precipitações da área de estudo. Estes sistemas atmosféricos, que recebem calor e umidade vindos da Amazônia por meio dos Jatos de Baixos Níveis (JBN), podem atuar em conjunto aos sistemas frontais (SF) na propagação de chuvas extremas. Os CCM têm sua origem no final da tarde e início da noite, onde as células convectivas encontram condições favoráveis para convecção, como os fatores em escala local (topografia e aquecimento da superfície) (SILVA DIAS et al., 2009). Sua duração costuma ser de 6 a 15 horas, ou seja, se desenvolvendo durante a madrugada e dissipando-se em torno do meio-dia do dia subsequente. A trajetória conhecida dos CCMs indica que sua formação se dá a leste dos Andes (principalmente na Bacia do Paraná e Paraguai), deslocando-se principalmente para a região Sul do Brasil (SILVA DIAS, 1996). De acordo com Figueiredo e Scolar (1996), do total de 25 CCMs analisados em seu estudo, $70 \%$ chegaram aos estados do Sul e $30 \%$ chegaram os estados do Sudeste brasileiro.

No LNP a circulação secundária é caracterizada pela atuação da $\mathrm{mTa}, \mathrm{mPa} e$, em menor escala, a mTc. O oceano age como fornecedor de umidade; a maritimidade, somada à atuação dos ventos alíseos do anticiclone tropical atlântico, é responsável pelas precipitações litorâneas que progressivamente diminuem no sentido leste-oeste pela continentalidade (SANT'ANNA NETO, 2005). Na área de estudo, a orientação SO-NE da Serra do Mar atua como barreira natural, sendo responsável pela formação de precipitações orográficas e atuando também no deslocamento de sistemas atmosféricos (MONTEIRO, 1973; MILANESI, 2011). A região também é palco da ação dos sistemas frontais, como a FPA, responsável por grande parte das precipitações que ocorrem no período de outono e inverno. 
Para o nordeste do estado de São Paulo, localidade onde a área deste estudo está inserida, Armani e Galvani (2011) contabilizaram a passagem de sistemas atmosféricos entre o inverno de 2008 e o outono de 2009. Neste período, a FPA esteve presente em $21,9 \%$ dos dias, com o total de 45 passagens. Os sistemas extratropicais (anticiclônicos e frontais) ocuparam $64,9 \%$ do período registrado e os sistemas tropicais (continental e atlântico) controlaram durante o restante do tempo $(35,1 \%)$. Os sistemas atlânticos obtiveram maior atuação, fato justificado pela proximidade da área de estudo com o Oceano Atlântico.

\subsection{Eventos extremos de precipitação: conceitos e estudo de casos}

No campo de pesquisas da Climatologia Geográfica, as abordagens tradicionais (quantitativas) e dinâmicas (qualitativas) devem estar integradas ao espaço regional, onde parâmetros admitidos para uma área podem não ser válidos para outras; o pesquisador deve definir o que é habitual e o que é excepcional (MONTEIRO, 1971).

No meio tropical, as relações entre natureza e sociedade se dão de maneira conflituosa, visto que as ocupações desordenadas acentuam as consequências de desastres naturais. Conti (2001) resgata estudos realizados sobre desastres ocorridos no Vale do Paraíba (entre os estados do Rio de Janeiro e Minas gerais no ano de 1948) e em Caraguatatuba (1967) e realiza um estudo comparativo com eventos desenvolvidos na região da Serra da Mantiqueira e no Vale Médio do Paraíba do Sul no ano de 2000. Para o autor, a gênese dos eventos é a mesma: estacionamento da Frente Polar durante uma sequência de dias e o alinhamento do relevo (SO-NE). A comparação dos episódios comprova a vulnerabilidade do Sudeste do Brasil às precipitações extremas, que aliadas à ocupação humana resultaram em tragédias com perdas materiais e humanas.

A definição frequentemente utilizada de evento extremo é baseada na distribuição climatológica esperada de um evento. Um evento é chamado extremo neste sentido se estiver nos extremos da distribuição climatológica (ZHU; THOT, 2001). Um evento extremo também pode ser

um termo usado em climatologia para os maiores ou menores valores de um parâmetro meteorológico específico para o período em análise (geralmente um mês, estação ou ano). Quando aplicado para 
todo o período para os quais os registros estão disponíveis pode ser descrito como um extremo absoluto ${ }^{11}$ (DUNLOP, 2008, p.83).

Espírito Santo e Satyamurty (2002), para o Sudeste, consideram como evento extremo as precipitações de $100 \mathrm{~mm}$ a $150 \mathrm{~mm}$ que ocorrem em um intervalo de 24 horas, sendo que as regiões litorâneas foram as mais propícias às chuvas extremas dentro do limiar definido no estudo.

No estudo sobre os impactos causados por eventos pluviométricos intensos no município de Curitiba (PR), Zanella (2006) considera que os episódios pluviométricos causadores de grandes impactos são aqueles iguais e acima de 60 mm em 24 horas, ou a soma de chuva em três dias seguidos que atingem ou ultrapassem este valor. A autora mostra que há relação entre ocupações irregulares na periferia da cidade e a ocorrência de inundações e suas consequências, provocadas pelos eventos extremos de chuva.

Para as cidades de Crato, Fortaleza e Sobral, Monteiro e Zanella (2017) definiram, com base na literatura, o limiar de $50 \mathrm{~mm}$ em 24 horas para a ocorrência de eventos extremos. Contudo, não houve ponderação no fato que os limiares, adequados estatisticamente, não consideram as especificidades de cada localidade.

Cavalcanti (2012) realizou uma revisão acerca de eventos extremos na América do Sul e utiliza estudos de caso que ocorreram na primeira década do século XXI. Segundo a autora, as regiões Sul e Sudeste do Brasil são vulneráveis aos eventos extremos de precipitações devido à influência de sistemas meteorológicos como a Zona de Convergência do Atlântico Sul (ZCAS), durante o verão, e os sistemas frontais, no período de outono e inverno.

Na região nordeste da Argentina, pertencente à bacia do Rio da Prata, Lovino et al. (2014) desenvolveram uma análise espaço-temporal das precipitações extremas aplicando análises de tendências que definiram o grau de vulnerabilidade da região. Os resultados mostram que a área de estudo, principalmente o setor centro-oeste, é vulnerável aos eventos extremos de precipitação, tanto para períodos chuvosos quanto para períodos secos, fazendo-se necessária a implantação de uma gestão de recursos hídricos eficiente.

Santos e Galvani (2014), ao realizar um trabalho sobre a distribuição horária e sazonal das precipitações em Caraguatatuba, definem faixas de frequências de

\footnotetext{
${ }^{11}$ Tradução livre da autora.
} 
precipitações, para a determinação dos eventos extremos ocorridos na área de estudo no período de 2007 a 2011. Os autores consideram "extremos" os eventos diários acima de $40 \mathrm{~mm}$. As análises registraram nove eventos, sendo que destes, seis ocorreram durante o fim da tarde e início da noite, no período mais chuvoso (verão e primavera), onde há a influência da convecção térmica (aquecimento do oceano) e do relevo. Durante o outono e o inverno, as chuvas são condicionadas à passagem de sistemas frontais e podem ocorrer em qualquer horário do dia.

Para determinar os anos com regime pluviométrico seco, normal ou úmido em Piracicaba (SP), Galvani e Luchiari (2012) adotaram os gráficos de Box Plot. Os autores adotaram um range de 5 a 95\% da série histórica, ou seja, os valores de precipitação mensal abaixo de 5\% e acima de 95\% são considerados extremos (super-secos e super-úmidos, respectivamente); Os valores entre o mínimo e o $1^{\circ}$ quartil (25\%) são os meses secos; entre o $1^{\circ}$ e o $3^{\circ}$ quartil são os meses normais e entre o $3^{\circ}$ quartil e o valor máximo, são os meses úmidos. De acordo com o estudo, esta avaliação selecionada por meses contribui para o conhecimento do regime sazonal das precipitações, principalmente no âmbito da climatologia agrícola.

Ao realizar a correspondência entre eventos extremos de precipitação e notícias históricas de jornais em Belém (PA), Campos, Mota e Santos (2015) aplicaram a técnica dos quantis, baseado em Xavier et at. (2007). Os autores definiram decis $(10 \%, 20 \% . . .90 \%)$ para os dados de precipitação diária, de modo que o nono decil corresponde à ocorrência dos eventos extremos. Para a referida área de estudo, foi definido que um evento extremo ocorre quando a precipitação diária é superior a $24 \mathrm{~mm}$.

Inserido no debate sobre a definição do que são os eventos extremos, existe também o interesse em avaliar seus impactos sobre a sociedade, principalmente no meio urbano. Para Armond e Sant'anna Neto (2017), é necessário reconhecer a diferenciação entre o que é um evento extremo de chuva, caracterizado pela sua origem estatística (que está fora do padrão climatológico para determinada área) e o que é um episódio extremo, designado como de natureza geográfica, pois envolve a produção desigual do espaço que sofre com os impactos causados pelos eventos (alagamentos, inundações deslizamentos, entre outros). Este estudo se preocupará apenas com a ocorrência de eventos extremos, dada a natureza das séries históricas aqui trabalhadas. 
Oliveira e Galvani (2017), no perfil Paraty (RJ) - Campos do Jordão (SP), utilizam a técnica estatística dos gráficos Box Plot, que classifica a série de dados pluviométricos em quantis, onde os outliers representam os valores extremos. Segundo os autores, as séries históricas apresentaram muitos dias com chuvas menos intensas, porém os eventos extremos existentes devem ser considerados devido sua intensidade. No estudo, as análises via Box Plot foram importantes, pois esta técnica gera resultados detalhados, permitindo um melhor conhecimento da variabilidade pluviométrica da área de estudo.

Caballero et al. (2018) selecionaram os eventos extremos ocorridos no municípios de Pelotas (RS) com o uso do critério do tempo médio de deslocamento dos sistemas atmosféricos. Os autores definiram como extremo os eventos de 120,0 $\mathrm{mm}$ ou acima em um período de dois dias consecutivos, visto que na maior parte dos casos um sistema meteorológico tem início em um determinado dia e se dissipa no dia seguinte.

Para a cidade de Recife, Wanderley et al. (2018) aplicaram a técnica dos quantis para classificar os eventos extremos diários (quantis 0,85 e 0,95 considerados forte e extremamente forte $=25,1 \mathrm{~mm}$ e $50,8 \mathrm{~mm}$, respectivamente). Para os autores, a maior recorrência de eventos extremos entre os meses de março a agosto pode ser explicada pela atuação frequente de sistemas sinóticos convectivos, entre os quais se destacam os Distúrbios Ondulatórios de Leste e a Zona de Convergência Intertropical (ZCIT). 


\section{PROCEDIMENTOS METODOLÓGICOS}

\subsection{Seleção e organização do banco de dados}

Para esta pesquisa foram selecionados dados secundários de nove postos pluviométricos na área de estudo: quatro localizados no município de Caraguatatuba e cinco localizados no município de Ubatuba, fornecidos pelo $D_{A E E^{12}}$, por meio de sua plataforma online de dados pluviométricos e hidrológicos do estado de São Paulo.

As séries históricas compreendem períodos distintos, fato que não permite uma comparação linear entre todos os postos; deste modo, as análises de estatística descritiva serão realizadas individualmente e para seleção de eventos extremos foram selecionados os postos de acordo com sua localização geográfica (altitude em relação ao nível do mar e representação espacial no contexto da área de estudo). A tabela 5 e a figura 11 apresentam a localização de cada posto pluviométrico; na tabela encontram-se as porcentagens de falhas, respectivamente.

Tabela 5: Localização dos postos pluviométricos e porcentagem de falhas do banco de dados.

\begin{tabular}{|c|c|c|c|c|c|c|}
\hline Prefixo & Período & Nome do Posto & $\begin{array}{c}\text { Altitude } \\
\text { (m) }\end{array}$ & Latitude & Longitude & $\begin{array}{c}\text { Falhas }^{13} \\
(\%)\end{array}$ \\
\hline E2-042 & $1943-1970$ & $\begin{array}{l}\text { CARAGUATATUBA } \\
\text { (DER) }\end{array}$ & 20,0 & $23^{\circ} 35^{\prime} 00^{\prime \prime}$ & $45^{\circ} 27^{\prime} 00^{\prime \prime}$ & 6,6 \\
\hline E2-043 & $1943-1971$ & $\begin{array}{c}\text { BAIRRO DO RIO } \\
\text { D'OURO }\end{array}$ & 200,0 & $23^{\circ} 37^{\prime} 00^{\prime \prime}$ & $45^{\circ} 26^{\prime} 00^{\prime \prime}$ & 0,7 \\
\hline E2-046 & $1943-2014$ & CARAGUATATUBA & 20,0 & $23^{\circ} 38^{\prime} 00^{\prime \prime}$ & $45^{\circ} 26^{\prime} 00^{\prime \prime}$ & 1,7 \\
\hline E2-128 & 1970-1997 & PORTO NOVO & 10,0 & $23^{\circ} 42^{\prime} 00^{\prime \prime}$ & $45^{\circ} 27^{\prime} 00^{\prime \prime}$ & 11,6 \\
\hline E1-003 & 1944-1974 & $\begin{array}{l}\text { PONTA DA } \\
\text { TRINDADE }\end{array}$ & 2,0 & $23^{\circ} 22^{\prime} 00^{\prime \prime}$ & $44^{\circ} 44^{\prime} 00^{\prime \prime}$ & 4,3 \\
\hline E1-004 & $1944-2000$ & PICINGUABA & 3,0 & $23^{\circ} 23^{\prime} 00^{\prime \prime}$ & $44^{\circ} 50^{\prime} 00^{\prime \prime}$ & 12,2 \\
\hline E2-009 & $1956-2016$ & MATO DENTRO & 220,0 & $23^{\circ} 23^{\prime} 00^{\prime \prime}$ & $45^{\circ} 07^{\prime} 00^{\prime \prime}$ & 7,3 \\
\hline E2-052 & $1945-2016$ & UBATUBA & 1,0 & $23^{\circ} 26^{\prime} 00^{\prime \prime}$ & $45^{\circ} 04^{\prime} 00^{\prime \prime}$ & 12,9 \\
\hline E2-122 & $1970-2001$ & MARANDUBA & 4,0 & $23^{\circ} 32^{\prime} 00^{\prime \prime}$ & $45^{\circ} 14^{\prime} 00^{\prime \prime}$ & 7,1 \\
\hline
\end{tabular}

Fonte: DAEE. Org: Santos, 2019.

\footnotetext{
12 O Departamento de Águas e Energia Elétrica- DAEE é o órgão gestor dos recursos hídricos do Estado de São Paulo. Fonte: http://www.daee.sp.gov.br.

${ }^{13}$ A Organização Meteorológica Mundial recomenda a não utilização de séries mensais com dados ausentes em 3 dias consecutivos ou 5 dias alternados (WMO, 1989).
} 
Figura 11: Localização dos postos pluviométricos ${ }^{14}$ na área de estudo.

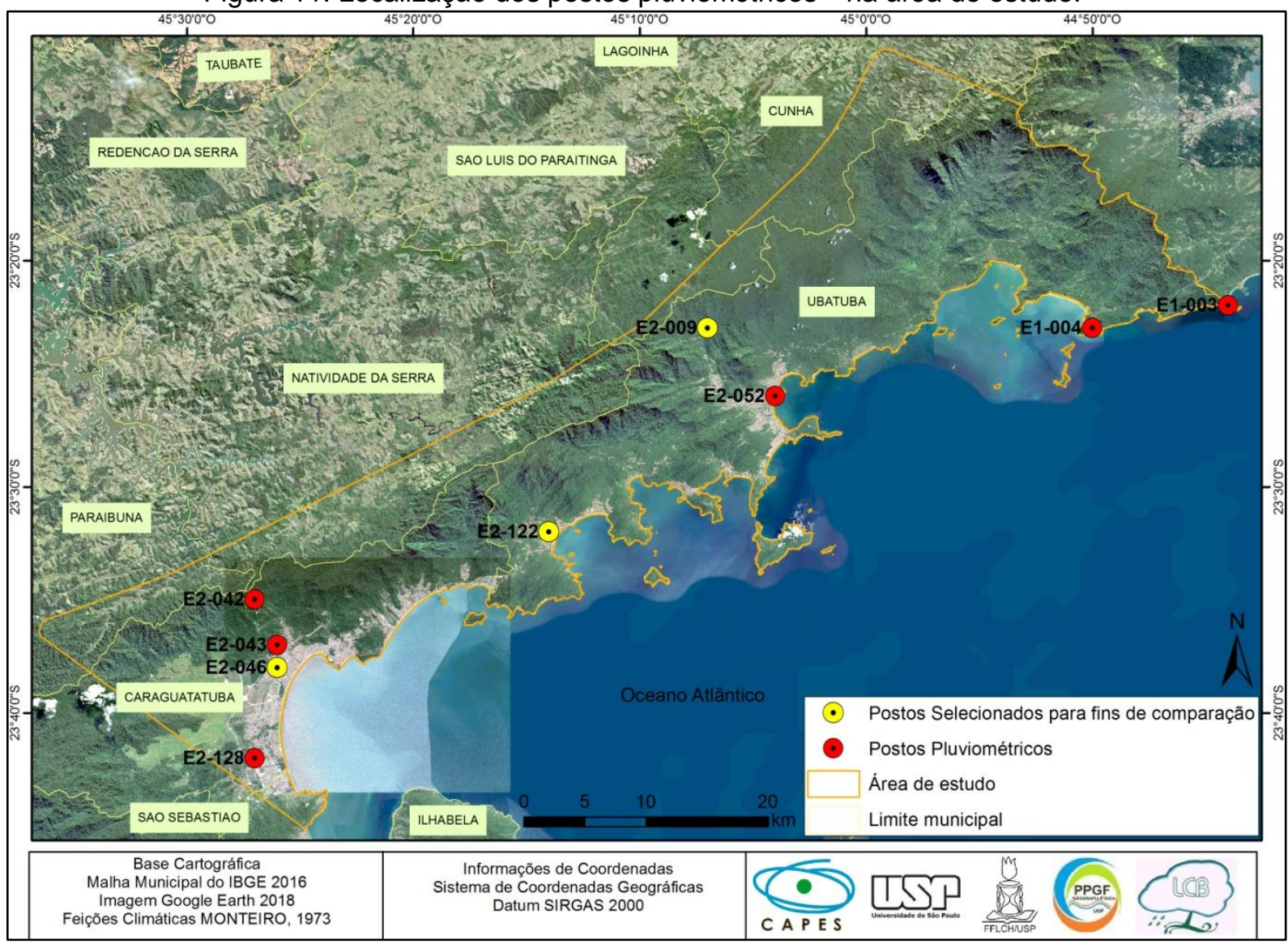

Org.: Santos e Baratto, 2018.

\subsection{Análises estatísticas e definição de eventos extremos}

$\mathrm{Na}$ análise de estatística descritiva, os cálculos envolveram as médias mensais, anuais e sazonais ${ }^{15}$ para os nove postos pluviométricos e também os desvios absolutos de precipitação em relação à média de cada série histórica, considerando os anos com maior e menor volume de precipitação, para cada posto pluviométrico. Todos os resultados foram sintetizados através de gráficos produzidos no software Microsoft Excel.

O software Statistica foi utilizado como recurso técnico na elaboração dos gráficos de frequência diária e Box Plox. Os dados foram organizados em ordem crescente e os intervalos de frequência foram estabelecidos de acordo com Santos e Galvani (2014), que aplicaram esta técnica para os dados diários em Caraguatatuba, com a adoção das classes de chuva de $1,0 \mathrm{~mm}$ a $10,0 \mathrm{~mm}$, de $10,0 \mathrm{~mm}$ a $30,0 \mathrm{~mm}$,

\footnotetext{
${ }_{15}^{14} \mathrm{Em}$ amarelo estão os postos pluviométricos selecionados para as análises comparativas.

15 Para a definição das estações do ano, foram estabelecidas como parâmetro as datas dos equinócios (outono e primavera) e dos solstícios (verão e inverno) no Hemisfério Sul.
} 
de $30,0 \mathrm{~mm}$ a $50,0 \mathrm{~mm}$, de $50,0 \mathrm{~mm}$ a $80,0 \mathrm{~mm}$ e acima de $80, \mathrm{~mm}$. Os autores consideraram que os eventos extremos de chuva são aqueles que atingem e ultrapassam os $80,0 \mathrm{~mm}$ em 24 horas.

Para definir o limiar de ocorrência dos eventos extremos de precipitação, utilizou-se a técnica do Box Plot, que é amplamente empregada para a definição de alguns parâmetros de estatística descritiva como valor máximo e valor mínimo, mediana, quartis e outliers (GALVANI; LUCHIARI, 2012); a figura 12 apresenta um esquema de representação gráfica do Box Plot.

Figura 12: Exemplo de representação de Box Plot.

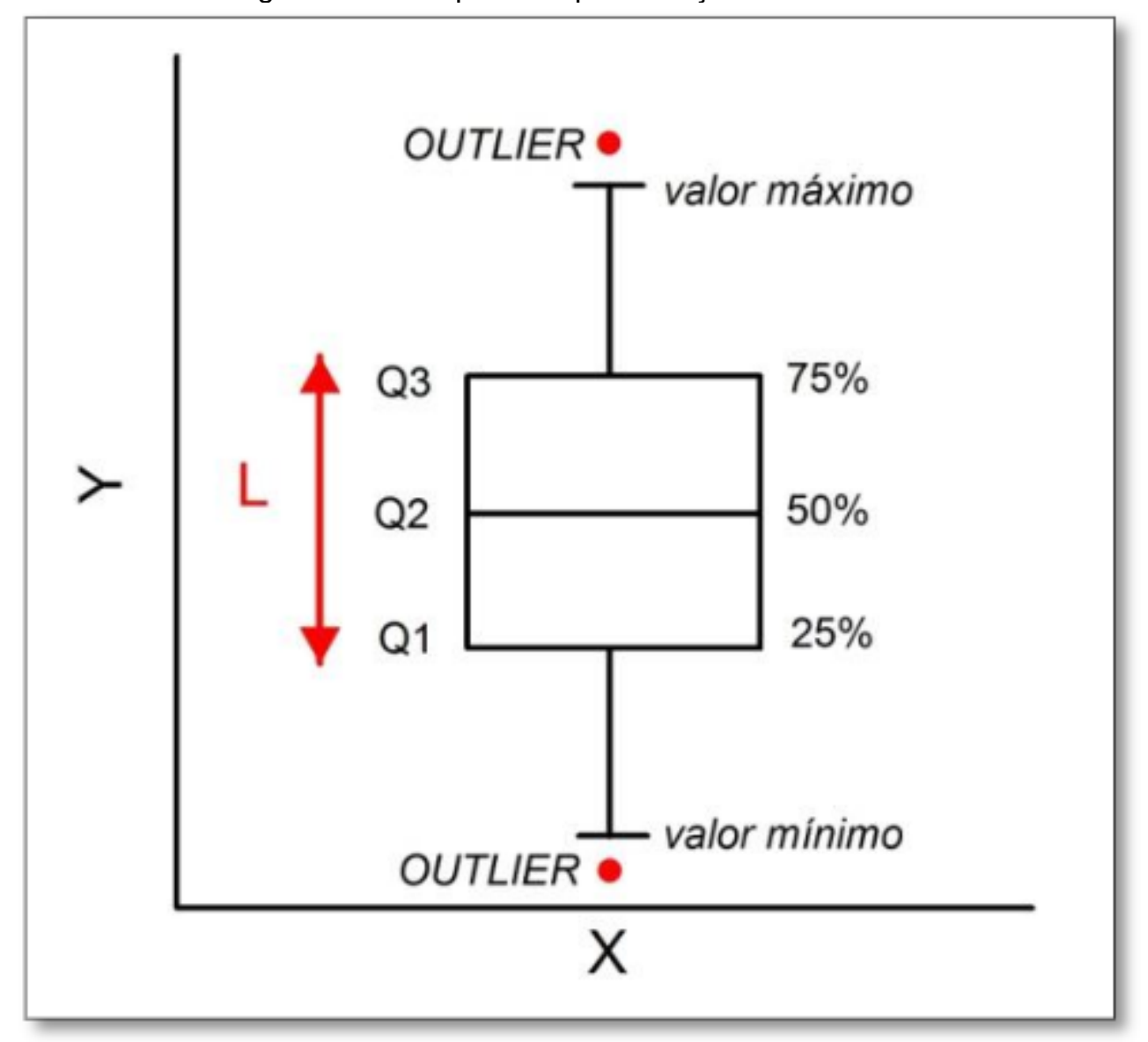

Fonte: Oliveira e Galvani, 2017.

Neste estudo, para o box os procedimentos envolveram a definição de percentis, a saber: base inferior na ordem de $5 \%$ dos dados; base superior na ordem de $95 \%$ dos dados. Os whiskers (prolongamentos do box) se estendem até o limiar definido para os eventos extremos inferiores ${ }^{16}$ e superiores.

\footnotetext{
${ }^{16}$ Neste trabalho os valores extremos inferiores são serão tratados.
} 
Para a elaboração dos gráficos de Box Plot dados diários foram estruturados em ordem crescente; considerou-se apenas os dias com chuva, cuja precipitação foi igual ou superior a $1 \mathrm{~mm}$ em 24 horas, de acordo com a recomendação da Organização Meteorológica Mundial (OMM), aplicada por Ramos et al. (2009) e Espírito Santo e Satyamurty (2002). Estabeleceu-se os quantis (percentis) ${ }^{17}$ de ordem $1 \%$ a $99 \%$, ou seja, valores inclusos neste intervalos são considerados habituais. As precipitações cujos valores extrapolam os $99 \%$ do conjunto de dados foram consideradas eventos extremos. Ao definir o limiar da ocorrência dos extremos (precipitações acima dos $99 \%$ ), os eventos encontrados organizados em tabelas de acordo com sua data de ocorrência (dia, mês, ano e sazonalidade).

Dentre os postos pluviométricos, foram selecionados três de referência (cotas nas altitudes de 4, 20 e 220 metros acima do nível médio do mar) para fins de comparação. Com a aplicação da técnica de Box Plot, foi possível a delimitação do limiar de ocorrência de eventos extremos para cada posto, como também comparar a distribuição temporal dos mesmos.

Nas sequências de três ou mais eventos a cada ano, realizou-se a comparação com os dados de ocorrência da anomalia ENOS (El Niño Oscilação Sul) com a função de verificar se os eventos extremos de precipitação são influenciados por ele. Este fenômeno

representa o aquecimento anormal das águas superficiais e subsuperficiais do Oceano Pacífico Equatorial. (...) Com esse aquecimento do oceano e com o enfraquecimento dos ventos, começam a ser observadas mudanças da circulação da atmosfera nos níveis baixos e altos, determinando mudanças nos padrões de transporte de umidade, e portanto variações na distribuição das chuvas em regiões tropicais e de latitudes médias e altas (OLIVEIRA, 2001; CPTEC/INPE, 2019).

Para avaliar a ocorrência de eventos extremos em relação ao tempo (em anos), utilizou-se o coeficiente de correlação ( $r$ ) definido por Crespo (2002): fraco $(0,0$ a 0,3$)$, moderado $(0,3$ a 0,6$)$ e forte (maior que 0,7$)$. A correlação é nula quando tem o valor de zero; quanto mais próxima dos valores de 1 (correlação positiva) ou 1 (correlação negativa), mais exata é a correlação as variáveis (tempo e eventos extremos, para este caso).

17 "Quantis (...) são medidas de separação para distribuições de probabilidade ou para suas amostras. Um quantil de ordem $\mathbf{p}$ (definido para $0<\mathbf{p}<1$ ) é um valor numérico que secciona a distribuição em duas partes, com probabilidades $\mathbf{p}$ (à esquerda deste quantil 'teórico') e 1-p (à direita) [grifo dos autores]." (XAVIER; XAVIER; ALVES, 2007, p.3). 


\section{RESULTADOS E DISCUSSÃO}

\subsection{Estatística descritiva dos postos pluviométricos}

\subsubsection{Análise anual}

As análises de estatística descritiva foram realizadas de forma individualizada (posto a posto), visto que as séries históricas se diferem em relação ao número de registros e períodos registrados.

O posto E2-042, localizado em Caraguatatuba a 20 metros acima do nível médio do mar, apresenta uma série histórica de 27 anos (com $6,6 \%$ de falhas). A precipitação média anual registrada foi de 2203,8 mm/ano; na série, 13 anos registraram valores acima da média. O ano de 1947 apresentou o maior desvio absoluto, principalmente nos meses de novembro, dezembro e janeiro. Ainda em relação à média, o menor desvio absoluto ocorreu no ano de 1970, com destaque para os meses de janeiro, dezembro de novembro (figuras 13 e 14).

Figura 13: Distribuição anual da precipitação no posto E2-042.

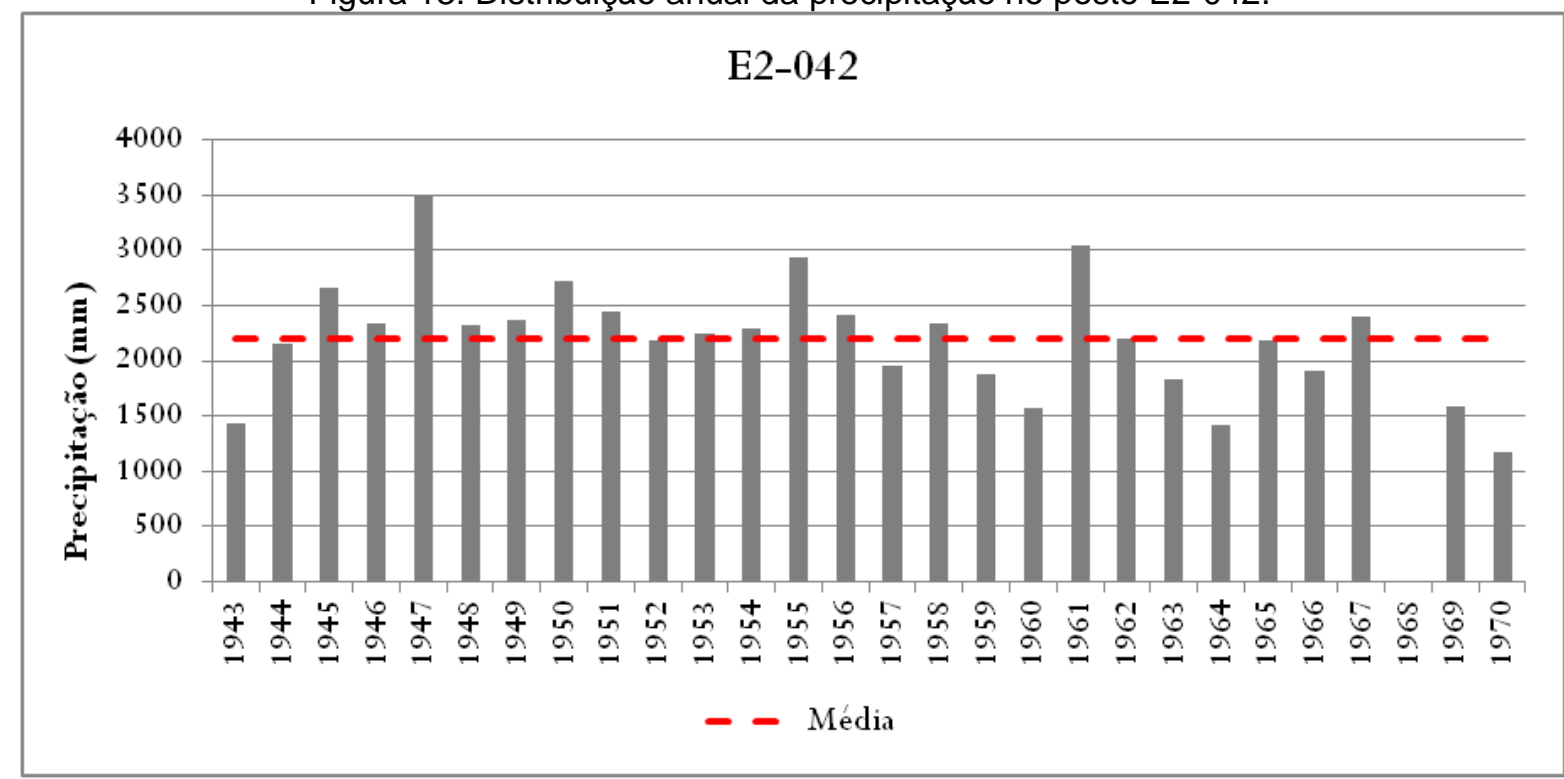

Org.: Santos, 2019. 
Figura 14: Desvios absolutos em relação à média do posto E2-042.

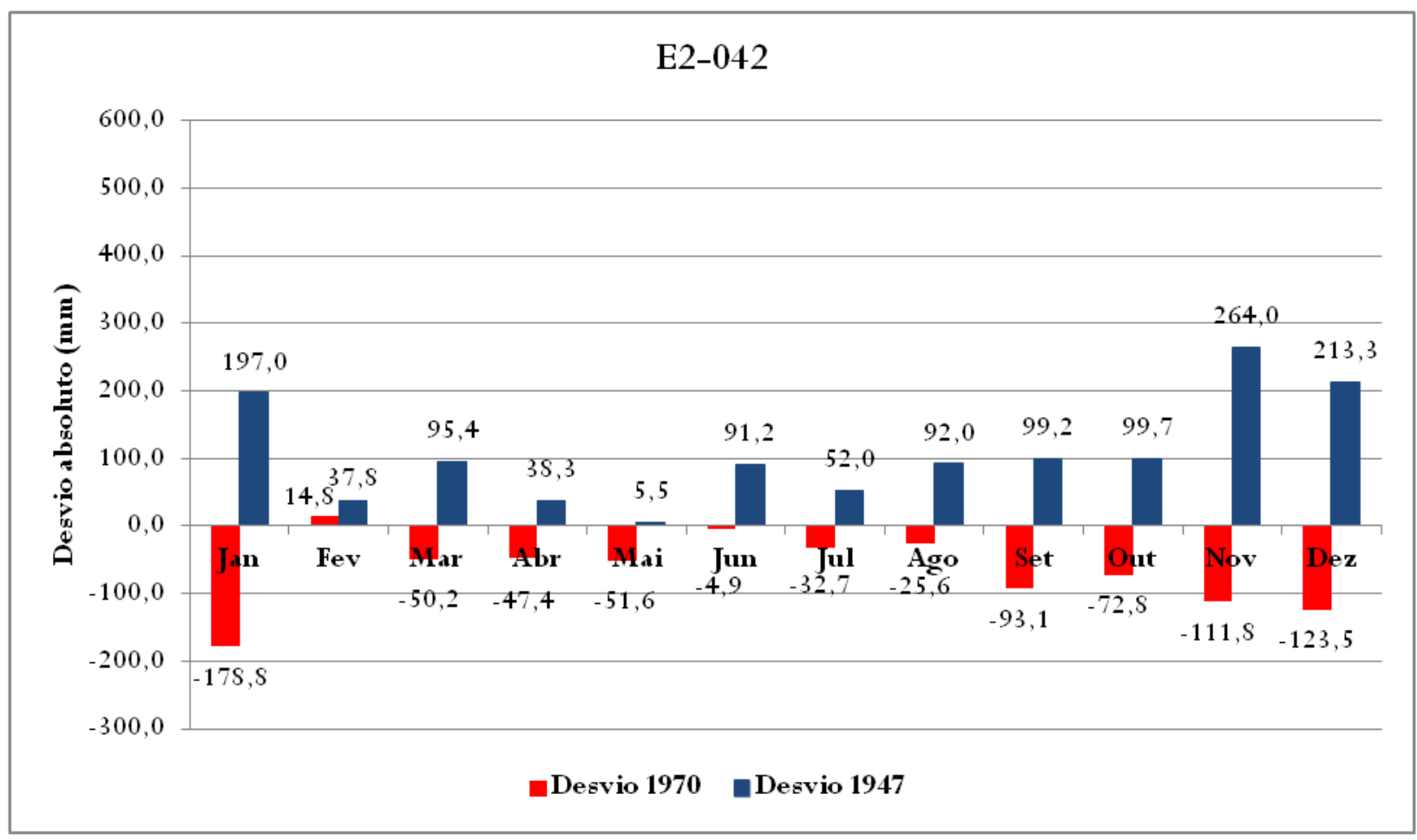

Org.: Santos, 2019.

O posto E2-043 está localizado a 200 metros acima do nível do mar, no bairro do Rio do Ouro, em Caraguatatuba. Sua série histórica possui $0,7 \%$ de falhas no banco de dados em um período de 28 anos de registros. O valor médio de precipitação anual foi de $2162,7 \mathrm{~mm} / \mathrm{ano}$. Em relação a este valor, também no ano de 1947 ocorreu o maior desvio médio, representados principalmente pelos meses de dezembro e janeiro. O ano de 1968 apresentou os menores desvios, evidentes nos meses de fevereiro, dezembro e março (figuras 15 e 16). 
Figura 15: Distribuição anual da precipitação no posto E2-043.

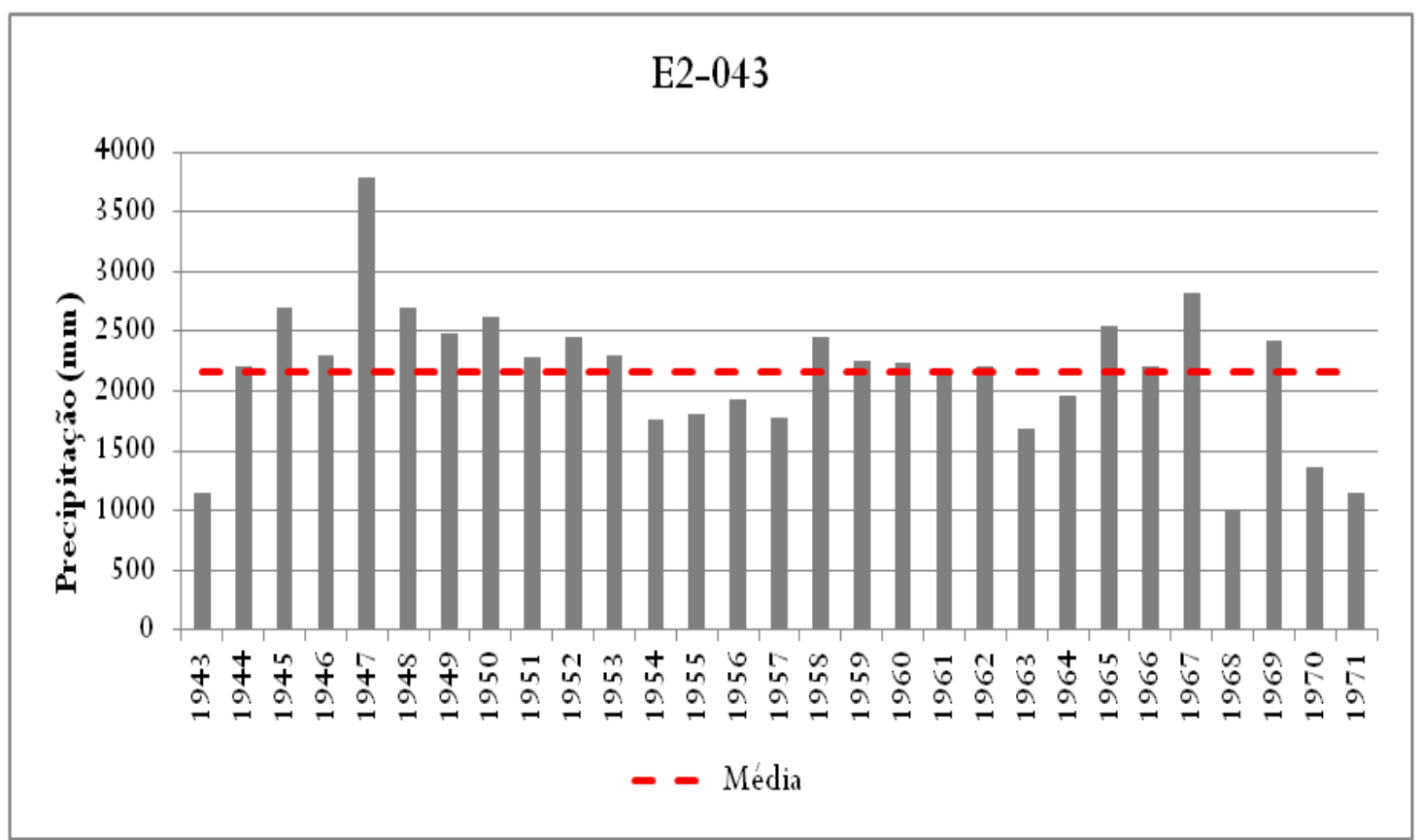

Org.: Santos, 2019.

Figura 16: Desvios absolutos em relação à média do posto E2-043.

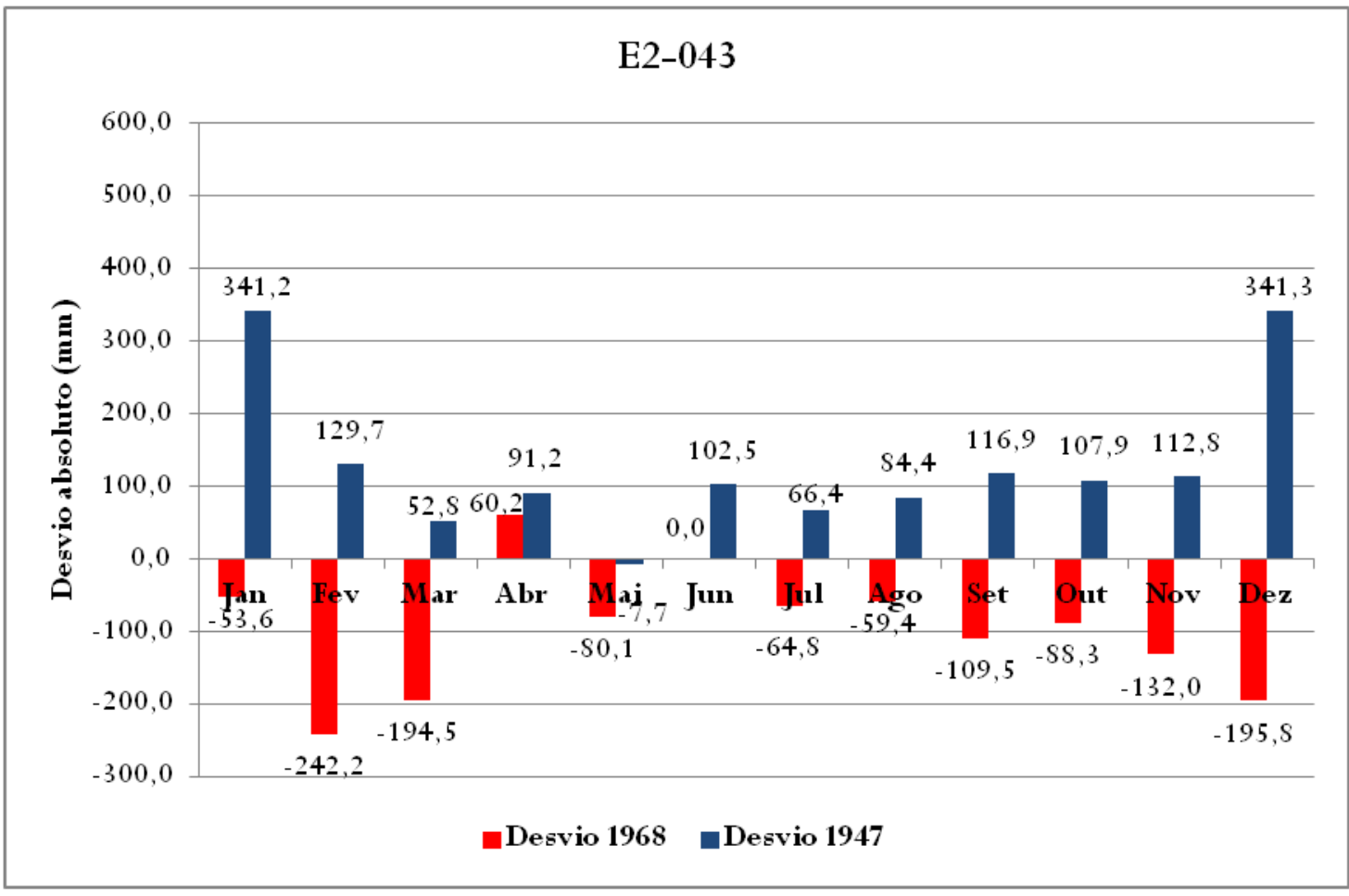

Org.: Santos, 2019. 
O posto E2-046 (localizado a 20 metros de altitude) possui 71 anos de registros com 1,7\% de falhas. Está localizado a 20 metros acima do nível do mar em Caraguatatuba e foi um dos postos de referência para as análises de Box Plot, dada a quantidade de registros e o baixo percentual de falhas. Apresentou média de precipitação de 1733,3 mm/ano (figuras 17 e 18) e seus desvios absolutos ocorreram nos anos de 1947 (positivo) e 1985 (negativo).

Figura 17: Distribuição anual da precipitação no posto E2-046.

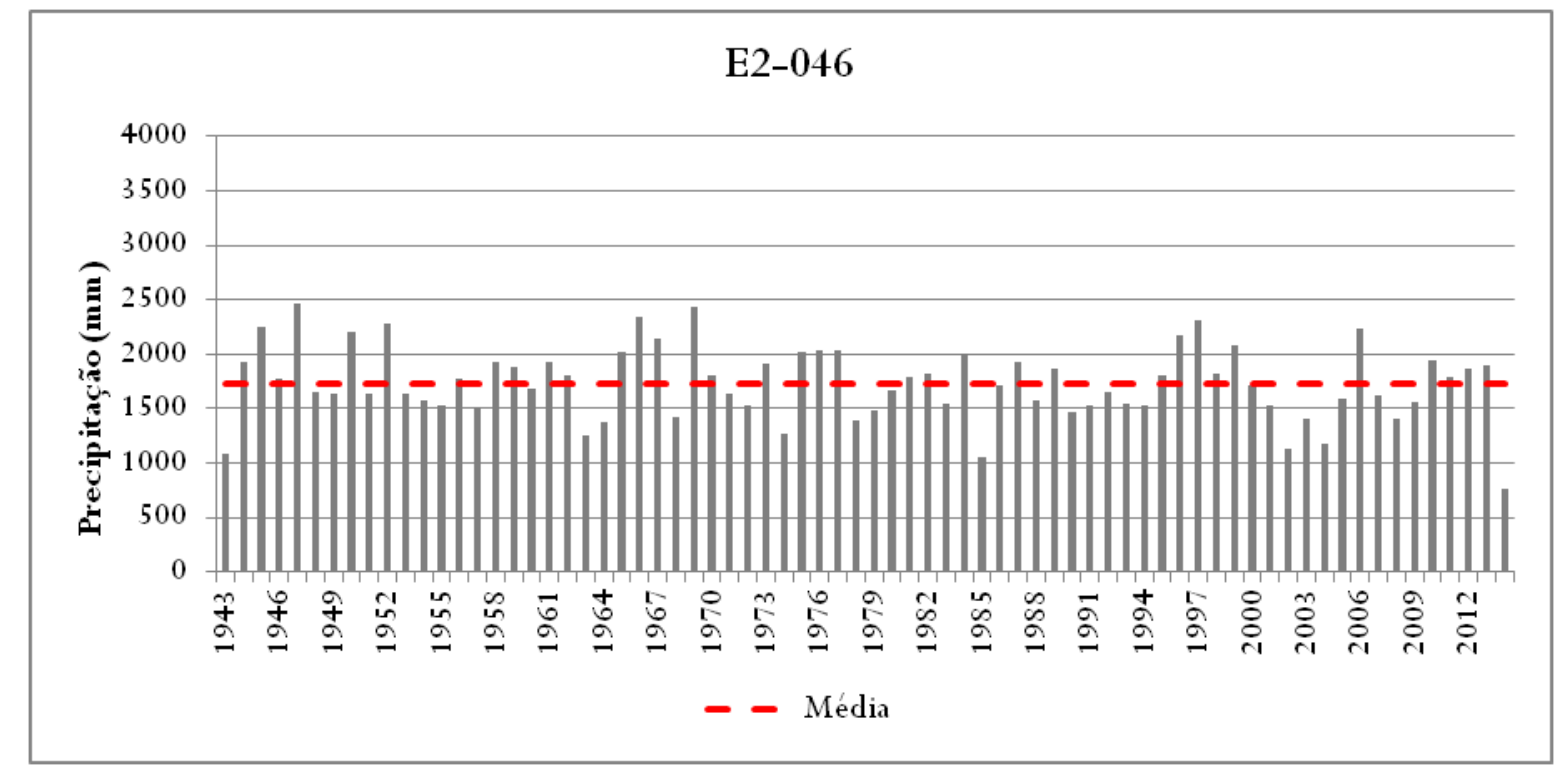

Org.: Santos, 2019.

Figura 18: Desvios absolutos em relação à média do posto E2-046.

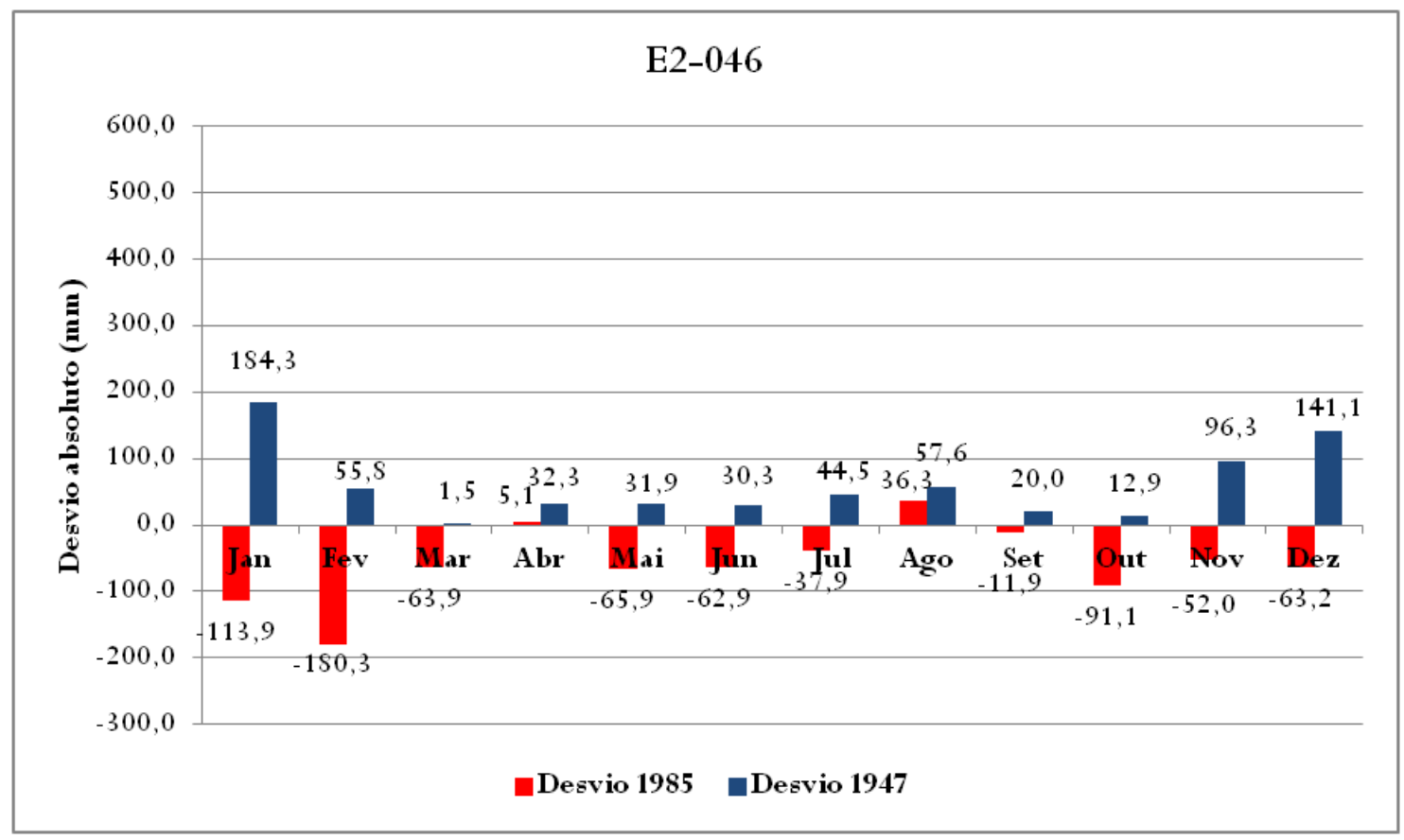

Org.: Santos, 2019. 
O posto E2-128, que se localiza a 10 metros acima do nível do mar, registrou valores de precipitação entre os anos de 1970 e 1997, com 11,7\% de falhas, que o classifica como um posto não confiável para efeitos de comparações. A média de precipitação registrada foi de 1553,8 mm/ano. O ano de 1988 foi classificado como o de maior desvio absoluto em relação à média; atenção especial o mês de abril que registrou 241,8 mm, valor acima do esperado para a região e à estação do ano (outono). O ano de menor desvio foi o de 1992, com $187 \mathrm{~mm}$ a menos do que o normal para o mês de janeiro deste ano (figuras 19 e 20).

Figura 19: Distribuição anual da precipitação no posto E2-128.

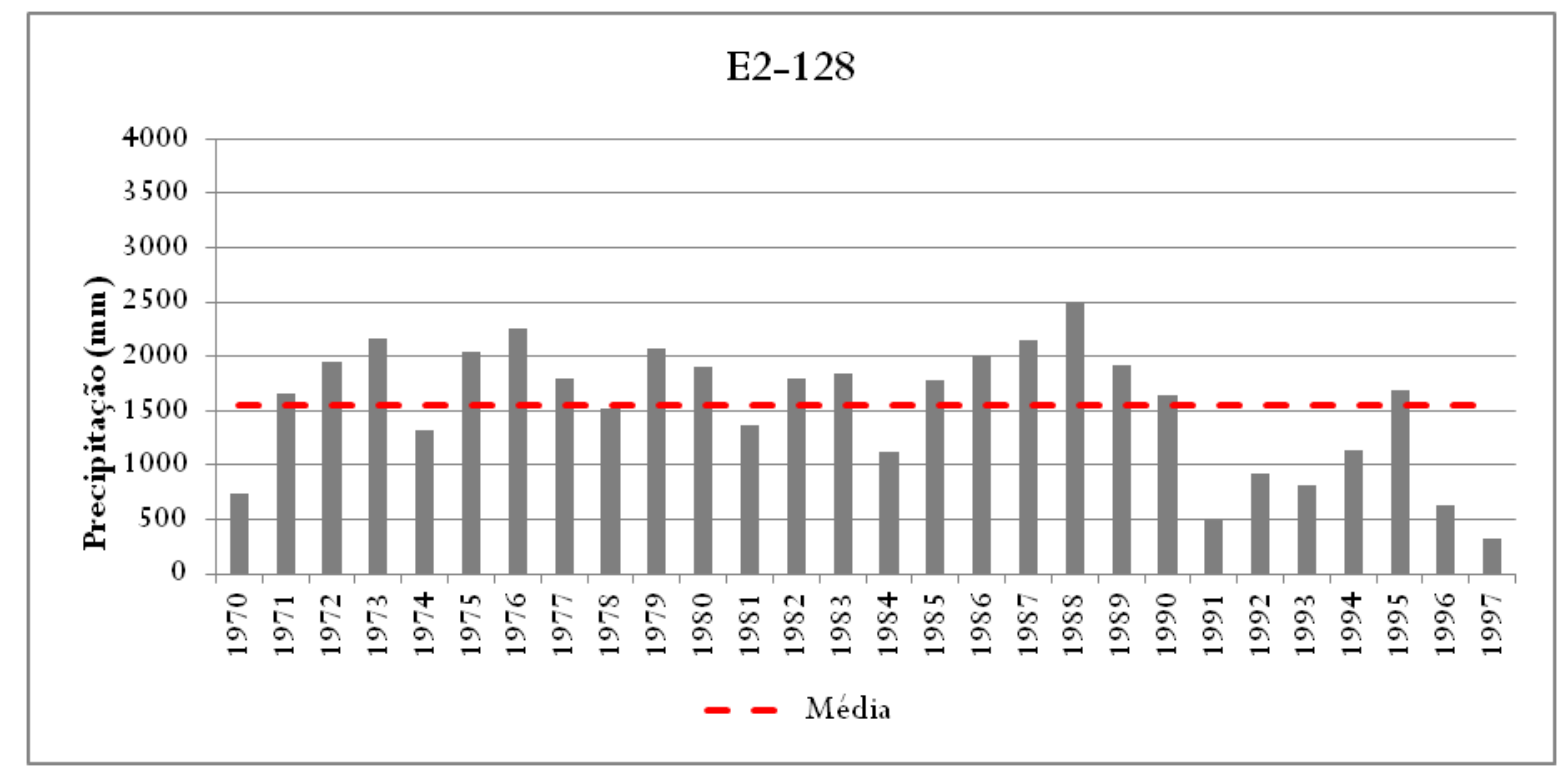

Org.: Santos, 2019. 
Figura 20: Desvios absolutos em relação à média do posto E2-128.

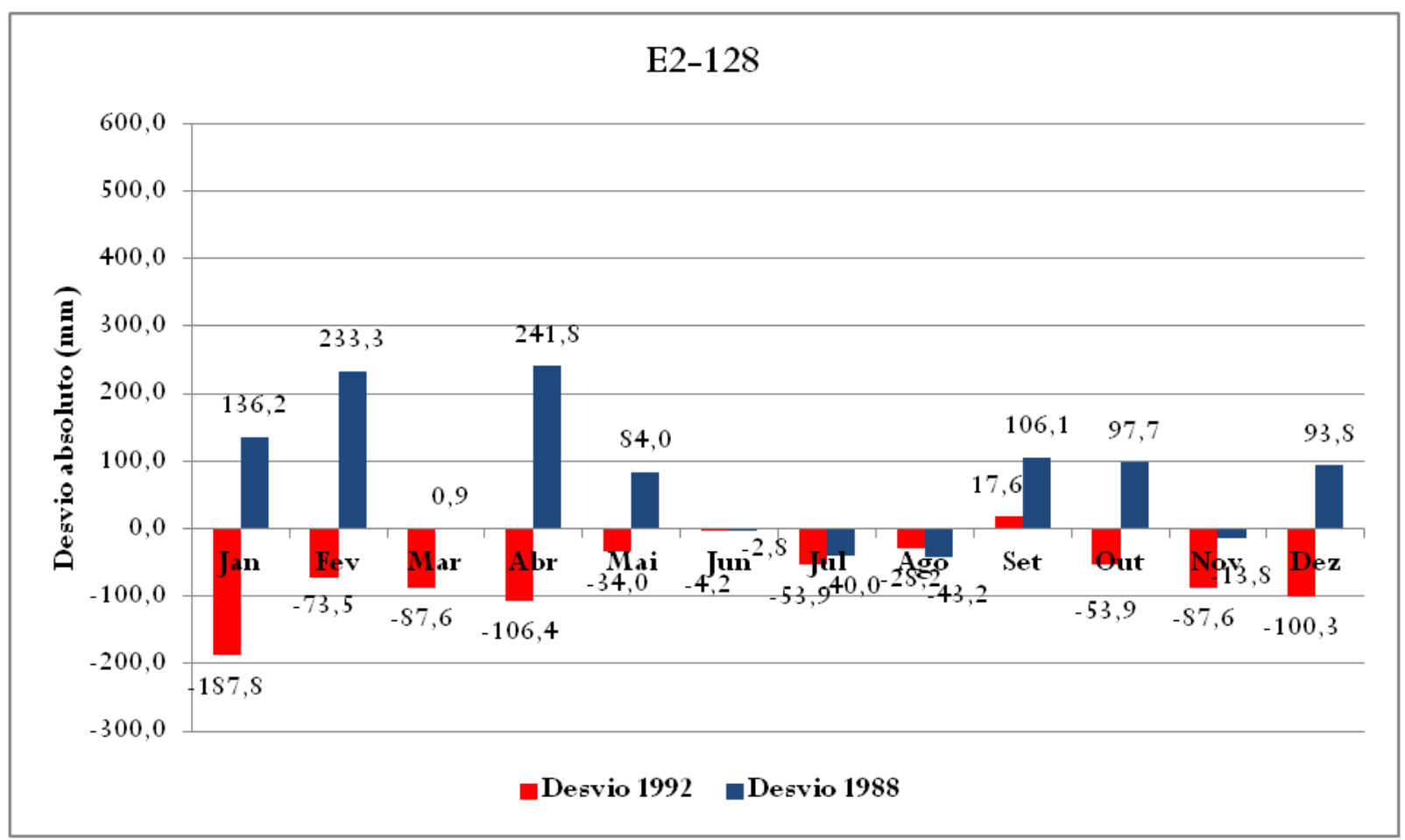

Org.: Santos, 2019.

O posto E1-003 localiza-se no município de Ubatuba a 2 metros acima do nível médio do mar, no limite deste município com a cidade de Paraty, já do estado do Rio de Janeiro. Sua série de 30 anos apresenta 4,3\% de falhas. A precipitação média anual foi de 2390,2 mm/ano e, assim como registrado em três dos quatro postos de Caraguatatuba, o maior desvio absoluto ocorreu no ano de 1947. Porém, nesta localidade os maiores valores mensais foram observados também em meses que, tradicionalmente, há diminuição das chuvas: junho, julho e agosto, durante o inverno. O menor desvio em relação à média ocorreu no ano de 1963, representado principalmente pelo mês de abril com $247 \mathrm{~mm}$ abaixo da média (figuras 21 e 22). 
Figura 21: Distribuição anual da precipitação no posto E1-003.

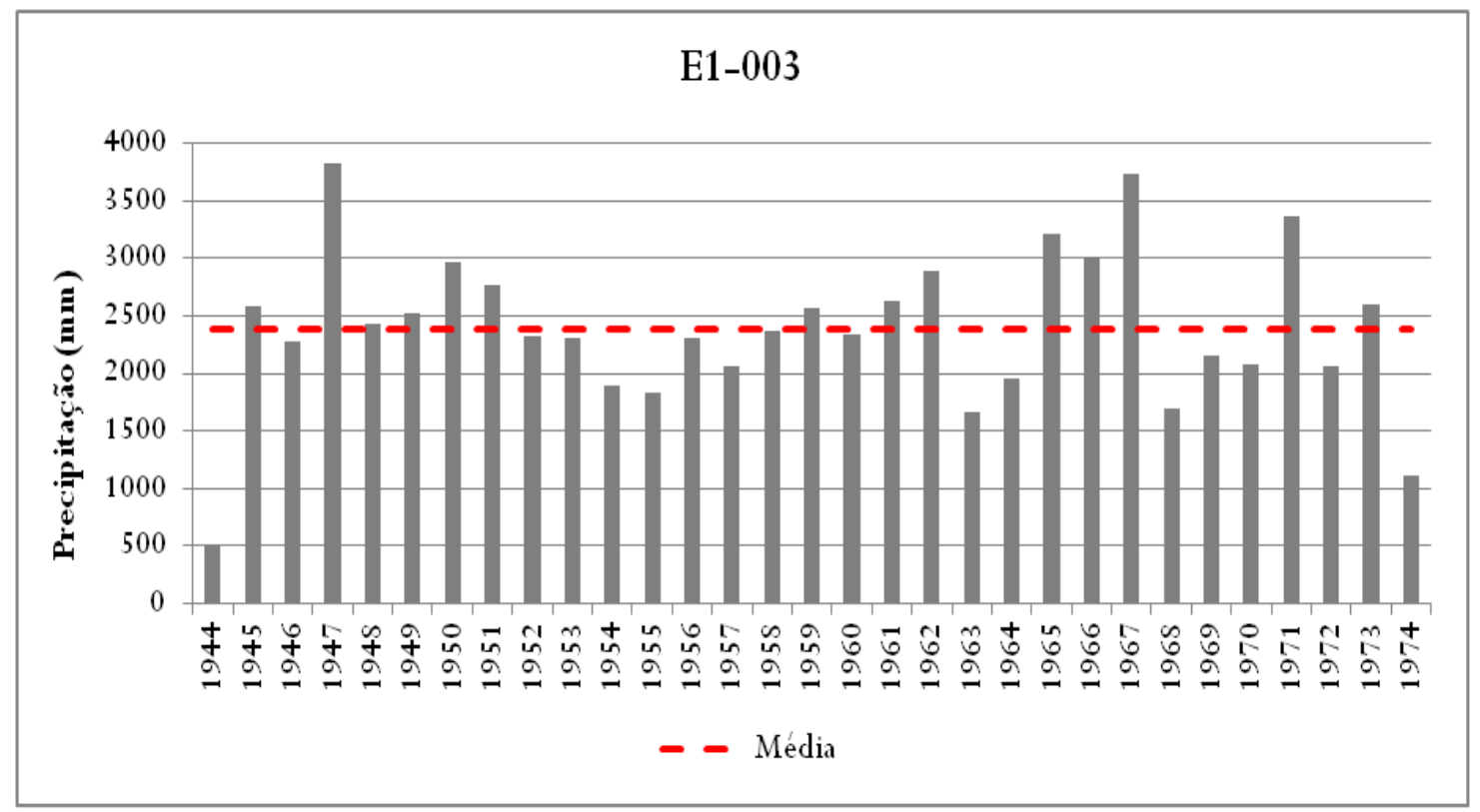

Org.: Santos, 2019.

Figura 22: Desvios absolutos em relação à média do posto E1-003.

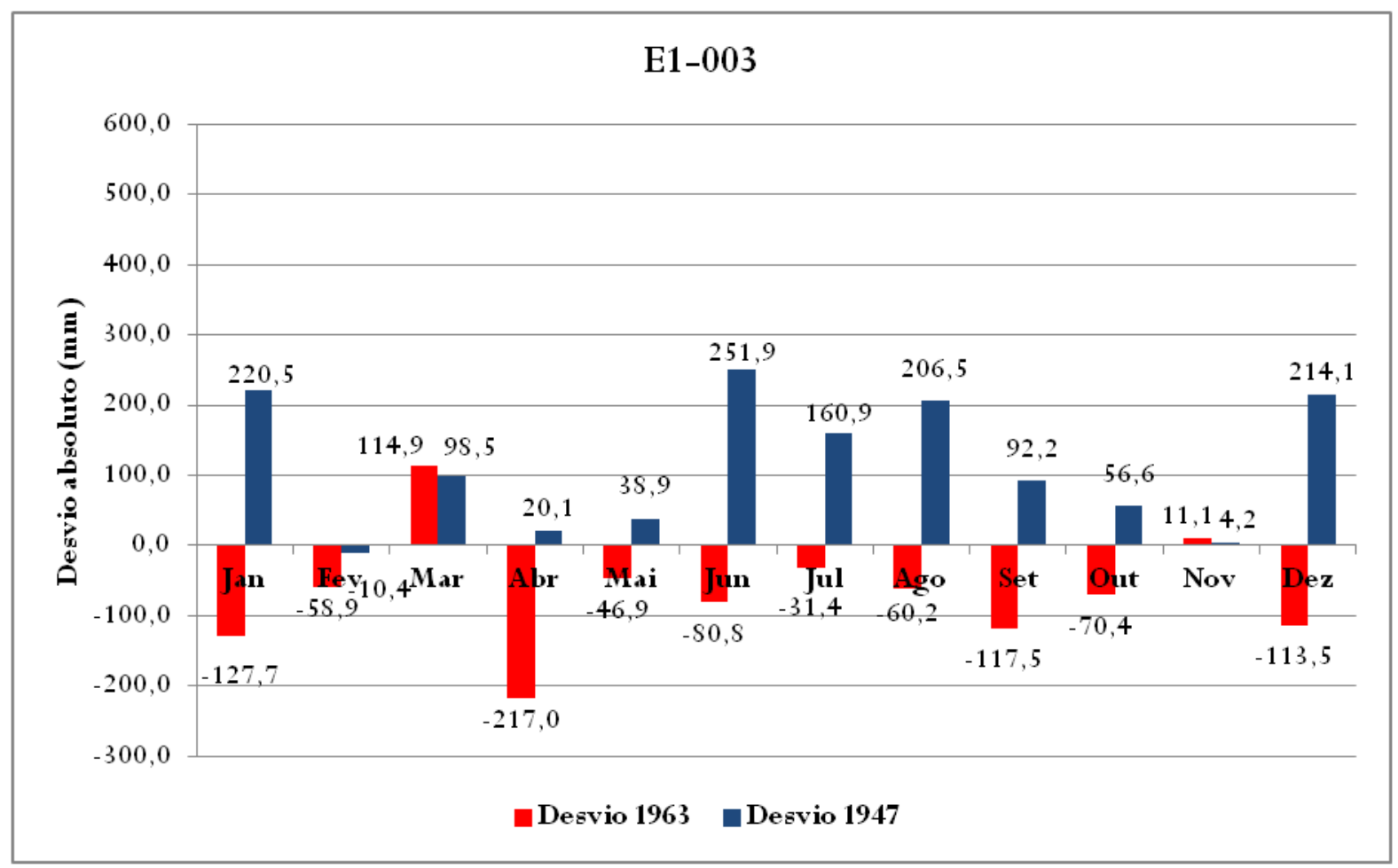

Org.: Santos, 2019.

Localizado em Picinguaba (a 3 metros acima do nível do mar), também no município de Ubatuba, o posto E1-004 apresentou 12,2\% de falhas em seus registros no período de 56 anos de série histórica; também foi classificado como não apto às análises de eventos extremos. Sua média anual de precipitação foi de 
2231,1 mm/ano e, assim como o posto anterior, em 1947 ocorreram os maiores desvios absolutos em relação à média também nos meses de inverno, além da ocorrência esperada em março, dezembro e janeiro; e em 1963 ocorreram os menores desvios, também com o mês de abril em destaque. $\mathrm{O}$ mês de março, em ambos os postos, é a exceção com a ocorrência de desvios positivos em relação à média (figuras 23 e 22).

Figura 23: Distribuição anual da precipitação no posto E1-004.

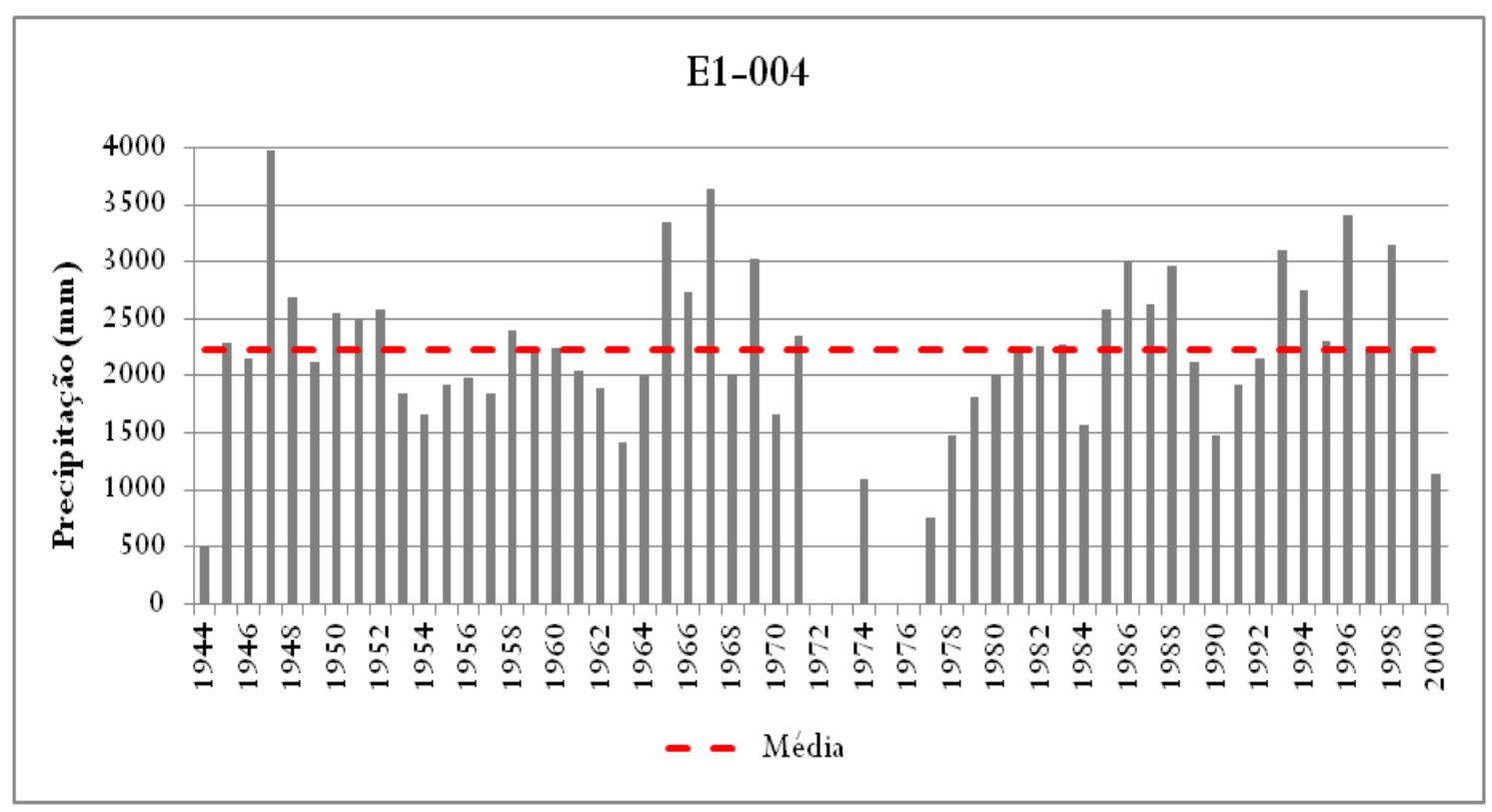

Org.: Santos, 2019. 
Figura 24: Desvios absolutos em relação à média do posto E1-004.

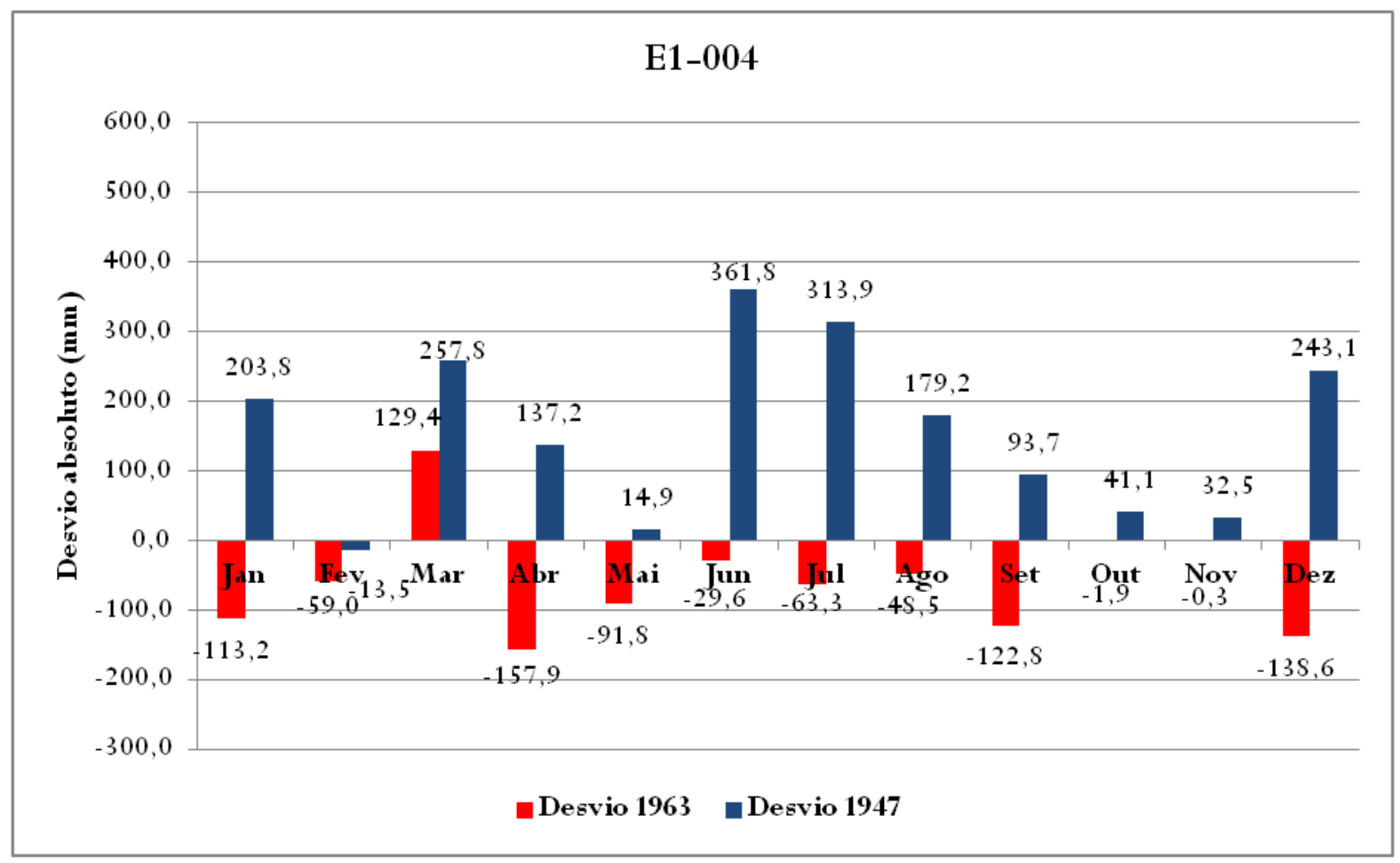

Org.: Santos, 2019.

Para as análises de eventos extremos, o posto E2-009 será considerado, justificado pela sua porcentagem de falhas $(7,3 \%)$ e tamanho da série histórica (60 anos de registros). Dentre os nove postos, é o que apresenta maior média de precipitação anual com 2866,9 mm/ano. O maior desvio absoluto em relação à média foi encontrado no ano de 1967, com 550,9 mm acima da média para o mês de março. Foi neste mês e ano que ocorreu o desastre em Caraguatatuba, quando chuvas intensas provocaram escorregamentos e inundações, com consequências catastróficas (CRUZ, 1974). Também neste posto o menor desvio ocorreu em 1963 com uma exceção no mês de março, registrando um desvio positivo de 135,6 mm (figuras 25 e 26). Os altos valores de precipitação anual e desvios acima da média podem ser justificados pela localização do posto pluviométrico, que está na vertente oceânica da Serra do Mar, a 220 metros de altitude. 
Figura 25: Distribuição anual da precipitação no posto E2-009.

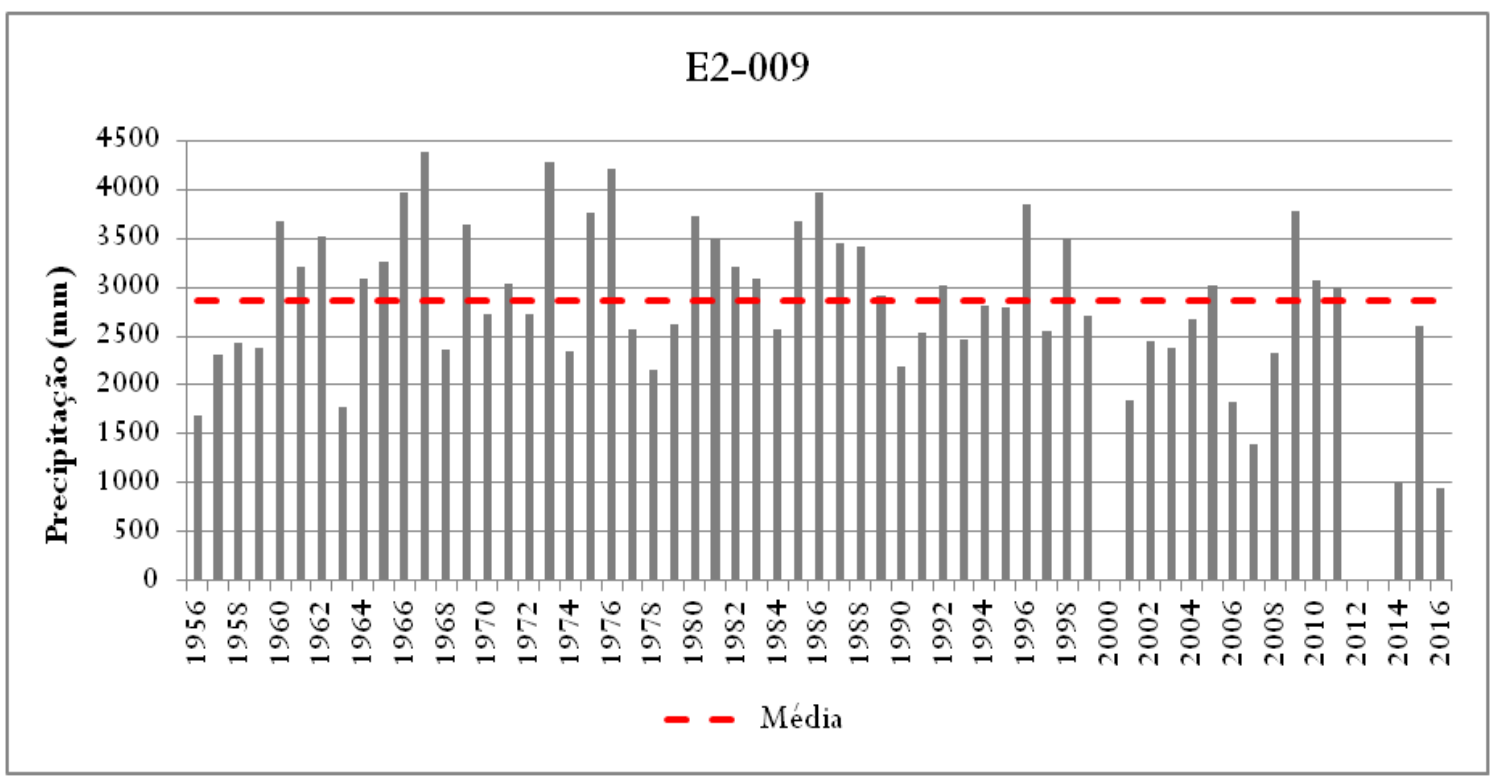

Org.: Santos, 2019.

Figura 26: Desvios absolutos em relação à média do posto E2-009.

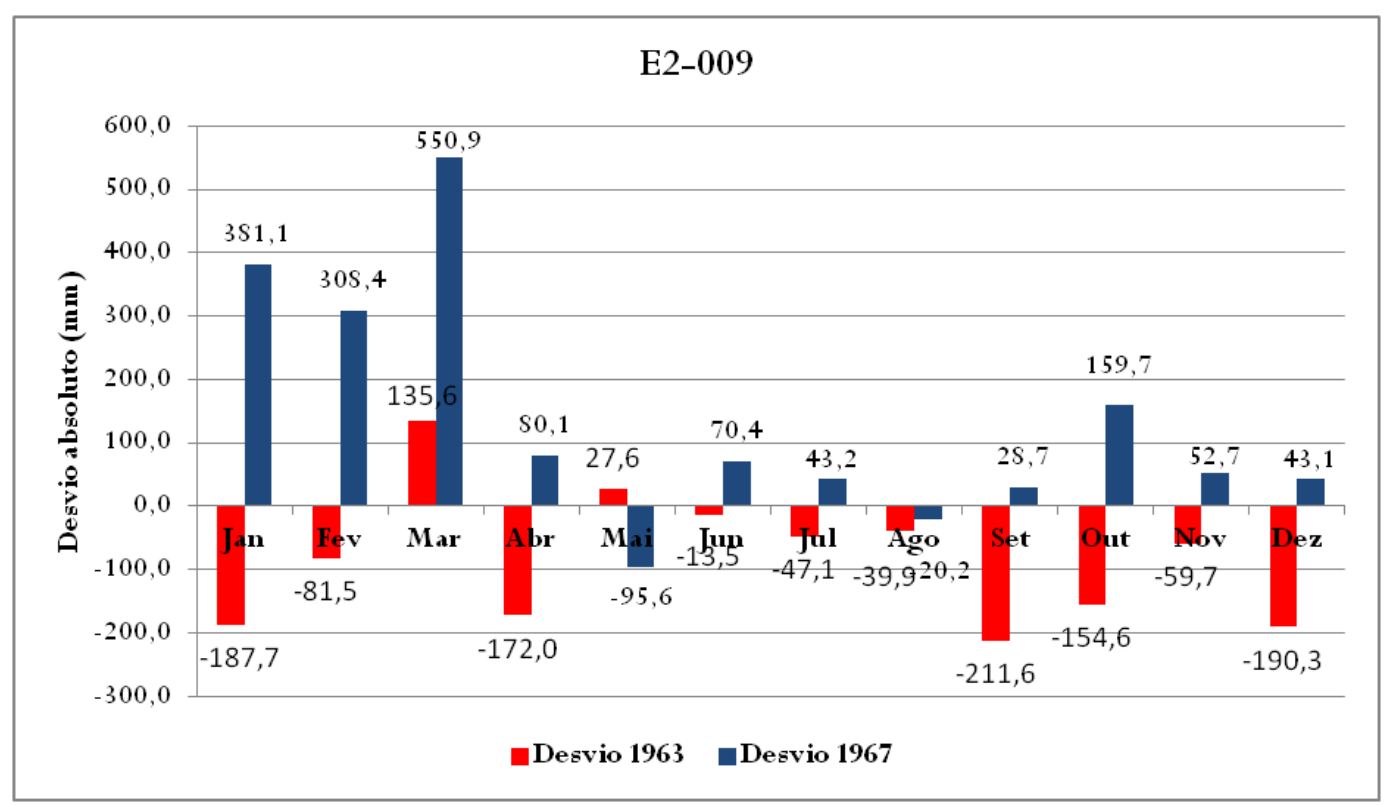

Org.: Santos, 2019.

O posto E2-052 (a 1 metro acima do nível do mar) possui registros de 1945 a 2016 e, apesar de longa, a série possui 12,9\% de falhas, o que impossibilita seu uso para fins de estudos comparativos. Está localizado no município de Ubatuba, praticamente ao nível do mar na planície costeira. A precipitação média anual foi de 2016,5 mm e o ano de maior desvio em relação à média foi o de 1966, principalmente nos meses de janeiro, abril e dezembro; e o ano de menor desvio em 
relação à média foi o de 1978, com desvios negativos distribuídos entre os meses de janeiro, março e setembro a dezembro (figuras 27 e 28).

Figura 27: Distribuição anual da precipitação no posto E2-052.

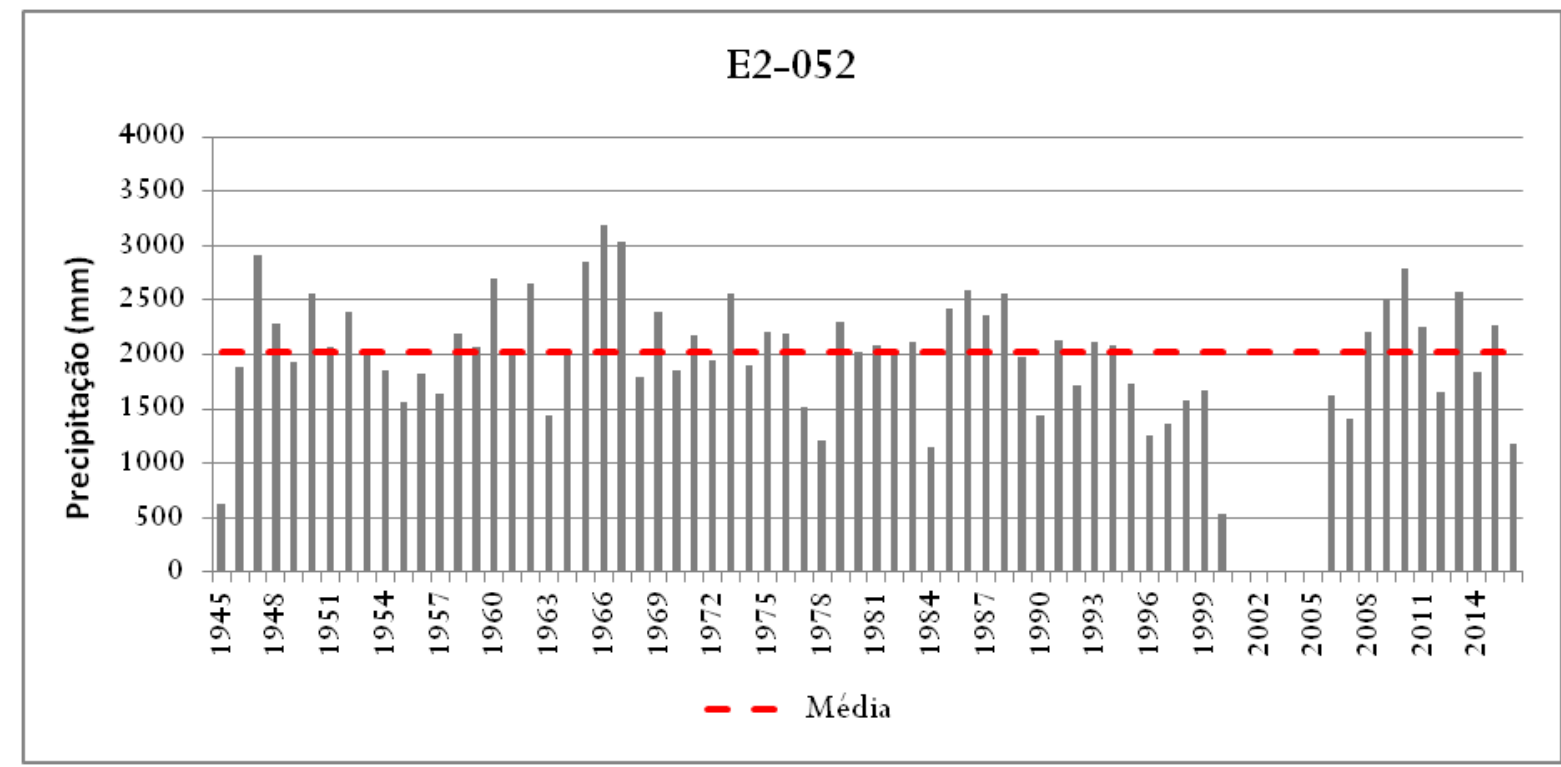

Org.: Santos, 2019.

Figura 28: Desvios absolutos em relação à média do posto E2-052.

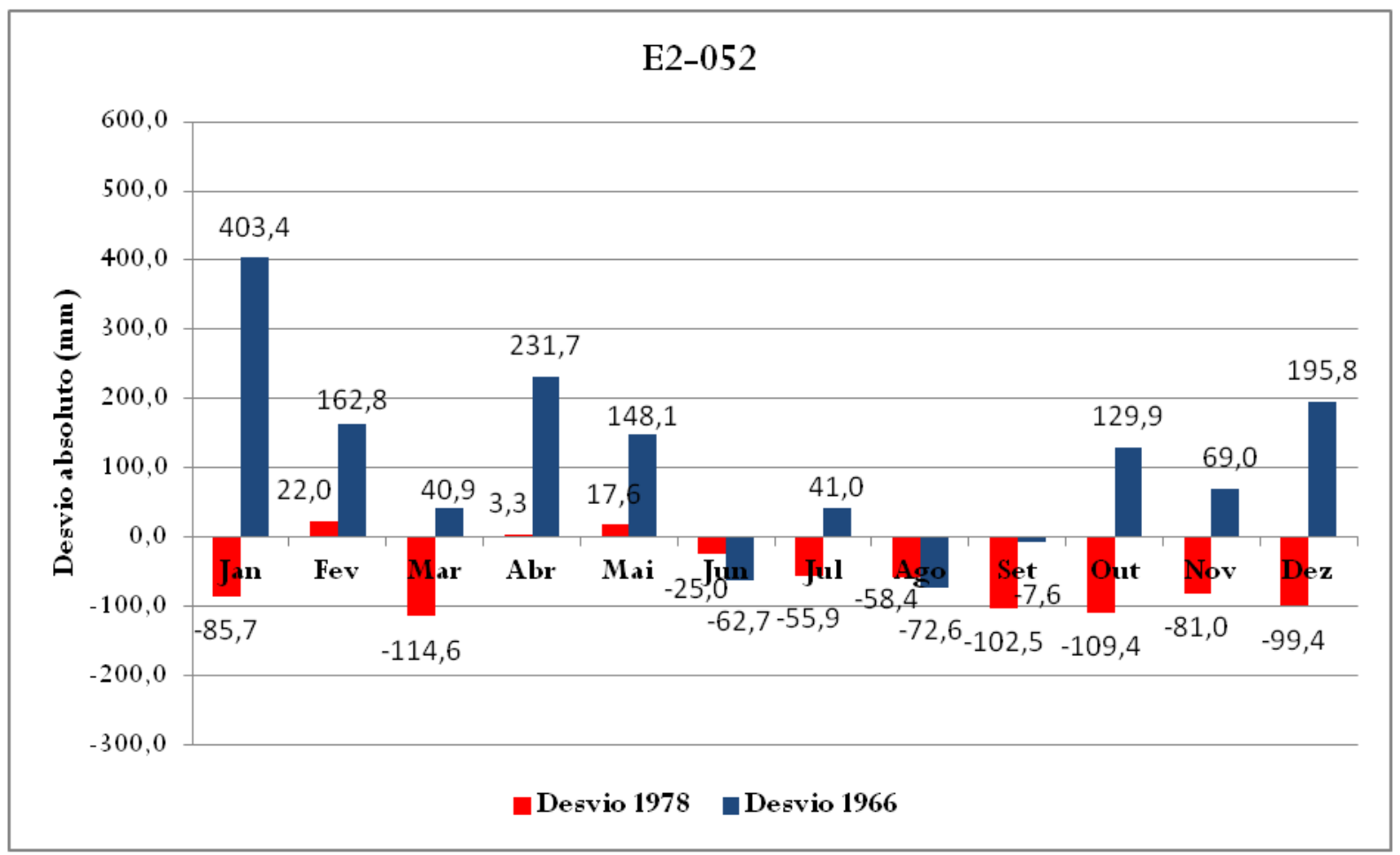

Org.: Santos, 2019.

Por fim, o posto E2-122 está localizado também na planície costeira, a 4 metros acima do nível médio do mar, na Praia de Maranduba (Ubatuba). A série histórica possui 31 anos de registro com $7,1 \%$ de falhas e apresentou média de 
precipitação de 1923,5 mm/ano. O ano de 1994 apresentou maior desvio em relação à média nos meses de fevereiro, março e abril, principalmente, e o ano de 1990 apresentou os menores desvios nos meses de janeiro, fevereiro e abril (figuras $29 \mathrm{e}$ 30). Este também será um posto utilizado como referência na análise dos eventos extremos, justificada pela sua localização geográfica.

Figura 29: Distribuição anual da precipitação no posto E2-122.

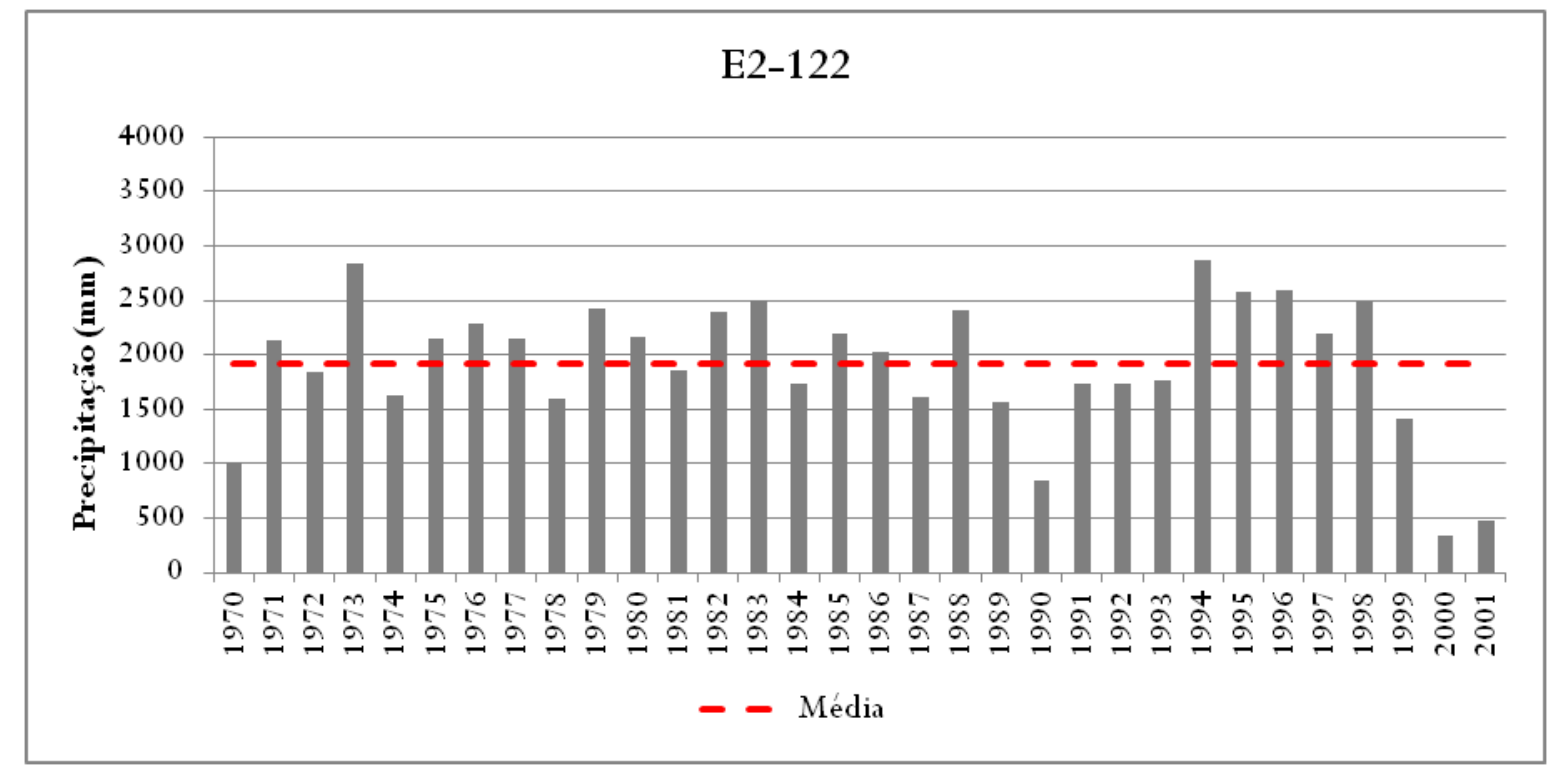

Org.: Santos, 2019.

Figura 30: Desvios absolutos em relação à média do posto E2-122.

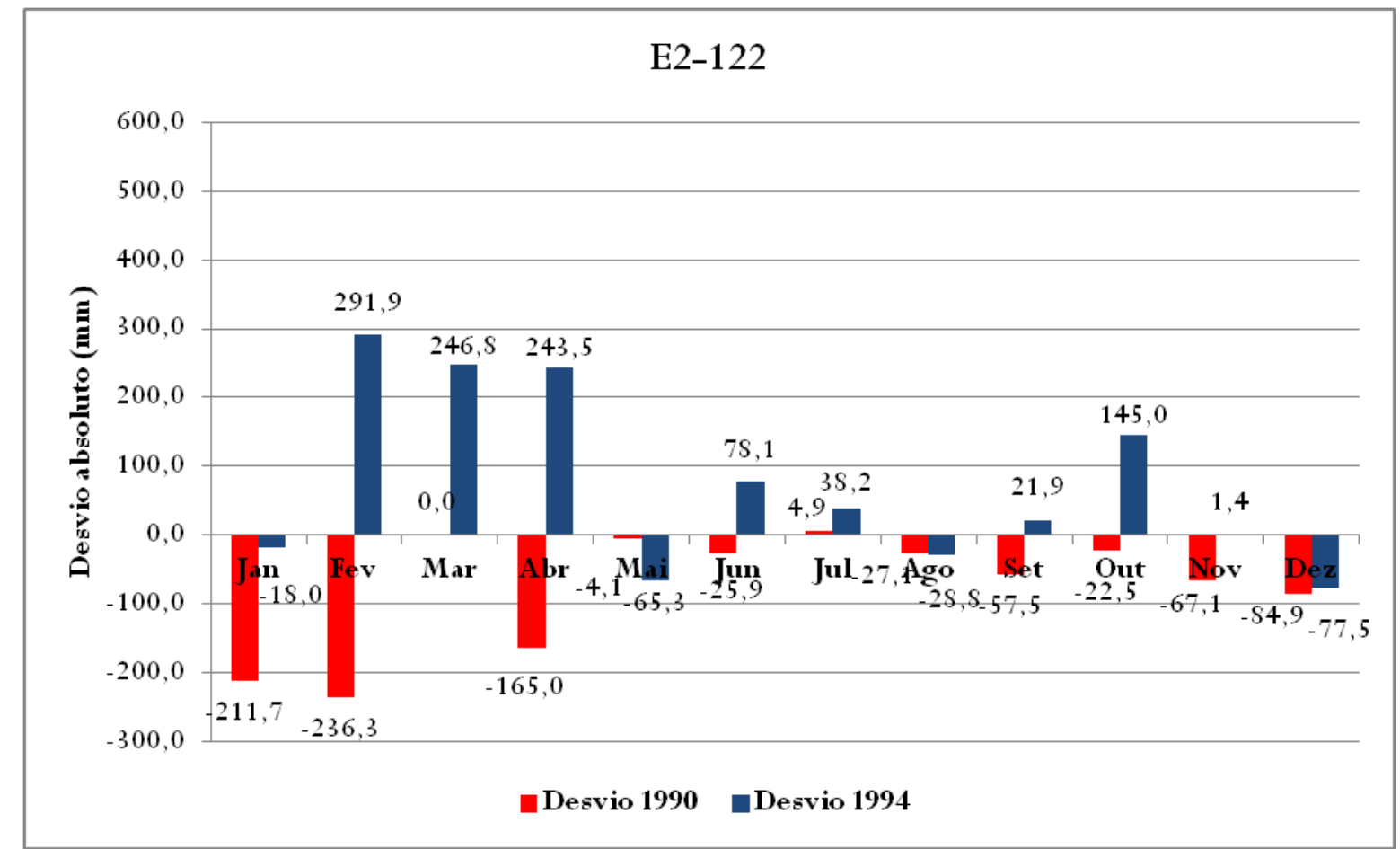

Org.: Santos, 2019. 
Ao realizar uma análise espaço-temporal das precipitações no estado do Rio de Janeiro, Sobral et al.(2018) categorizaram a área de estudo em regiões. As regiões denominadas Costa Verde (litoral sul do estado, fazendo limites com o LNP) e as baixadas litorâneas apresentaram totais de chuva anuais semelhantes aos encontrados na área de estudo da presente pesquisa. Isso ocorre porque, possivelmente, as estações meteorológicas estão localizadas à barlavento, voltadas para o Oceano Atlântico; na Costa Verde, há a presença da Serra do Mar, o que propicia a formação da chuva orográfica; há também a combinação de sistemas meteorológicos que atuam na região: ASAS, que no inverno se desloca para o Sudeste Brasileiro, ZCAS, SF, Linhas de Instabilidade, os CCM e as circulações de brisas que transportam a umidade do oceano para o continente (SOBRAL et al., 2018).

Semelhante às ocorrências de precipitações anuais de algumas regiões do estado do Rio de Janeiro, há também eventos similares na região litorânea do estado do Paraná. Segundo Terassi e Galvani (2017), a vertente oceânica da Serra do Mar neste estado possui uma pluviosidade média anual entre 2070,0 mm e $2725,0 \mathrm{~mm}$, resultado da maritimidade, atuação de sistemas atmosféricos intertropicais e a configuração do relevo, com presença de precipitações orográficas provocadas pelos ventos em superfície que divergem da ASAS e se deslocam em sentido perpendicular à área costeira, ascendendo com a presença da barreira natural que é a Serra do Mar.

\subsubsection{Análise mensal}

As figuras 31 a 33 apresentam as distribuições mensais para os nove postos pluviométricos. Observa-se que as precipitações se concentram nos meses de janeiro a março e de outubro a dezembro. Os postos E2-042 e E2-043 possuem valores médios próximos em função da sua proximidade espacial, porém estão localizados em altitudes distintas. O posto E2-128 localiza-se no bairro do Porto Novo, região sul de Caraguatatuba, que já sofre influência da sombra de chuva provocada pela llha de São Sebastião (devido sua posição geográfica e relevo) com ligeira diminuição dos seus valores médios mensais se comparado aos demais postos. Há o destaque para o posto E2-009 na qual em alguns meses os valores podem chegar a duas vezes acima das médias nos demais postos. É importante 
ressaltar que o posto pluviométrico deste município está instalado na vertente atlântica da Serra do Mar (a 220 metros acima do nível do mar), o que resulta em valores de precipitação superiores aos dos postos instalados na planície costeira. Milanesi e Galvani (2012), em um estudo sobre o efeito orográfico na llha de São Sebastião, afirmam que os pluviômetros instalados a barlavento da área de estudo registraram maiores volumes de precipitação; destes, o pluviômetro em maior altitude (600 metros acima do nível do mar) registrou $25 \%$ das chuvas no período e foi o posto mais chuvoso. Há também o fato que os valores de precipitação diária extrema influenciam no cálculo das médias, sempre "puxando" os valores para cima. Os demais postos apresentam similaridades que podem ser identificadas pela sua proximidade geográfica e/ou altitude.

Com objetivo de avaliar as precipitações no litoral paulista e correlacionar com a ocorrência de chuvas intensas e desastres naturais, Koga Vicente e Nunes (2011) concluíram que os eventos ocorrem nos meses mais chuvosos (entre primavera e verão) e, apesar da região da Baixada Santista (municípios de Santos, Guarujá, São Vicente e Praia Grande) ser a mais populosa, com maior vulnerabilidade, o Litoral Norte é mais susceptível às perdas humanas, principalmente no município de Ubatuba. Neste período, há um aumento potencial das vítimas, que coincide com a temporada de maior fluxo turístico na região, quando por vezes a população flutuante triplica em alguns municípios. 
Figura 31: Distribuição das precipitações médias mensais por posto pluviométrico.

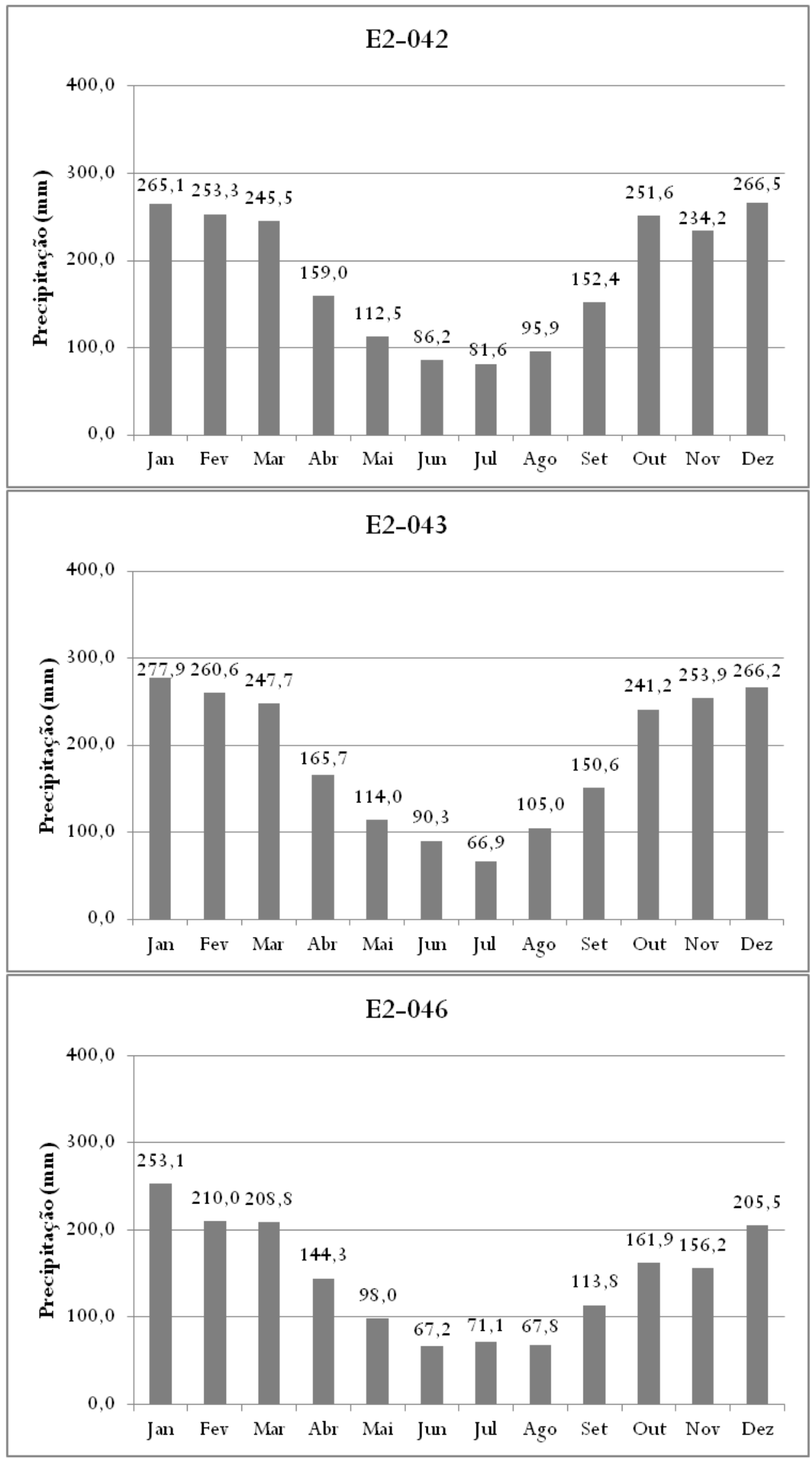

Org.: Santos, 2019. 
Figura 32: Distribuição das precipitações médias mensais por posto pluviométrico.

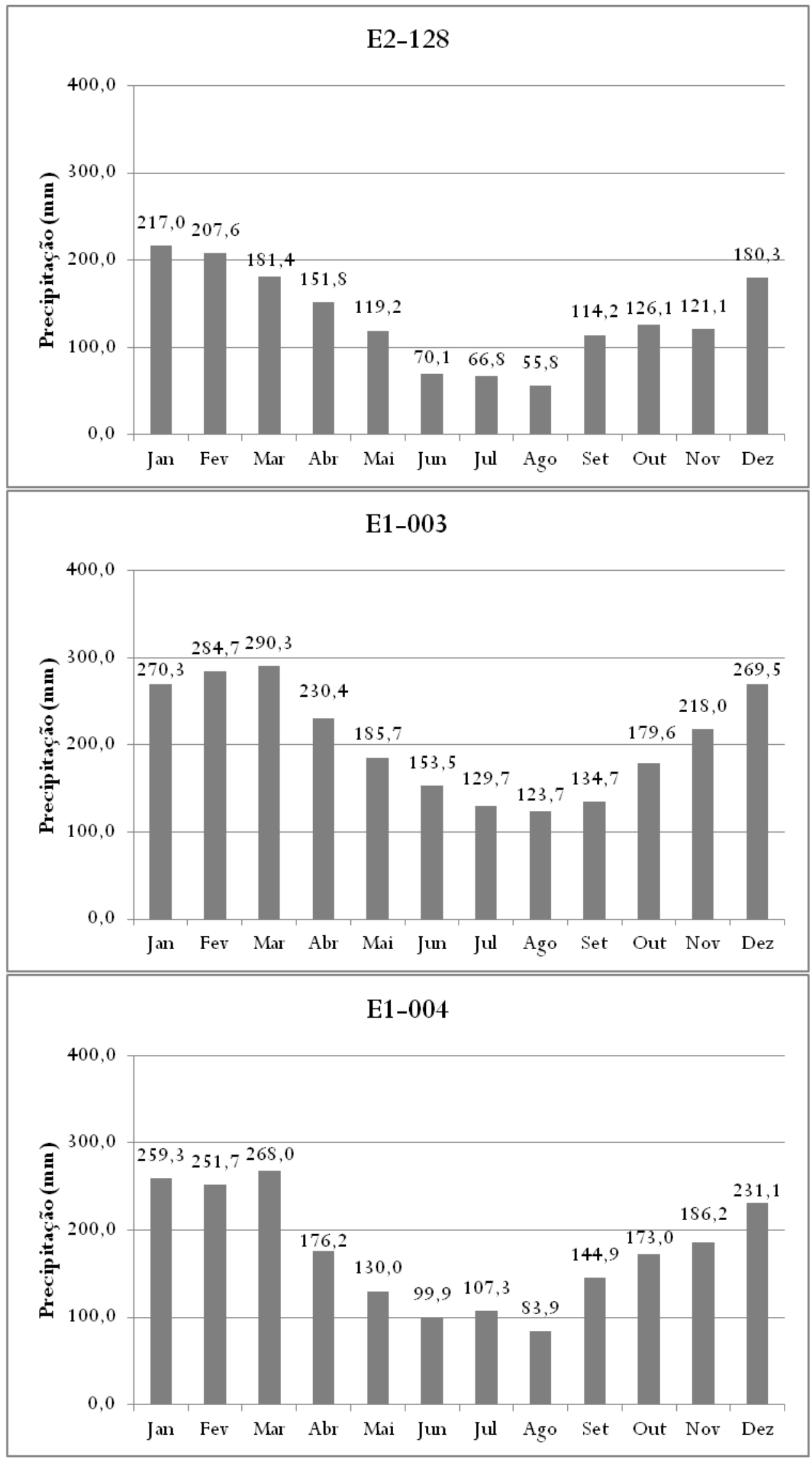

Org.: Santos, 2019. 
Figura 33: Distribuição das precipitações médias mensais por posto pluviométrico.

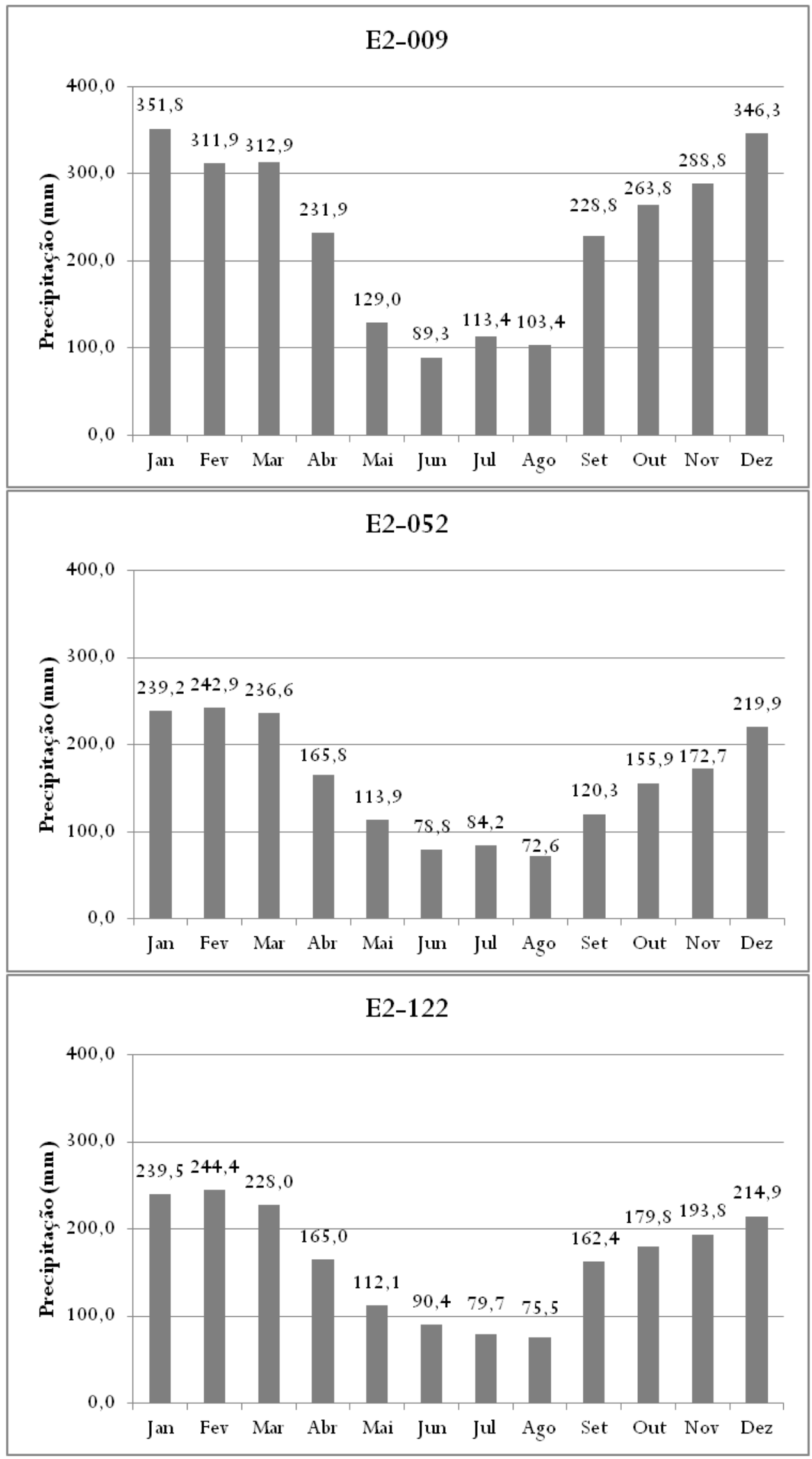

Org.: Santos, 2019. 


\subsubsection{Análise sazonal}

Trabalhos desenvolvidos na área de estudo corroboram com a distribuição sazonal das precipitações (SILVA et al, 2005; CAVALCANTI, 2012; SANTOS e GALVANI, 2014) e, para a área de estudo, está ilustrada na figura 34: em todos os postos a ocorrência durante o verão é predominante (de $35 \%$ a $38 \%$ das precipitações), seguida pela primavera (de $24 \%$ a $32 \%$ das precipitações). Nestes períodos, as precipitações são concentradas devido ao aumento de convecção e aquecimento da atmosfera, principalmente com o desenvolvimento de células de convecção que precipitam ao final da tarde e início da noite, entre os meses de dezembro e fevereiro (SANTOS; GALVANI, 2014). No Hemisfério Sul, durante esta estação, os alísios de nordeste estão mais intensos. Estes ventos transportam umidade para o interior do continente e favorecem a formação do Jato de Baixos Níveis (JBN) a leste dos Andes, que por sua vez, transporta umidade para os subtrópicos; há a possibilidade de formação da ZCOU sobre o continente. A ZCOU se estende no sentido noroeste-sudeste desde a Amazônia até o sudeste do Brasil e oceano Atlântico Sul e, quando a ZCOU atua durante três dias ou mais passa a ser denominada de ZCAS. Tanto a ZCOU quanto a ZCAS são identificadas em imagens de satélite como uma faixa de nebulosidade desde a Amazônia até o oceano Atlântico Sul (REBOITA et al, 2012; SANTOS, 2015). De acordo com Armani e Galvani (2011), no verão a ZCAS é atuante, influenciando o regime de chuvas desde a Amazônia até o sudeste do Brasil; a presença de sistemas frontais também pode contribuir para a formação da ZCAS nesta estação do ano. Durante o outono e inverno, há a redução das precipitações, que são condicionadas à passagem de frentes frias na região. Dentre os postos, de $17 \%$ a $26 \%$ das precipitações ocorreram no outono e de $13 \%$ a $16 \%$ ocorreram no inverno (figura 33 ). 
Figura 34: Distribuição percentual sazonal das precipitações em cada posto pluviométrico.

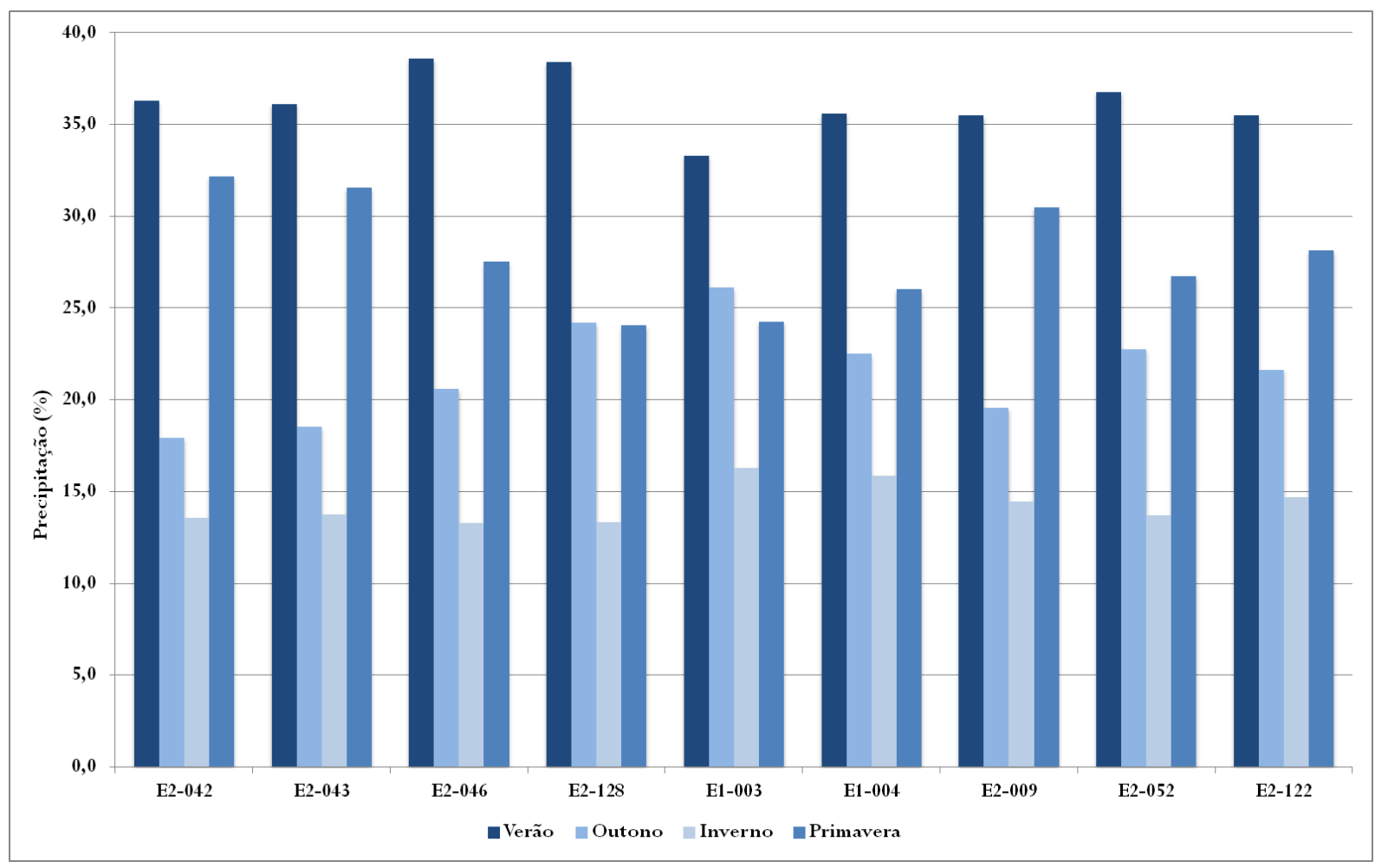

Org.: Santos, 2019.

Para a bacia litorânea no estado do Paraná, Terassi e Galvani (2017) também observaram a concentração das precipitações nos meses de primavera e verão (outubro a março, com 66,7\% das precipitações totais), com redução das precipitações nos meses de outono e inverno (abril a setembro). Para os meses de junho, julho e agosto, as precipitações foram próximas aos valores encontrados para a bacia do Ribeira, pois os sistemas atmosféricos que são responsáveis pelas chuvas em ambas as bacias neste período apresentam maior alcance e relacionamse ao deslocamento da FPA. Para a bacia hidrográfica litorânea, os valores encontrados de precipitação anual e a distribuição mensal/sazonal são próximos aos encontrados na área de estudo desta pesquisa. Assim como o litoral paulista, a zona costeira do estado do Paraná também tem seu regime pluviométrico definido pela configuração do relevo (presença da Serra do Mar) e influência da maritimidade.

\subsubsection{Análise diária}

Para a análise diária foram elaborados histogramas de frequência para cada posto pluviométrico. As classes de frequência foram definidas conforme Santos e Galvani (2014). Em todos os postos as precipitações diárias concentraram-se acima 
de $50 \%$ entre $1,0 \mathrm{~mm}$ e 10,0 mm, com exceção dos postos E1-003, E1-004 e E2122. Em seguida, a classe de $10,0 \mathrm{~mm} 30,0 \mathrm{~mm}$ foi a segunda mais frequente nos conjuntos de dados para cada posto pluviométrico. De acordo com Santos e Galvani (2014), podem-se considerar extremas as precipitações diárias com registros acima de $80,0 \mathrm{~mm}$. Ao considerar este limiar neste estudo, os postos pluviométricos apresentaram as menores frequências.

O posto E1-003 foi o que apresentou o maior percentual de precipitações acima dos 80,0 mm em 24 horas (4,2\%), seguido pelos postos E1-004 (3,9\%), E2009 (3,5\%), E2-052 (2,3\%), E2-122 (2,2\%), E2-043 (1,4\%), E2-128 (1,2\%), E2-46 $(1,1 \%)$ e E2-042 (0,8\%). Atenção ao fato que os postos com os maiores percentuais estão todos localizados no município de Ubatuba, em diversas altitudes. Os postos E1-003 e E1-004 estão próximos ao nível do mar (2 e 3 metros de altitude, respectivamente), quanto o posto em maior altitude (E2-009 a 220 metros acima do nível do mar) é apenas o terceiro com os maiores registros de precipitações diárias acima dos $80,0 \mathrm{~mm}$ (figuras 35 e 36 ).

Figura 35: Histogramas de frequência: E2-042, E2-043, E2-046 e E2-128.
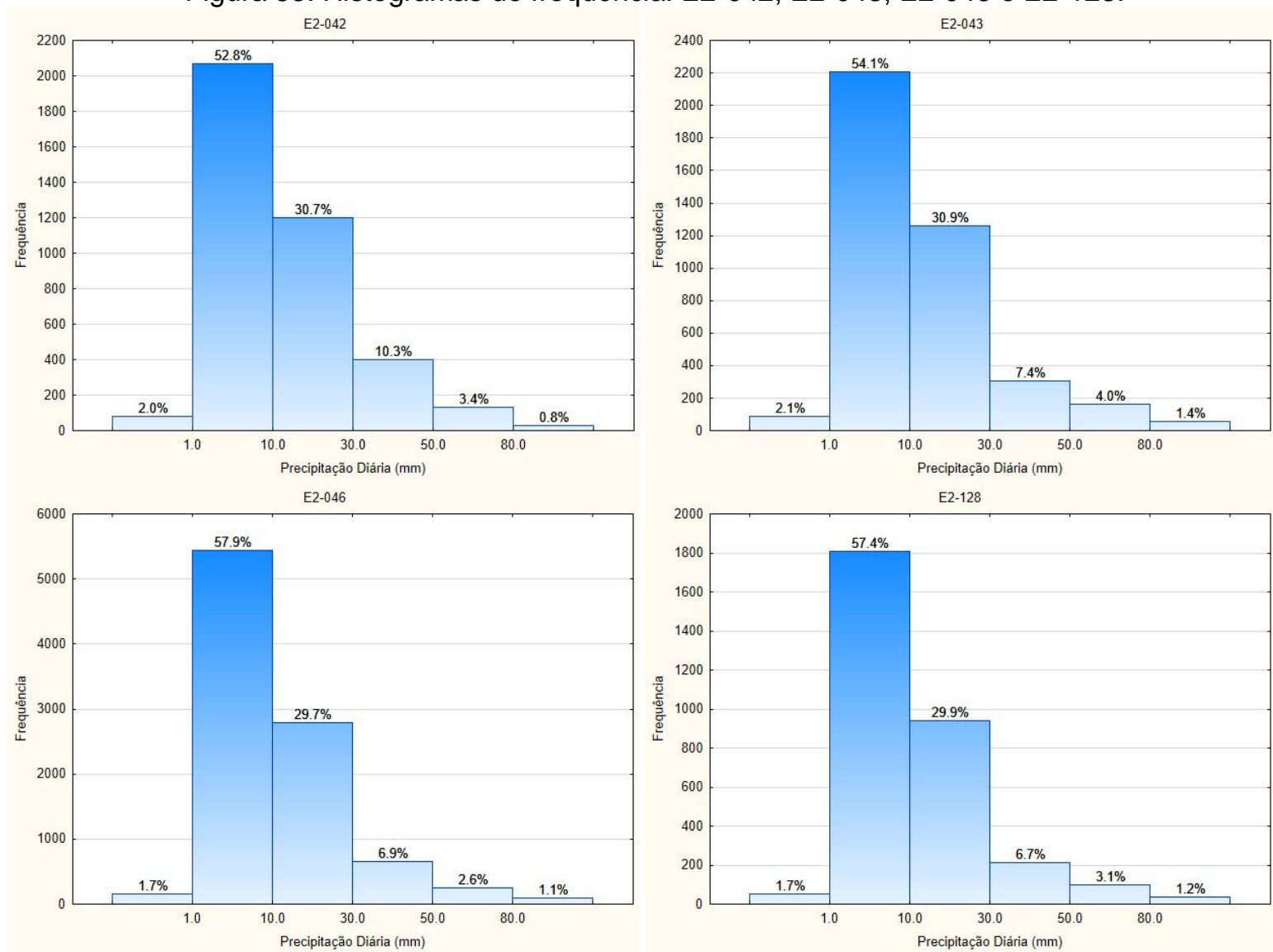

Org: Santos, 2019. 
Figura 36: Histogramas de frequência: E1-003, E1-004, E2-009, E2-052 e E2-122.
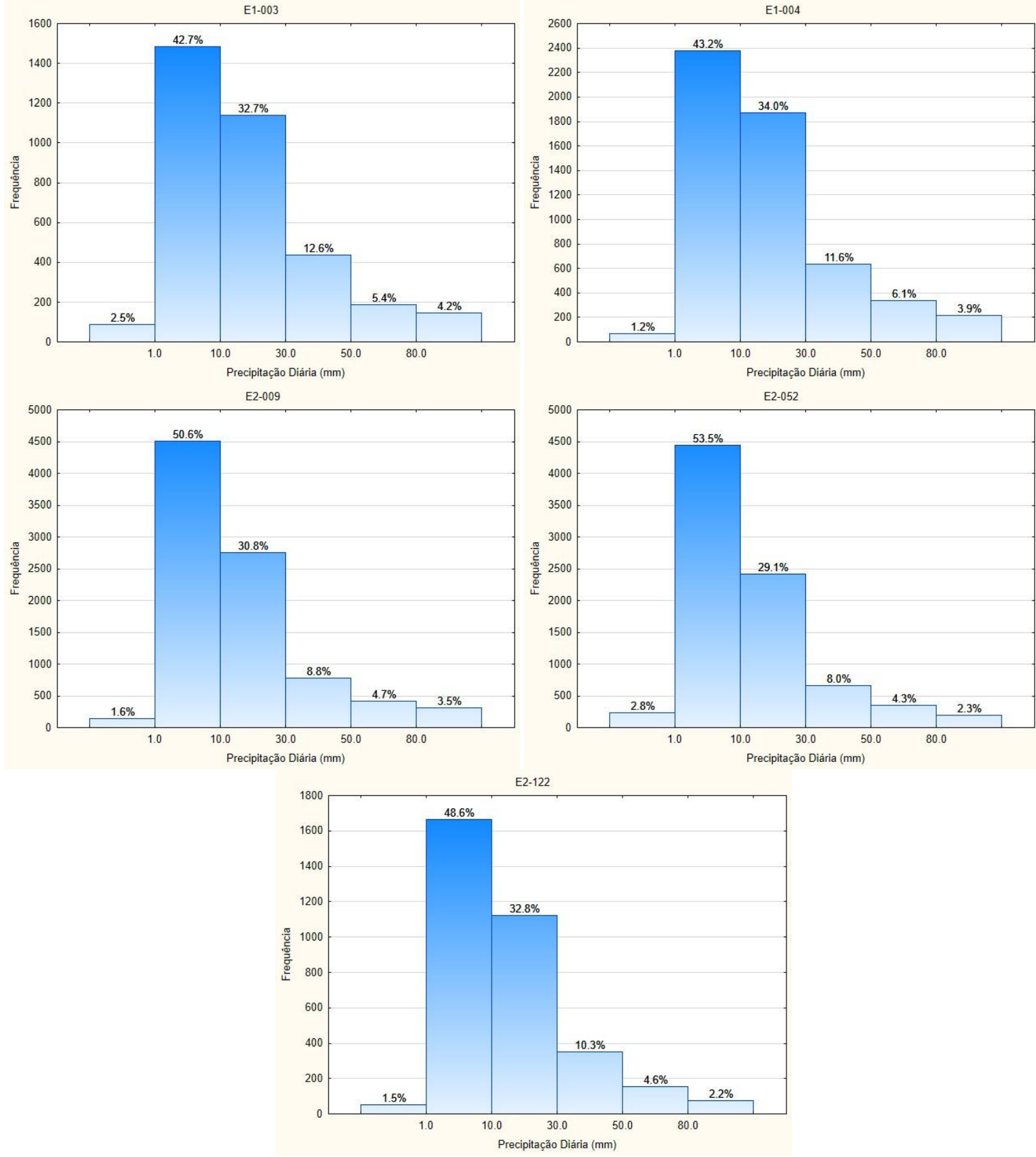

Org: Santos, 2019.

\subsection{Eventos extremos}

A tabela 6 apresenta dados estatísticos dos postos pluviométricos extraídos das análises de Box Plot. Os valores máximos de precipitação diária ultrapassaram os 200,0 mm em todos os postos e, particularmente, no posto E2-009 atingiu o valor máximo de 500,0 mm; a hipótese aceita para este valor é que ocorreu o transbordamento do pluviômetro o que possivelmente inviabilizou o registro de valores acima do suportado pelo equipamento. Para a construção dos gráficos de 
Box Plot, foram delimitados os percentis; a partir deles encontraram-se os limiares de valores extremos de precipitação diária.

Tabela 6: Dados estatísticos gerados a partir do Box Plot. Valores em mm.

\begin{tabular}{|c|c|c|c|c|c|c|c|}
\hline Posto & Dias com chuva $(\mathbf{7} \mathbf{1 , 0} \mathbf{~ m m})$ & Mediana & Mínimo & Máximo & $\begin{array}{c}\mathbf{1} \text { Quartil } \\
\mathbf{( 2 5 \% )}\end{array}$ & $\begin{array}{c}\text { 3o quartil } \\
\mathbf{( 7 5 \% )}\end{array}$ & $\begin{array}{c}\text { Extremos } \\
\mathbf{Q ( 0 , 9 9 )}\end{array}$ \\
\hline E2-042 & 3920 & 15,1 & 1,0 & 215,2 & 4,3 & 20,2 & 75,0 \\
\hline E2-043 & 4077 & 15,3 & 1,0 & 290,0 & 4,0 & 19,2 & 97,7 \\
\hline E2-046 & 9381 & 13,2 & 1,0 & 240,8 & 3,2 & 16,7 & 80,9 \\
\hline E2-128 & 3151 & 13,6 & 1,0 & 447,2 & 3,2 & 16,5 & 83,9 \\
\hline E1-003 & 3482 & 21,2 & 1,0 & 351,9 & 4,3 & 27,5 & 132,1 \\
\hline E1-004 & 5511 & 21,4 & 1,0 & 359,4 & 5,4 & 26,9 & 126,9 \\
\hline E2-009 & 8916 & 18,6 & 1,0 & 500,0 & 3,7 & 22,0 & 134,2 \\
\hline E2-052 & 8309 & 16,2 & 1,0 & 277,5 & 3,2 & 19,6 & 114,0 \\
\hline E2-122 & 3423 & 17,9 & 1,0 & 410,0 & 4,5 & 22,6 & 111,5 \\
\hline
\end{tabular}

Org.: Santos, 2019.

O posto E2-042 apresentou 39 eventos extremos no período de 1943 a 1970. De acordo com o Box Plot, os eventos considerados extremos foram aqueles com a precipitação de 75,0 mm diários (figura 37a). O verão foi o período predominante de eventos (16 ocorrências), seguido pela primavera (13 eventos), outono (7 eventos) e inverno (3 eventos). Nos percentis de ordem 5\% a 95\% estiveram as precipitações de 1,5 mm a 46,2 mm. No período de 1943 a 1971, o posto E2-043 registrou 40 eventos extremos que ocorreram acima do limiar de 97,7 mm/dia (figura 37b). Destes, 25 eventos ocorreram durante o verão, 11 na primavera e 4 no outono. Não houve registros de eventos extremos durante o inverno no período analisado. Os percentis de $5 \%$ a $95 \%$ precipitações estão entre $1,5 \mathrm{~mm}$ e $52,0 \mathrm{~mm}$, respectivamente.

Figura 37: Box Plot para os postos E2-042 (a) e E2-043 (b).
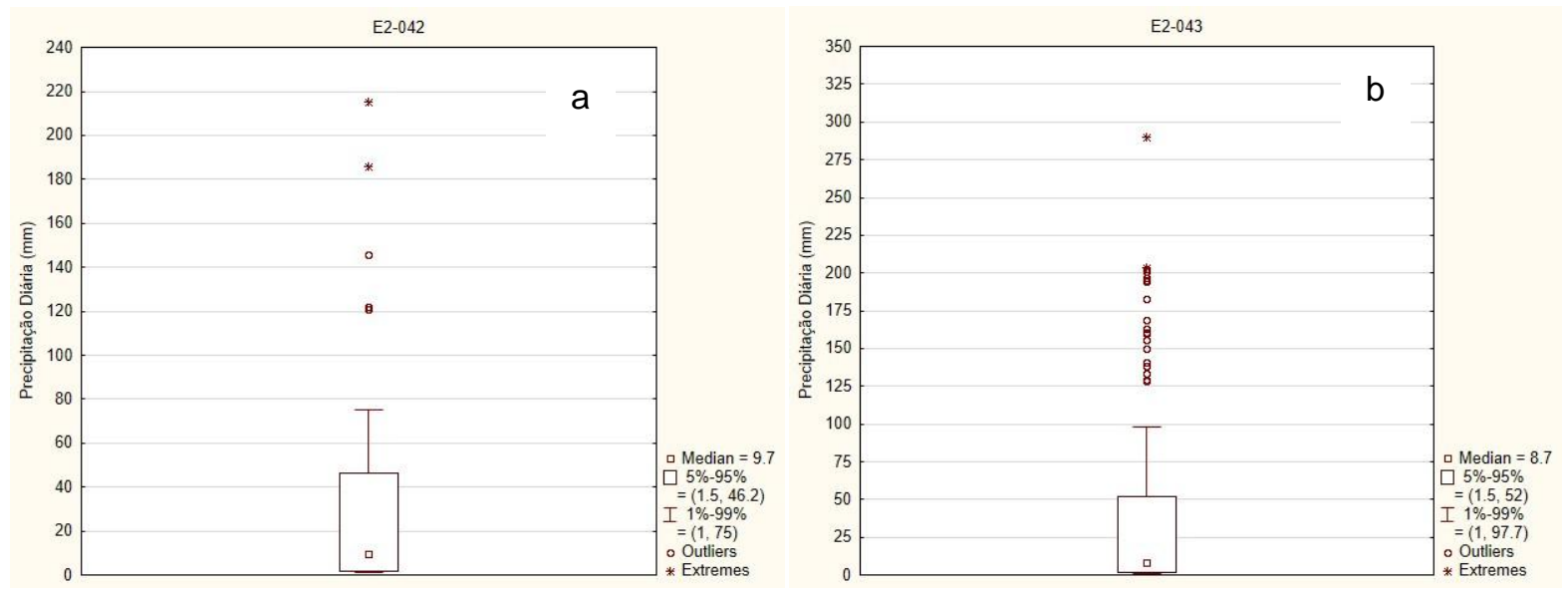

Org.: Santos, 2019. 
O Box Plot para o posto E2-046 definiu o limiar de $80,9 \mathrm{~mm} /$ dia para a ocorrência de extremos (figura 38a), os percentis de 5\% a 95\% das precipitações ficaram entre $1,3 \mathrm{~mm}$ e 43,4 $\mathrm{mm}$ e foram contabilizados 93 eventos no período de 1943 a 2014. Destes, 66 ocorreram no verão, 7 na primavera, 18 no outono e 2 no inverno. A maior ocorrência de eventos durante o outono, se comparado à primavera, pode ser justificada pela passagem de frentes frias na região. Apesar da tendência de diminuição das chuvas nesta estação, os sistemas frontais são os principais responsáveis pelas precipitações. A velocidade do deslocamento de um sistema é importante para definir a quantidade e intensidade da chuva: quanto mais lento, maior a probabilidade de ocorrência de um evento extremo (DOSWELL et al.,1996). O posto E2-128 registrou 31 eventos extremos de precipitação diária entre os anos de 1970 e 1997; 15 eventos ocorreram na estação mais chuvosa (verão) e 11 eventos no outono. A primavera e o inverno registraram apenas 2 eventos. $O$ limiar definido pelo Box Plot foi de $83,9 \mathrm{~mm} / \mathrm{dia}$, com percentis (5\% a 95\%) de 1,3 $\mathrm{mm}$ a $46,9 \mathrm{~mm}$ (figura 38b).

Figura 38: Box Plot para os postos E2-046 (a) e E2-128 (b).
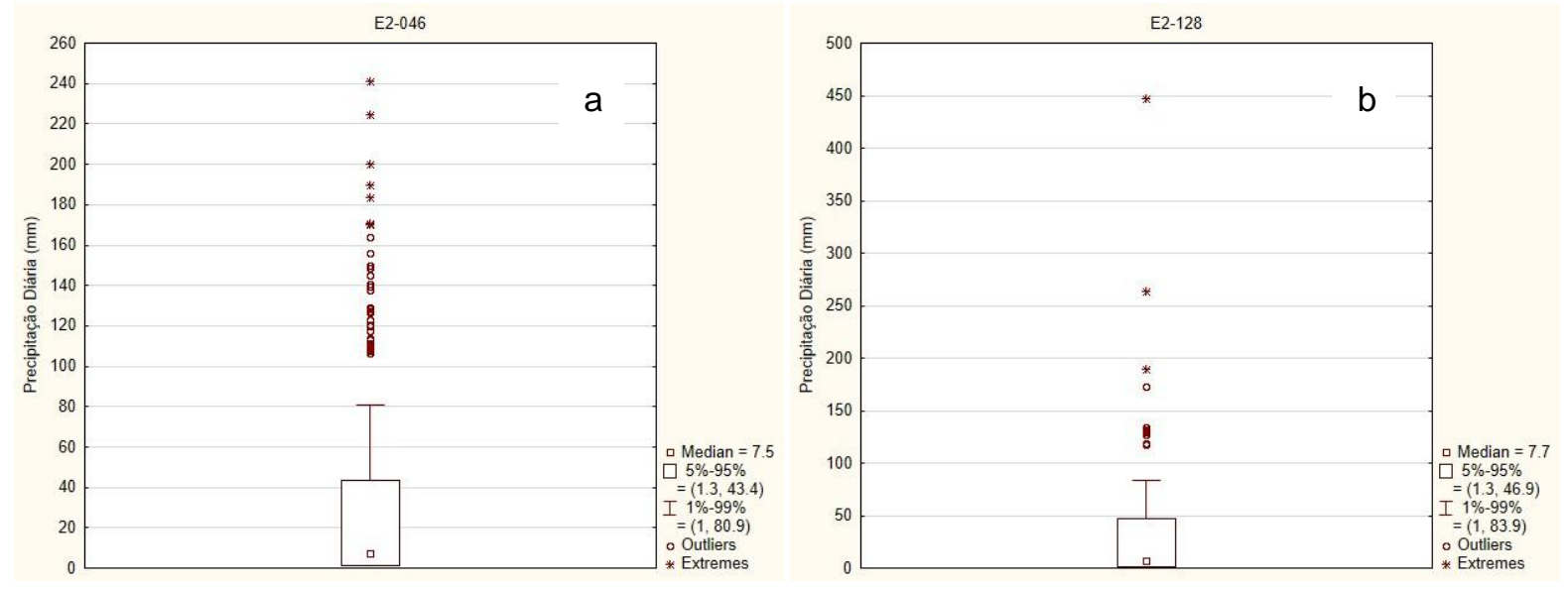

Org.: Santos, 2019.

A figura 39a apresenta o Box Plot para o posto E1-003 em 30 anos de registro (1944 a 1974); as precipitações diárias com valores acima de 132,1 mm foram consideradas extremas; já os percentis de $5 \%$ a $95 \%$ são de 1,3 mm a 73,0 mm, respectivamente. Este posto apresentou 34 eventos, 16 durante o verão e 14 durante o outono, 3 durante a primavera e apenas 1 evento no inverno. O limiar definido para a ocorrência de extremos no posto E1-004 foi de 126,9 mm/dia. Entre $5 \%$ e $95 \%$ dos dados ficaram as precipitações de 1,6 mm a 70,6 mm (figura 39b). 
Com isso, foram encontrados 32 eventos no verão, 12 no outono, 9 na primavera e 2 no inverno, considerando a série histórica do posto que corresponde aos anos de 1944 a 2000.

Figura 39: Box Plot para os postos E1-003 (a) e E1-004 (b).
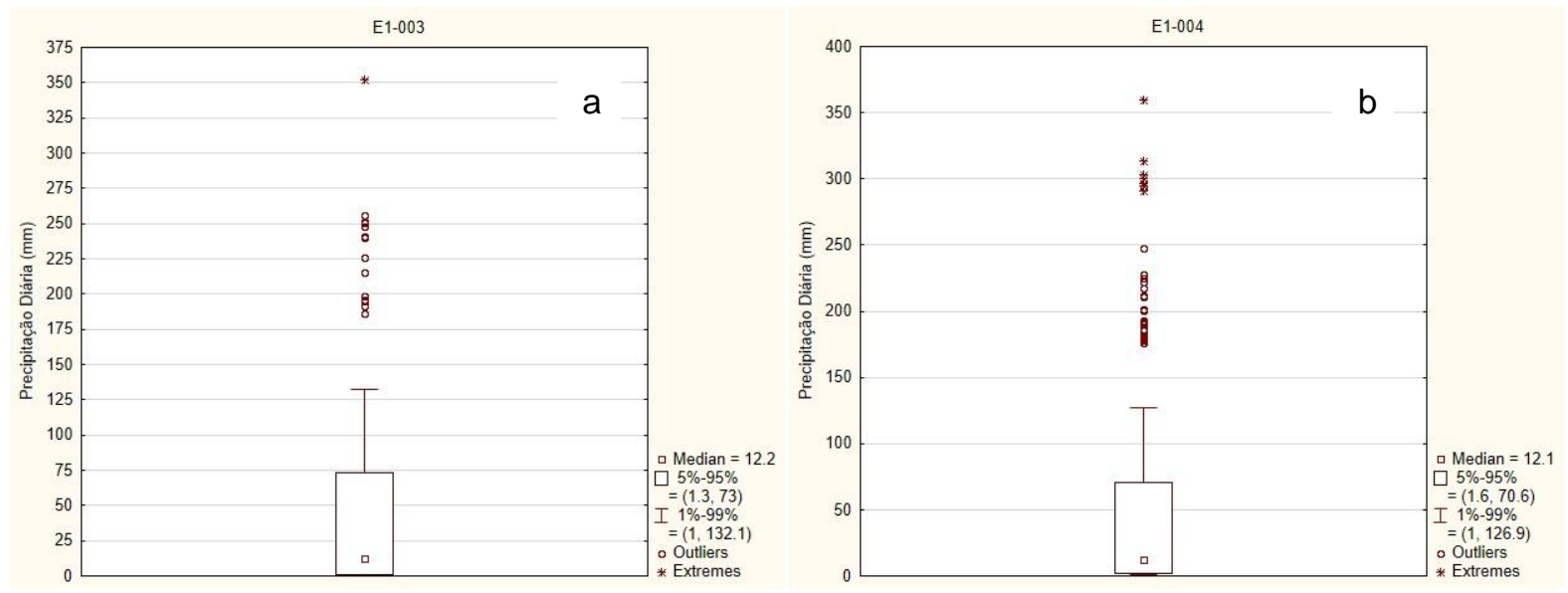

Org.: Santos, 2019.

A figura 40a ilustra o Box Plot produzido com os dados do posto E2-009. Os percentis estiveram entre $1,3 \mathrm{~mm}$ e $66,2 \mathrm{~mm}$. Foram identificados 89 eventos extremos no período de 1956 a 2016 (60 anos), sendo esta a segunda maior série histórica do estudo; 43 eventos foram registrados no verão, 22 no outono, 20 durante a primavera e 4 no inverno. O posto E2-052 apresenta a série histórica mais longa do estudo, com 71 anos de dados (de 1945 a 2016). Contudo, não possui a maior quantidade de eventos extremos (o posto E2-046 registrou o maior número). Neste posto foram identificados 83 eventos, considerando o limiar de $114,0 \mathrm{~mm} / \mathrm{dia}$; os percentis foram de $1,2 \mathrm{~mm}$ e $59,1 \mathrm{~mm}$ (figura $40 \mathrm{~b}$ ). No verão, ocorreram 47 eventos, seguido pelo outono com eventos, primavera com 14 e inverno, com 2 eventos. 
Figura 40: Box Plot para os postos E2-009 (a) e E2-052 (b).
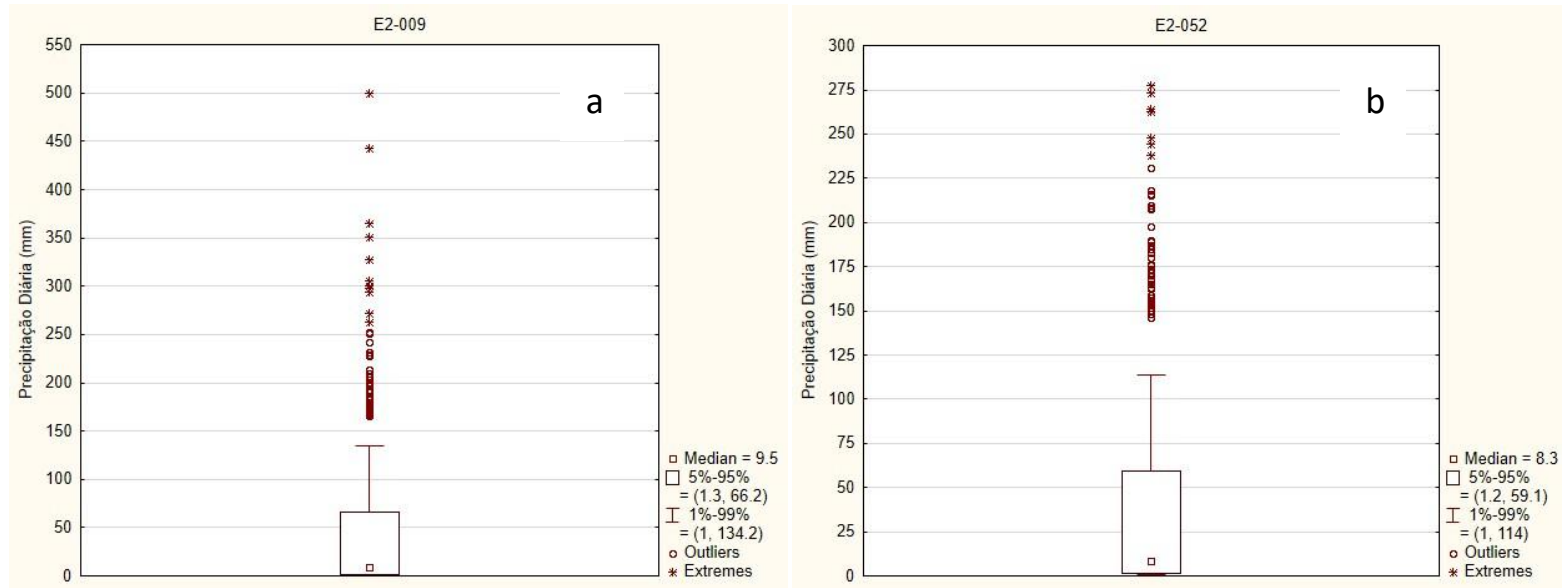

Org.: Santos, 2019.

Por fim, o posto E2-122 apresentou o registro de 34 eventos extremos no período de 1970 a 2001. O limiar definido foi de 111,5 mm de precipitação diária, com percentis de $1,5 \mathrm{~mm}$ a 56,3 $\mathrm{mm}$, conforme mostra a figura 41 . Identificou-se a ocorrência de 21 eventos no verão, 7 no outono, 5 na primavera e 1 no inverno.

Figura 41: Box Plot para o posto E2-122.

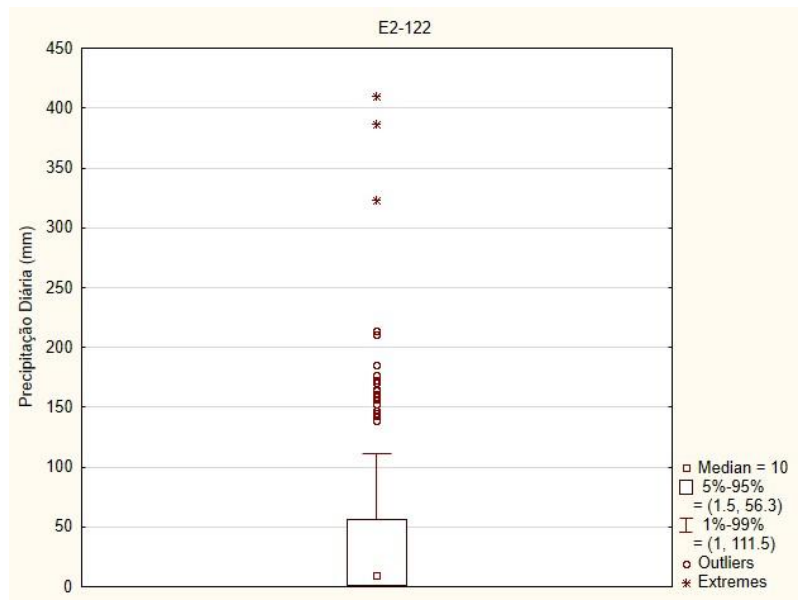

Org.: Santos, 2019.

Para o estado de Minas Gerais, Reis et al. (2018) trabalharam com o percentil de 5 a 95\% para estabelecer os eventos de precipitação extrema no período seco (abril a setembro) e período chuvoso (outubro a março). Os limiares para definição dos extremos na estação chuvosa apresentaram valores entre $36,0 \mathrm{~mm}$ e $55,0 \mathrm{~mm}$ e, na estação seca, valores entre $18,0 \mathrm{~mm}$ e $47,0 \mathrm{~mm}$, sendo que nos meses de inverno estes limiares são mais baixos. Assim como no LNP, os eventos extremos 
de precipitação em Minas Gerais ocorrem com maior frequência na estação chuvosa, porém neste estado há predominância dos eventos durante o mês de dezembro, seguido pelo mês de janeiro.

Ao comparar o limiar definido por Box Plot e o máximo diário para cada posto pluviométrico, percebeu-se que estes estiveram sempre acima dos limiares. Por exemplo, para o posto E2-128 o limiar foi de $83,9 \mathrm{~mm}$, já o valor máximo atingiu $447,2 \mathrm{~mm}$, valor 5,3 vezes maior. Para o posto E2-052, a precipitação máxima foi 2,4 vezes maior que o limiar encontrado no Box Plot. Nos demais postos, as variações entre máximos diários e limite de ocorrência de extremos foram de 2,8 a 3,0 maiores (figura 42). A ocorrência dos eventos extremos registrados em todos os postos encontra-se nos anexos (página 95).

Figura 42: Comparativo do limiar definido para o evento extremo e as ocorrências das precipitações máximas diárias (por posto).

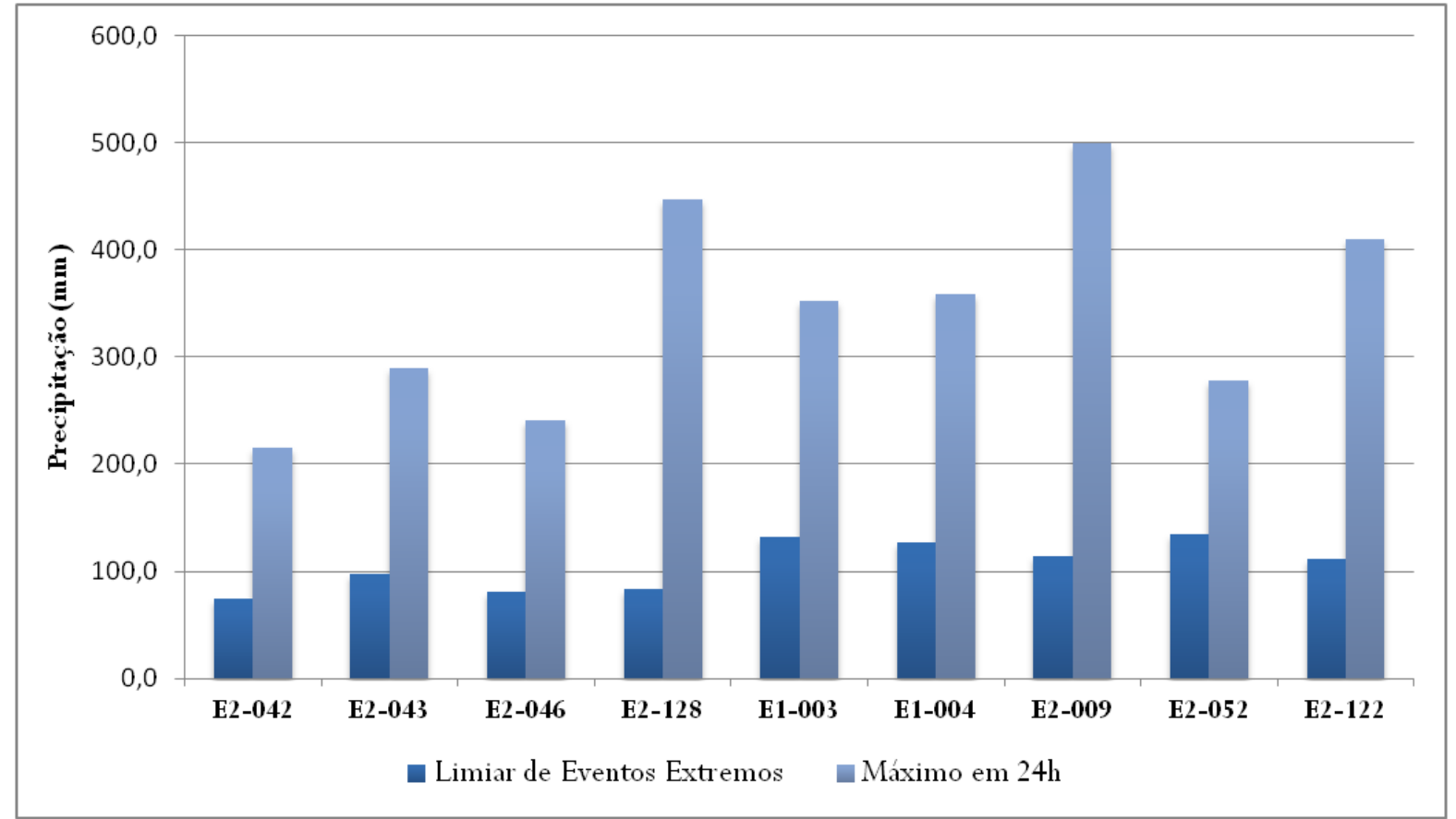

Org.: Santos, 2019.

\subsection{Comparativos de eventos extremos em três postos}

As figuras 43 a 45 apresentam o número de eventos extremos ocorridos por ano nos postos E2-046, E2-009 e E2-052, respectivamente. Em uma série histórica de 71 anos, o posto E2-046 registrou 93 eventos; o posto E2-009, com 60 anos de dados, registrou 89 eventos e o posto E2-122 registrou 34 eventos em 31 anos de 
registros pluviométricos. O maior número de eventos no posto E2-046 pode ser justificado pelo número de anos da série (é a mais longa no comparativo); já para o posto E2-009, além disso, há o fato da localização geográfica do posto, na vertente oceânica da Serra do Mar, a 220 metros de altitude. Nesta localidade há a influência da orografia na formação das precipitações diárias. Com a menor série histórica, o posto E2-122 também possui o menor número de eventos extremos registrados. Calculou-se o coeficiente de correlação (r) para verificação da existência da relação dos eventos extremos com o tempo (em anos). Para todos os postos o índice $r$ foi classificado como fraco, sendo que para os postos E2-009 e E2-122, a correlação pode ser considerada como nula dada a proximidade com o valor de zero. $\mathrm{Na}$ análise visual há a diminuição dos eventos extremos de acordo com a reta de ajuste, contudo os valores não são significativos estatisticamente (tabela 7).

Figura 43: Número de eventos extremos de precipitação por ano no posto E2-046.

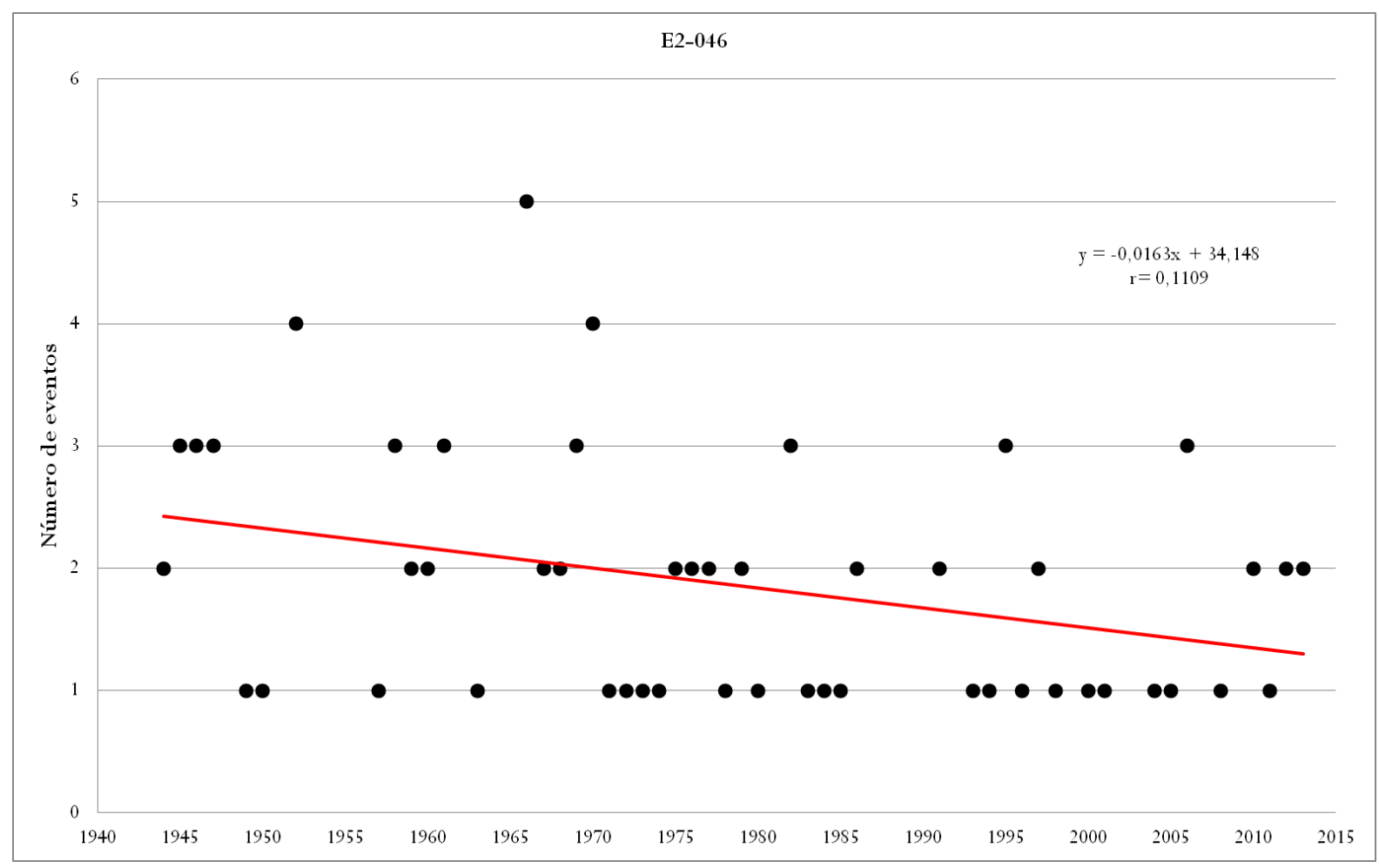

Org.: Santos, 2019. 
Figura 44: Número de eventos extremos de precipitação por ano no posto E2-009.

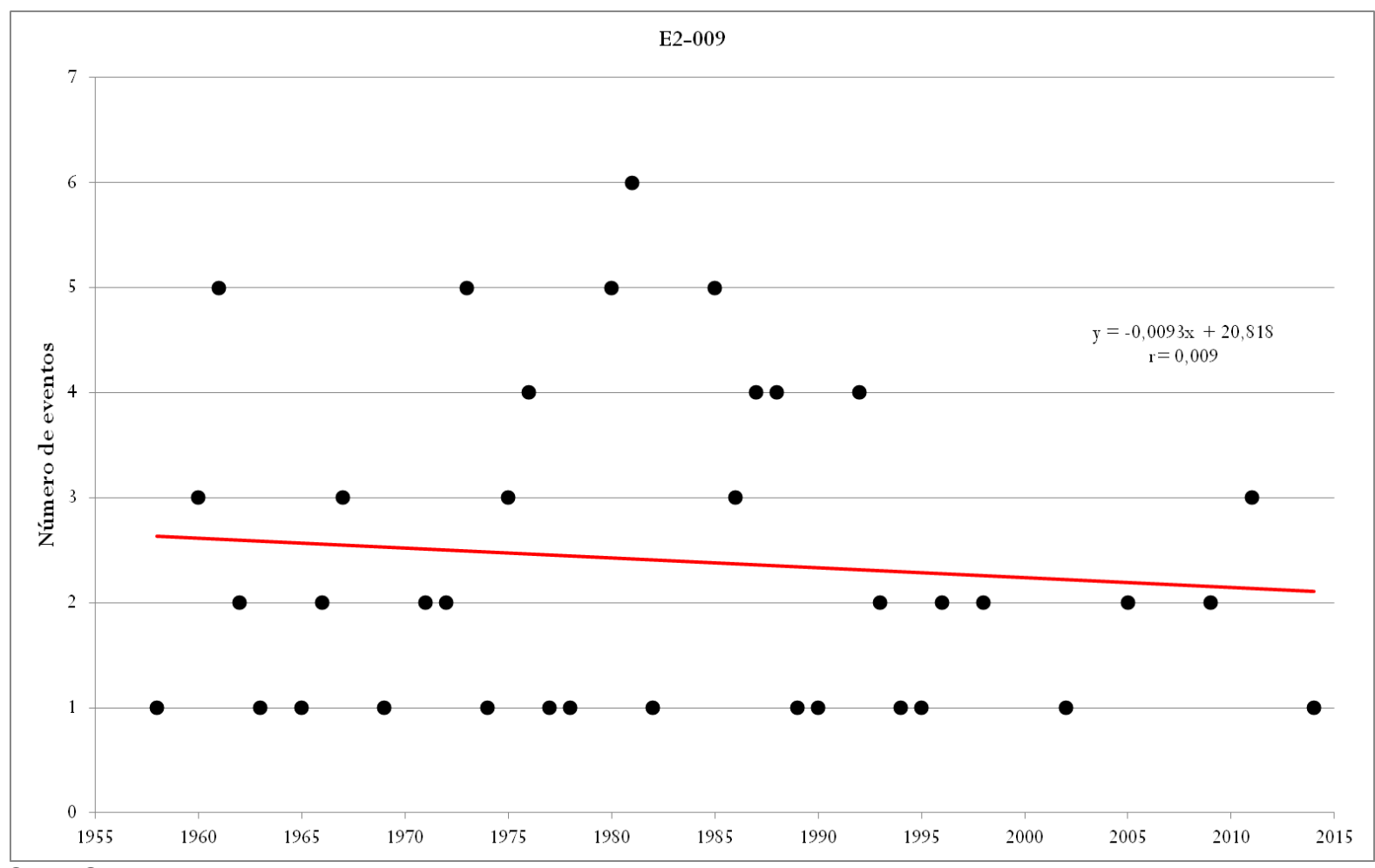

Org.: Santos, 2019.

Figura 45: Número de eventos extremos de precipitação por ano no posto E2-122.

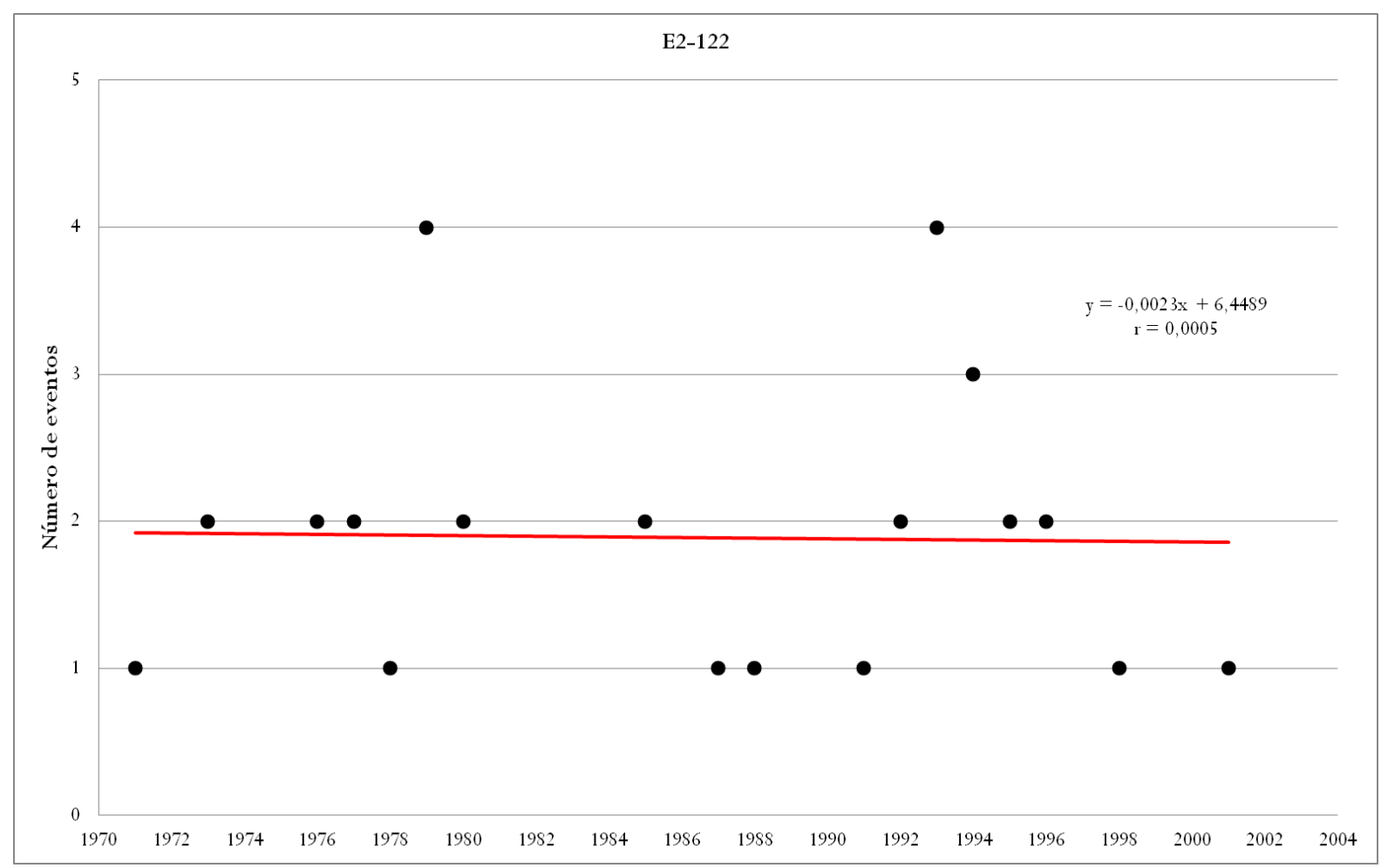

Org.: Santos, 2019. 
Tabela 7: Coeficientes de correlação entre eventos extremos de precipitação e o tempo (anos).

\begin{tabular}{c|c}
\hline Posto & Coeficiente de correlação (r) \\
\hline E2-046 & 0,1109 \\
\hline E2-009 & 0,0090 \\
\hline E2-0122 & 0,0005
\end{tabular}

Org.: Santos, $2 \overline{019}$

A análise anual dos eventos extremos também permitiu entender se, para algumas sequências de eventos, há relação com a ocorrência do fenômeno ENOS. No posto E2-046, os anos de 1952 (4 eventos), 1969 (3 eventos), 1970 (4 eventos) e 2006 (3 eventos) foram marcados pela atuação moderada do El Niño, sendo que em todos os anos da década de 1970 ocorreram eventos extremos (ao menos 1 evento ao ano), com a presença do fenômeno em sua fase forte entre os anos de 1972 e 1973. Já nos anos de 1966 (5 eventos), 1982 (3 eventos), 1997 e 1998 (2 eventos cada), o El Niño atuou em sua fase forte. Observa-se que para o ano de 1967, ano do desastre natural histórico para a região de Caraguatatuba, ocorreram apenas 2 eventos extremos na área de estudo e a atuação do ENOS foi fraca.

No posto E2-009, a atuação moderada do fenômeno ocorreu nos anos 1976 (4 eventos), 1980 (5 eventos) e 1986 (3 eventos). Nos anos de 1973 (5 eventos), 1986 (3 eventos), 1992, 1997 e 1998 (com 4 eventos cada) o El Niño foi classificado como forte. Por fim, nos demais anos a classificação foi qualificada como neutra.

Os anos de 1973, 1976 e 1977 são considerados de forte a moderada para a ocorrência do El Niño. Nestes anos, o posto E2-122 registrou 2 eventos extremos para cada um destes anos. Em 1979 ocorreram 4 eventos no período classificado como moderado e, no ano 1998, apesar da forte atuação do fenômeno, houve o registro de apenas 1 evento extremo. Ao comparar a distribuição da precipitação em quantis realizada pelo INMET $^{18}$ (figuras 46 a 48) e a ocorrência de eventos extremos com a atuação do El Niño na área de estudo, conclui-se que:

- Os anos de 1966 e 1967 foram classificados como extremamente chuvosos (El Niño forte e fraco, respectivamente);

- $\quad$ ano de 1986 foi classificado como muito chuvoso (El Niño moderado);

- Os anos de 1976 e 1979 (El Niño moderado) e 1998 (EI Niño forte) foram classificados como chuvosos;

\footnotetext{
${ }^{18}$ Séries completas disponíveis a partir de dezembro de 1962. Áreas em branco nos mapas indicam inexistência de estação meteorológica convencional. Fonte: INMET.
} 
- Os anos de 1973, 1977, 1982 e 1992 (El Niño forte), 1980 e 2006 (El Niño moderado) foram classificados como normais;

- Os anos de 1997 (El Niño forte) e 1970 (El Niño moderado) foram classificados como secos.

Figura 46: Classificação por quantis das precipitações anuais no Brasil para anos de El Niño em fase forte e com ocorrência de eventos extremos: 1966 e 1973.
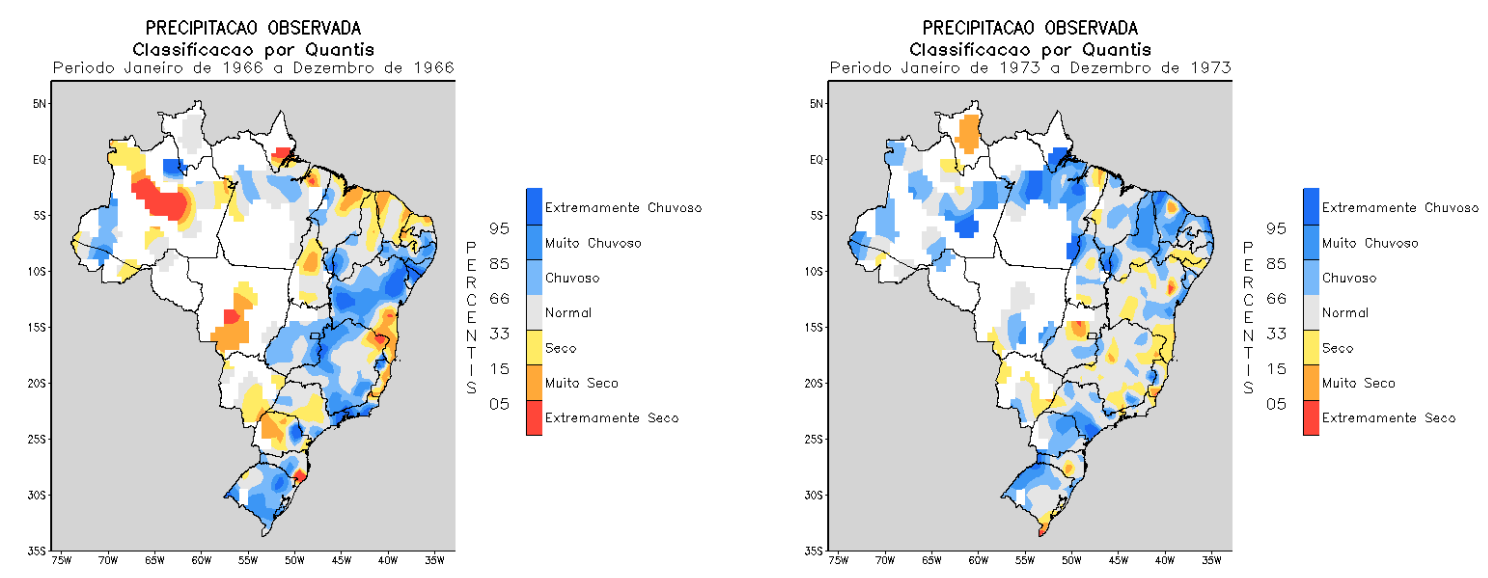

Fonte: INMET. 
Figura 47: Classificação por quantis das precipitações anuais no Brasil para anos de El Niño em fase forte e com ocorrência de eventos extremos: 1976, 1977, 1982, 1992, 1997 e 1998.
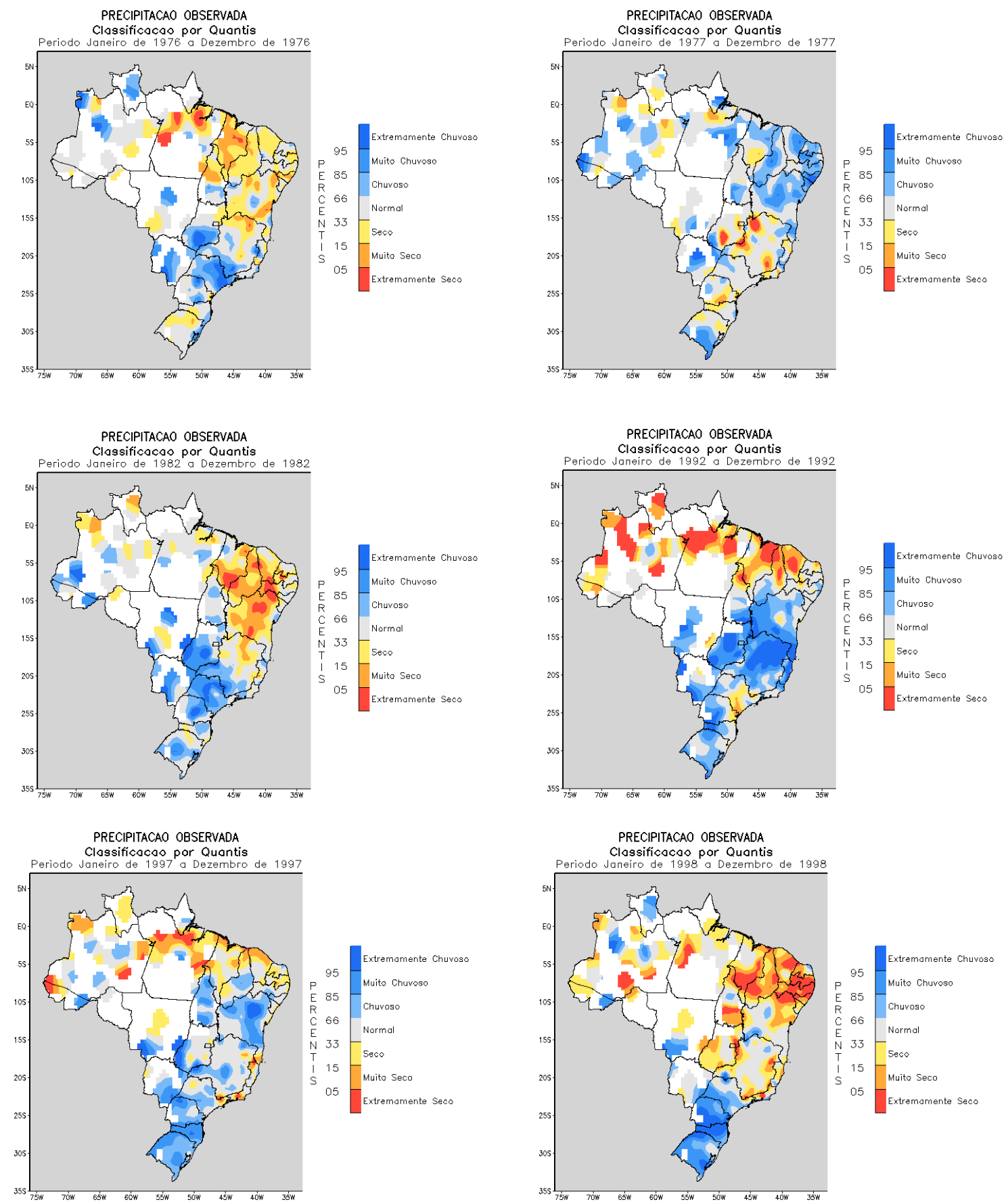

Fonte: INMET. 
Figura 48: Classificação por quantis das precipitações anuais no Brasil para anos de El Niño em fase forte e com ocorrência de eventos extremos: 1969, 1970, 1979, 1980, 1986 e 2006.
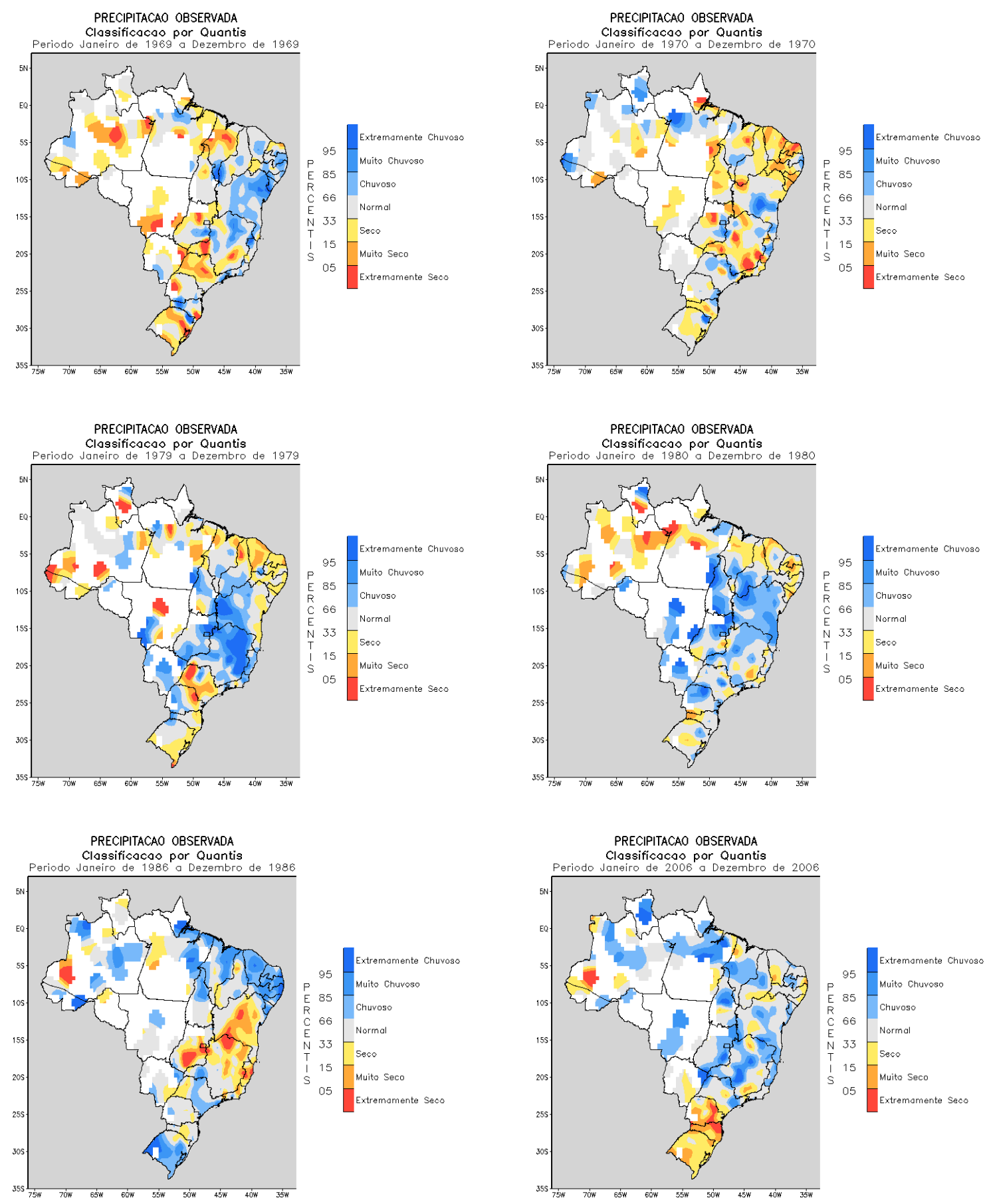

Fonte: INMET.

Para o município de Pelotas (RS), Caballero et al. (2018) também associaram a ocorrência dos extremos com a atuação do ENOS. Para o período de 1982 a 2015, foram registrados 18 eventos extremos de precipitação, que ocorreram em sua maioria durante o mês de fevereiro (verão). Nesta análise, nove eventos 
possuem relação com a presença do El Niño em suas fases muito forte (1997), forte e moderado (1983, 1987 e 2015), moderado (1998 e 2015) e fraco (2003).

A distribuição mensal dos eventos extremos nos três postos mostra que, assim como a distribuição das precipitações totais, há sazonalidade na ocorrência dos mesmos (figura 49 e tabela 8). Os eventos são predominantes nos meses de dezembro, janeiro e fevereiro (durante o verão) e diminuem a partir do mês de março (início do outono), de modo que há redução das ocorrências nos meses de inverno, inclusive com valores nulos para o mês de agosto. Armond e Sant'anna Neto (2017) também encontraram distribuição semelhante das precipitações na cidade do Rio de Janeiro, onde a ocorrência dos sistemas atmosféricos que provocam os eventos extremos atuou com maior intensidade durante a estação chuvosa.

Figura 49: Distribuição mensal dos eventos extremos (números absolutos).

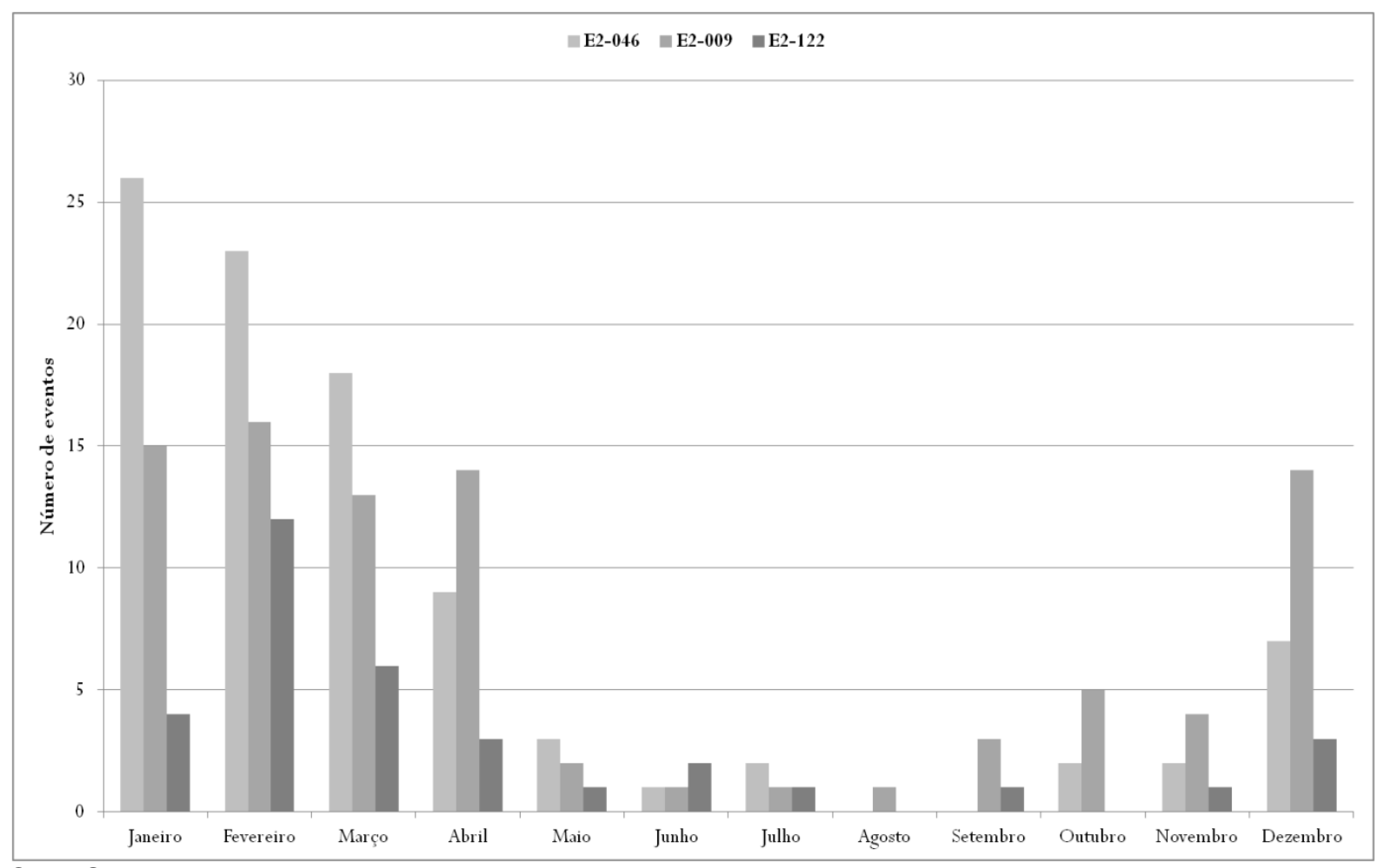

Org.: Santos, 2019. 
Tabela 8: Número de extremos de precipitação por mês (absolutos e percentuais).

\begin{tabular}{c|c|c|c|c|c} 
& E2-046 & E2-009 & E2-122 & Total Geral & $\%$ \\
\hline Janeiro & 26 & 15 & 4 & 45 & 20,8 \\
\hline Fevereiro & 23 & 16 & 12 & 51 & 23,6 \\
\hline Março & 18 & 13 & 6 & 37 & 17,1 \\
\hline Abril & 9 & 14 & 3 & 26 & 12,0 \\
\hline Maio & 3 & 2 & 1 & 6 & 2,8 \\
\hline Junho & 1 & 1 & 2 & 4 & 1,9 \\
\hline Julho & 2 & 1 & 1 & 4 & 1,9 \\
\hline Agosto & 0 & 1 & 0 & 1 & 0,5 \\
\hline Setembro & 0 & 3 & 1 & 4 & 1,9 \\
\hline Outubro & 2 & 5 & 0 & 7 & 3,2 \\
\hline Novembro & 2 & 4 & 1 & 7 & 3,2 \\
\hline Dezembro & 7 & 14 & 3 & 24 & 11,1 \\
\hline Total & 93 & 89 & 34 & 216 & 100,0 \\
\hline Sans & & & & &
\end{tabular}

Org.: Santos, 2019.

A comparação dos eventos extremos dos três postos pluviométricos mostra que o volume de chuva precipitado relaciona-se com a localização geográfica do posto, porém não necessariamente com a quantidade de eventos registrados, dado que os limiares são distintos para cada localidade. O posto E2-009, localizado a 220 metros acima do nível do mar, apresentou o maior volume precipitado diário $(500,0$ $\mathrm{mm}$ ), porém é no posto E2-046, cujo maior volume de chuva foi de $240,8 \mathrm{~mm}$, onde há o maior registro de eventos extremos no período. 


\section{CONSIDERAÇÕES FINAIS}

A localização e quantidade de dados históricos dos postos pluviométricos determinaram as análises estatísticas realizadas. As falhas apresentadas e o período dos registros permitiram o estudo individualizado de cada posto.

A análise anual mostrou que na área de estudo todos os postos pluviométricos apresentam variabilidade dos dados em relação às médias. Estas, por sua vez, têm valores que condizem com a literatura consultada, entre 1500,0 $\mathrm{mm}$ e $2500,0 \mathrm{~mm}$, para a localidade em questão, com variação de acordo com a altitude de instalação de cada posto pluviométrico.

Para a distribuição mensal e sazonal, encontraram-se valores similares aos estudo realizados para regiões de climas tropical e subtropical, visto que a área de estudo é entendida como um local de transição entre estes climas. A estação mais chuvosa é representada pela primavera e verão; durante o outono e inverno há a redução das chuvas, que não pode ser identificada como período seco, mas sim como a estação menos chuvosa.

As análises de precipitação diária apresentaram valores correspondentes aos encontrados na literatura, com valores maiores de $50 \%$ para seis dos nove postos com precipitações predominantes entre $1,0 \mathrm{~mm}$ a $10,0 \mathrm{~mm}$. A frequência de precipitações acima de $80,0 \mathrm{~mm}$ em 24 horas ficou mais evidente nos postos localizados no município de Ubatuba, com destaque para aqueles que estão na planície costeira.

A técnica estatística do Box Plot permitiu a definição dos limiares de ocorrência de eventos extremos em cada posto, dado que este tipo de análise considera a própria distribuição dos dados. O posto E2-042 obteve o menor limiar dentro do conjunto de postos $(75,0 \mathrm{~mm})$ e o posto E2-009 obteve o maior limiar $(134,2 \mathrm{~mm})$. Estes valores refletem a realidade dos volumes máximos de chuva precipitado em um dia (24 horas) para cada posto.

A seleção dos três postos pluviométricos (E2-046, E2-009 e E2-122) obedeceu ao critério de selecionar as séries históricas com o menor número de falhas e sua localização geográfica de acordo com a altitude. Os postos que apresentam o maior número de eventos são aqueles que possuem a série histórica mais longa, em ordem decrescente: E2-046 com 93 eventos (71 anos de dados), E2- 
009 com 89 eventos (60 anos de dados) e E2-122 com 34 eventos (31 anos de dados).

Os índices de correlação ( $r$ ) para todos os postos apresentaram-se fracos, sendo que para os postos E2-009 e E2-122 podem ser considerados nulos. Isto significa que há fraca (ou nula) correlação entre os eventos extremos e os anos analisados em cada posto pluviométrico.

A comparação entre a ocorrência dos eventos e o fenômeno ENOS mostra que nos anos em que o El Niño esteve em sua fase forte e/ou moderada, houve registros de três ou mais eventos extremos de chuva para os postos selecionados. Porém, para o ano de 1967, quando ocorreu um dos maiores desastres naturais da zona costeira do estado de São Paulo, a atuação do El Niño foi identificada como fraca. Os 240,8 $\mathrm{mm}$ precipitados no posto E2-046 (máximo para esta localidade) podem ser justificados pela atuação de outros sistemas atmosféricos como ZCAS, SF, etc.

Acompanhando a distribuição das precipitações mensais totais e médias, os eventos extremos também apresentam sazonalidade em sua ocorrência, com predominância durante a primavera e o verão. A redução dos eventos inicia-se durante os meses de outono e inverno, inclusive com ausência de eventos extremos no mês de agosto.

O estudo dos eventos extremos nos três postos permitiu concluir que a ocorrência dos mesmos depende da localização geográfica em que são realizados os registros, pois as características locais de relevo (altitude e orientação, por exemplo) influenciam no volume de chuva captado pelo pluviômetro. Em relação aos valores médios e registro de eventos extremos, o posto E2-009 obteve destaque com os maiores valores, dado sua altitude que permite a captação das precipitações orográficas. Contudo, para efeitos de planejamento e prevenção de desastres, este posto somente é indicado para a tomada de decisões em locais inseridos na sua cota altimétrica (220 metros) e com a mesma ocupação do solo. Os postos E2-046 e E2-122, localizados na área urbana de Caraguatatuba e Ubatuba, respectivamente, oferecem subsídios para o planejamento urbano quando este tem o objetivo de diminuir ou cessar os impactos à população em caso de ocorrência de desastres naturais provocados por um evento extremo de chuva. Nota-se que a localização dos postos, na planície costeira, deve ser considerada em conjunto com outros fatores como quantidade de pessoas nas habitações, declividade, tipo de solos, etc. 
Esta pesquisa apresentou limitações, dada a interrupção parcial ou total dos registros nos pluviômetros convencionais, causada por diversas circunstâncias como ausência do observador, falhas no equipamento, finalização do posto por parte do órgão responsável, entre outros. A rede de cobertura dos postos pluviométricos em relação à área de estudo também foi um fator limitante, conforme sua dimensão espacial e diversidade geomorfológica.

A definição de eventos extremos de precipitação é relevante pela dificuldade de previsão de desastres naturais causados pela chuva, pois a área de estudo possui alta susceptibilidade aos escorregamentos e inundações. Com este trabalho foi possível compreender que há a necessidade de unificação das metodologias de coleta, registro e análise dos dados climáticos para que haja também a padronização na determinação do que são e como ocorrem os eventos extremos de precipitação no Litoral Norte Paulista. 


\section{REFERÊNCIAS}

AB'SÁBER, A.N. Contribuição à geomorfologia do litoral paulista. Revista Brasileira de Geografia, Rio de Janeiro, v. 17, n. 1, p. 3-48, mar. 1955.

AB'SÁBER, A.N. Os domínios de natureza no Brasil: potencialidades paisagísticas. São Paulo: Ateliê Editorial, 2003, 159 p.

ALMEIDA, F. F. M. Fundamentos Geológicos do Relêvo Paulista. Série Teses e Monografias, IGEOG-USP, São Paulo, n. 14, 99 p., 1974.

ALMEIDA, F.F.M; CARNEIRO, C.R. Origem e evolução da Serra do Mar. Revista Brasileira de Geociências, v. 28, p.135-150, 1998.

ALVAREZ, C.A.; STAPE, J.L.; SENTELHAS, P.C.; GONÇALVES, J.L. de M.; SPAROVEK, G. 2014. Koppen's climate classification map for Brazil. Meteorologische Zeitschrift, 22: 711-728.

ANTUNES, A. S. Fenômenos de precipitação pluvial intensa: análise da espacialidade e variabilidade na bacia hidrográfica do Rio Piracicaba-SP. Dissertação (mestrado). Faculdade de Filosofia, Letras e Ciências Humanas, Universidade de São Paulo, São Paulo, 2015.

ARMANI, Gustavo; GALVANI, Emerson. Fluxos polares e o ritmo dos sistemas atmosféricos no nordeste do Estado de São Paulo. Soc. nat. (Online), Uberlândia , v. 23, n. 1, p. 7-22, 2011 Disponível em http://www.scielo.br/scielo.php?script=sci_arttext\&pid=S198245132011000100002\& $\mathrm{ng}=\mathrm{pt \& nrm}=$ iso. Acesso em 11 dez. 2017. http://dx.doi.org/10.1590/S198245132011000100002.

ARMOND, Núbia Beray; SANT'ANNA NETO, João Lima. ENTRE EVENTOS E EPISÓDIOS: RITMO CLIMÁTICO E EXCEPCIONALIDADE PARA UMA ABORDAGEM GEOGRÁFICA DO CLIMA NO MUNICÍPIO DO RIO DE JANEIRO. Revista Brasileira de Climatologia, [S.I.], v. 20, ago. 2017. ISSN 2237-8642. Disponível em: https://revistas.ufpr.br/revistaabclima/article/view/49792. Acesso em: 04 maio 2019. doi:http://dx.doi.org/10.5380/abclima.v20i0.49792.

ARRUDA, Karlla Emmanuelle Cunha; GARCIA, Maria da Glória Motta; DEL LAMA, Eliane Aparecida. Inventário Geológico do Patrimônio Construído no Litoral Norte do Estado de São Paulo, Brasil. Boletim Paranaense de Geociências, [S.I.], v. 73, n. 1, jul. 2017. ISSN 0067-964X. Disponível em: http://revistas.ufpr.br/geociencias/article/view/50120/32807. Acesso em: 03 nov. 2017. doi:http://dx.doi.org/10.5380/geo.v73i1.50120.

AYOADE, J. O. Introdução à Climatologia para os Trópicos. Tradução de Maria

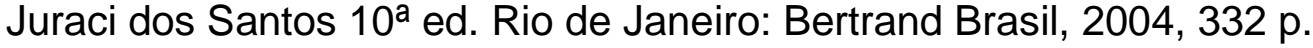

BACHIR, H.; SEMAR, A.; MAZARI, A. Statistical and geostatistical analysis related to geographical parameters for spatial and temporal representation of rainfall in semiarid environments: the case of Algeria. Arabian Journal of Geosciences, v.9, ed. 7, 
2016. Disponível em: http://link.springer.com/article/10.1007/s12517-016-2505-8. Acesso em 11 de dezembro de 2017. DOI: 10.1007/s12517-016-2505-8.

BARI, S.H.; RAHMAN, M.T.U.; HOQUE, M.A.; HUSSAIN, M.M. Analysis of seasonal and annual rainfall trends in the northern region of Bangladesh. Atmospheric Research, v.176-177, p. 148-158, 2016. Disponível em: http://www.sciencedirect.com/science/article/pii/S0169809516300254. Acesso em 11 de dezembro de 2017. http://dx.doi.org/10.1016/j.atmosres.2016.02.008.

BARROS, Juliana Ramalho; ZAVATTINI, João Afonso. BASES CONCEITUAIS EM CLIMATOLOGIA GEOGRÁFICA (the conceptual bases in geographical climatology). Mercator, Fortaleza, v.8, n.16, p. 255 a 261, oct. 2009. ISSN 1984-2201. Avaliable at: http://www.mercator.ufc.br/mercator/article/view/289. Date accessed: 08 sep. 2018.

BARRY, R. G.; CHORLEY, R. J. Atmosphere, Weather and Climate. $8^{\mathrm{a}}$ ed. London: Routledge, 2003, $421 \mathrm{p}$.

BORSATO, Victor da Assunção; MENDONÇA, Francisco de Assis. PARTICIPAÇÃO DA MASSA POLAR ATLÂNTICA NA DINÂMICA DOS SISTEMAS ATMOSFÉRICOS NO CENTRO SUL DO BRASIL (Participation of the Atlantic polar mass in the dynamics of the atmospheric systems in Brazil's South Center). Mercator, Fortaleza, v. 14, n. 1, p. 113 a 130, apr. 2015. ISSN 1984-2201. Available at: http://www.mercator.ufc.br/mercator/article/view/1003. Date accessed: 03 may 2019.

CABALLERO, Cassia Brocca et al. A precipitação pluviométrica em Pelotas/RS: tendência, sistemas sinóticos associados e influência da ODP (The rainfall in Pelotas/RS: trend, associated synoptic systems and PDO influence). Revista Brasileira de Geografia Física, [S.I.], v. 11, n. 4, p. 1429-1441, out. 2018. ISSN 1984-2295. Disponível em: https://periodicos.ufpe.br/revistas/rbgfe/article/view/234526. Acesso em: 17 jun. 2019. doi:https://doi.org/10.26848/rbgf.v11.4.p1429-1441.

CAMPOS, Thamiris Luisa de Oliveira Brandão; MOTA, Maria Aurora Santos da; SANTOS, Sergio Rodrigo Quadros dos. Eventos extremos de precipitação em Belém-PA: uma revisão de notícias históricas de jornais. Rev. Ambient. Água, Taubaté , v. 10, n. 1, p. 182-194, Mar. 2015. Available from http://www.scielo.br/scielo.php?script=sci_arttext\&pid=S1980-

993X2015000100182\&lng=en\&nrm=iso. access on 03 May 2019. http://dx.doi.org/10.4136/ambi-agua.1433.

CAVALCANTI, I. F. A. . Large scale and synoptic features associated with extreme precipitation over South America: A review and case studies for the first decade of the 21st century. Atmospheric Research (Print), v. 118, p. 27-40, 2012. Available from Acesso em 12 Nov. 2017. http://dx.doi.org/10.1016/j.atmosres.2012.06.012.

CENTRO DE PESQUISAS METEOROLÓGICAS E CLIMÁTICAS APLICADAS À AGRICULTURA (CEPAGRI). Clima dos municípios paulistas. Disponível em: http://www.cpa.unicamp.br/outras-informacoes/clima-dos municipiospaulistas.html. Acesso em 07 de setembro de 2018. 
CONTI, J. B. Circulação secundária e efeito orográfico na gênese das chuvas na região lesnordeste paulista. Tese (Doutorado). Instituto de Geografia, Universidade de São Paulo, São Paulo, 1975.

CONTI, J. B. Resgatando a "Fisiologia da Paisagem". Revista do Departamento de Geografia, v. 14, p. 59-68, 2001.

CRESPO, A. A.; Estatística Fácil. 18 ed. São Paulo: Saraiva, 2002, p. 224.

CRUZ, O. A Serra do Mar e o litoral na área de Caraguatatuba: Contribuição à Geomorfologia Litorânea Tropical. Série Teses e Monografias №11, São Paulo, 1974.

CRUZ, O. A Serra do Mar e a Preservação de suas vertentes. Revista Orientação, São Paulo, n. 7, p. 39-45, 1986.

DEPARTAMENTO DE ÁGUAS E ENERGIA ELÉTRICA (DAEE). Banco de dados hidrológicos. Disponível em: < http://www.hidrologia.daee.sp.gov.br/>. Acesso em 20 de junho de 2019.

DOSWELL, C. A., III; BROOKS H. E.; MADDOX R. A. Flash flood forecasting: An ingredients-based methodology. Weather and Forecasting, 11, 560-581, 1996.

DUNLOP, Storm. Definição de evento extremo. A Dictionary of Weather. : Oxford University Press, January 01, 2008. Oxford Reference. Disponível em: http://www.oxfordreference.com/view/10.1093/acref/9780199541447.001.0001/acref9780199541447-e-2465. Acesso em 02 de maio de 2019.

EMPRESA BRASILEIRA DE PESQUISA AGROPECUÁRIA (EMBRAPA). Agência Embrapa de Informação Tecnológica: Solos tropicais - Saturação por bases. Disponível em: http://www.agencia.cnptia.embrapa.br. Acesso em 20 de novembro de 2018.

EMPRESA PAULISTA DE PLANEJAMENTO METROPOLITANO S/A (EMPLASA). Região Metropolitana do Vale do Paraíba e Litoral Norte: sobre a RMVPLN. Disponível em: https://www.emplasa.sp.gov.br/RMVPLN. Acesso em 07 de setembro de 2018.

ESPÍRITO SANTO, C. M.; SATYAMURTY P. Eventos Extremos de Precipitação na Região Sudeste do Brasil e redondezas no período de 1997-2001. In: XII Congresso Brasileiro de Meteorologia, 2002, Foz do Iguaçu, PR. Anais do XII Congresso de Meteorologia, 2002.

FIGUEIREDO, J.C.; Scolar, J. Estudo da trajetória dos sistemas convectivos de mesoescala na América do Sul. VII Congreso Argentino de Meteorologia e VII Congreso Latinoamericano e Ibérico de Meteorologia, Buenos Aires, Argentina, Setembro 1996, 165-166.

FURLAN, S. A. INDICADORES BIOGEOGRÁFICOS EM FRAGMENTOS DE MATA ATLÂNTICA INSULAR E CONTINENTAL E SUAS POSSÍVEIS IMPLICAÇÕES 
PALEOAMBIENTAIS. Revista do Departamento de Geografia, v. 10, p. 13-28, 1996.

GALVANI, E. LIMA, N. G. B. As classificações pluviométricas do estado de São Paulo: uma revisão bibliográfica. In: Galvani, E; Lima, N.G.B. (org.). Climatologia aplicada: resgate aos estudos de caso. $1^{\text {a }}$ ed. Curitiba: CRV, 2012, 196p.

GALVANI, E. LUCHIARI, A. Critérios para a classificação de anos com regime pluviométrico normal, seco e úmido. In: Galvani, E; Lima, N.G.B. (org.). Climatologia aplicada: resgate aos estudos de caso. $1^{\underline{a}}$ ed. Curitiba: CRV, 2012, 196p.

GUERRA, A. T. Novo dicionário geológico-geomorfológico. Rio de Janeiro: Bertrand Brasil, 6ª ed, 2008. 652p.

INSTITUTO BRASILEIRO DE GEOGRAFIA E ESTATÍSTICA (IBGE). Dados dos municípios do estado de São Paulo. Disponível em: < http://www.cidades.ibge.gov.br/>. Acesso em 07 de setembro de 2018.

INSTITUTO NACIONAL DE METEOROLOGIA (INMET). Normal Climatológica do Brasil 1961-1990. Disponível em: http://www.inmet.gov.br/portal/index.php?r=clima/normaisclimatologicas. Acesso em 07 de setembro de 2018.

INSTITUTO DE PESQUISAS TECNOLÓGICAS DO ESTADO DE SÃO PAULO IPT. Mapeamento e proposta de plano de gerenciamento de áreas de risco de escorregamentos do município de Caraguatatuba, SP. Parecer técnico 18 578-301. São Paulo, 2010.

JONGJIN, B.; JONGMIN, P.; DONGRYEOL, R; MINHA, C. Geospatial blending to improve spatial mapping of precipitation with high spatial resolution by merging satellitebased and ground-based data. Hydrol. Process. v. 30, p. 2789-2803, 2016. Disponível em: http://onlinelibrary.wiley.com/doi/10.1002/hyp.10786/abstract. DOI: 10.1002/hyp.10786.

JOHNSON, F.; HUTCHINSON, M.F.; THE, C.; BEESLEY, C.; GREEN, J. Topographic relationships for design rainfalls over Australia. Journal of Hydrology, v. 533, p. 439-451, 2015. Disponível em: http://www.sciencedirect.com/science/article/pii/S002216941500983X. Acesso em 11 de dezembro de 2017. http://dx.doi.org/10.1016/j.jhydrol.2015.12.035.

KOGA VICENTE, Andrea; Nunes, Luci Hidalgo. Impactos socioambientais associados à precipitação em municípios do litoral paulista. GEOGRAFIA, Rio Claro, v. 36, n. 3, p. 571-588, set./dez. 2011.

LOVINO, M.; GARCÍA, N. O.; BAETHGEN, W. Spatiotemporal analysis of extreme precipitation events in the Northeast region of Argentina (NEA). Journal of Hydrology: Regional Studies, v. 2, p. 140-158, 2014. Disponível em: http://www.sciencedirect.com/science/article/pii/S2214581814000287.

http://dx.doi.org/10.1016/j.ejrh.2014.09.001. 
MENDONÇA, F.; DANNI-OLIVEIRA, I.M. Climatologia: noções básicas e climas do Brasil. São Paulo: Oficina de Textos, 2007, 206 p.

MILANESI, M. A. Avaliação do efeito orográfico na pluviometria de vertentes opostas da Ilha de São Sebastião (Ilhabela - SP). Dissertação (mestrado). Faculdade de Filosofia, Letras e Ciências Humanas, Universidade de São Paulo, São Paulo, 2007.

MILANESI, Marcos Alexandre; GALVANI, Emerson. EFEITO OROGRÁFICO NA ILHA DE SÃO SEBASTIÃO (ILHABELA - SP). Revista Brasileira de Climatologia, [S.I.], v. 9, dez. 2011. ISSN 2237-8642. Disponível em: https://revistas.ufpr.br/revistaabclima/article/view/27516. Acesso em: 05 nov. 2019. doi:http://dx.doi.org/10.5380/abclima.v9i0.27516.

MONTEIRO, C.A.F. Clima. Grande Região Sul. Rio de Janeiro: IBGE, 1968. v. 4, t. 1, p. 114-166.

MONTEIRO, C.A.F. Análise Rítmica em Climatologia: problemas da atualidade climática em São Paulo e achegas para um programa de trabalho. São Paulo: Universidade de São Paulo/Instituto de Geografia, 1971. 21 p. (Série Climatologia n 1).

MONTEIRO, C.A.F. A dinâmica climática e as chuvas no estado de São Paulo: estudo sob a forma de atlas. Laboratório de Climatologia, Instituto de Geografia, Universidade de São Paulo, 1973, 130 p.

MONTEIRO, C.A.F. Teoria e Clima Urbano: um projeto e seus caminhos. In: MONTEIRO, C. A. F.; MENDONÇA, F. Clima Urbano. São Paulo: Contexto, 2003. p. $9-67$.

MONTEIRO, J. B., ZANELLA, M. E. A metodologia dos máximos de precipitação aplicada ao estudo de eventos extremos diários nos municípios de Crato, Fortaleza e Sobral-CE. Geotextos, Volume 13, Ano 13, n. 2, dez. 2017. Disponível em: < https://portalseer.ufba.br/index.php/geotextos/article/view/24011>. Acesso em 09 de maio de 2019.

NERY, J.T., CARFAN, A.C. AND MARTIN-VIDE, J. (2017) Analysis of Rain Variability Using the Daily and Monthly Concentration Indexes in Southeastern Brazil. Atmospheric and Climate Sciences, 7, 176-190. Disponível em: <https://doi.org/10.4236/acs.2017.72013>. Acesso em 14 de outubro de 2017.

NUNES, L. H.. Estudo da normalidade da pluviometria no setor serrano de Cubatão e Baixada Santista. Revista do Departamento de Geografia, São Paulo, n.6, p. 3143, 1992.

OLIVEIRA, M. R.; GALVANI, E. Eventos Extremos de Precipitação no Perfil Longitudinal Paraty (RJ) - Campos do Jordão (SP). Revista do Departamento de Geografia, n. spe, p. 58-66, 27 jun. 2017.

PELLEGATTI, C.H.G. Avaliação espaço-temporal da precipitação no perfil da Baixada Santista - Vertentes Ocêanicas-Rebordo Interiorano da escarpa da 
Serra do Mar - SP. Dissertação (mestrado). Faculdade de Filosofia, Letras e Ciências Humanas, Universidade de São Paulo, São Paulo, 2007.

RAMOS, A. M.; SANTOS, L. A. R.; FORTES, L. T. G. Normais Climatológicas do Brasil 1961-1990 / DF: INMET, 465 p. ISBN: 978-85-62817-01-4, 2009.

REBOITA, Michelle Simões et al. Entendendo o tempo e o clima na América do Sul. Terrae Didatica, Campinas, SP, v. 8, n. 1, p. 34-50, jun. 2015. ISSN 1980-4407. Disponível em: <https://periodicos.sbu.unicamp.br/ojs/index.php/td/article/view/8637425>. Acesso em: 09 maio 2019. doi:https://doi.org/10.20396/td.v8i1.8637425.

REIS, André Luiz dos et al. Climatologia e eventos extremos de precipitação no estado de Minas Gerais (Climatology and extreme rainfall events in the state of Minas Gerais). Revista Brasileira de Geografia Física, [S.I.], v. 11, n. 2, p. 652-660, jun. 2018. ISSN 1984-2295. Disponível em: <https://periodicos.ufpe.br/revistas/rbgfe/article/view/234146>. Acesso em: 17 jun. 2019. doi:https://doi.org/10.26848/rbgf.v11.2.p652-660.

RIBEIRO, A. G. As escalas do clima. Boletim de Geografia Teorética., v. 23, n.4546, p. 288-294, 1993.

RIEHL, H. Meteorologia Tropical. Tradução de Aurélio Augusto Rocha. Rio de Janeiro: Ao livro técnico S/A, 1965. 426 p.

ROSS, J.; MOROZ, I. MAPA GEOMORFOLÓGICO DO ESTADO DE SÃO PAULO. Revista do Departamento de Geografia, v. 10, p. 41-58, 1996.

ROSSI, M. 2017. Mapa pedológico do Estado de São Paulo: revisado e ampliado. São Paulo: Instituto Florestal, 2017. V.1. 118p. (inclui Mapas).

SACRAMENTO NETO, O. B.; ESCOBAR, G. C. J. ; SILVA, P. E. D. Método objetivo para identificar episódios de Zonas de Convergência de Umidade (ZCOU) no ambiente operacional do Centro de Previsão de Tempo e Estados Climáticos CPTEC. In: XVI CONGRESSO BRASILEIRO DE METEOROLOGIA, 2010, Belém do Pará. Anais... Belém do Pará, 2010.

SANT'ANNA NETO, J. L.. Ritmo climático e a gênese das chuvas na zona costeira paulista. Dissertação (mestrado). Faculdade de Filosofia, Letras e Ciências Humanas, Universidade de São Paulo, São Paulo, 1990.

SANT'ANNA NETO, João Lima. DECÁLOGO DA CLIMATOLOGIA DO SUDESTE BRASILEIRO. Revista Brasileira de Climatologia, [S.I.], v. 1, dez. 2005. ISSN 2237-8642. Disponível

em: <https://revistas.ufpr.br/revistaabclima/article/view/25232>. Acesso em: 02 maio 2019. doi:http://dx.doi.org/10.5380/abclima.v1i1.25232.

SANTOS, D. D. As chuvas em Caraguatatuba (SP): análise de variabilidade e eventos extremos em diferentes escalas temporais. Trabalho de Graduação Individual. Faculdade de Filosofia, Letras e Ciências Humanas, Universidade de São Paulo, São Paulo, 2015. 
SANTOS, Denise Dias dos; GALVANI, Emerson. DISTRIBUIÇÃO SAZONAL E HORÁRIA DAS PRECIPITAÇÕES EM CARAGUATATUBA-SP E A OCORRÊNCIA DE EVENTOS EXTREMOS NOS ANOS DE 2007 A 2011. Ciência e Natura, [S.I.], v. 36 , n. 2, p. 214-229, maio 2014. ISSN 2179-460X. Disponível em: <https://periodicos.ufsm.br/cienciaenatura/article/view/11891>. Acesso em: 12 nov. 2017. doi:http://dx.doi.org/10.5902/2179460X11891.

SANTOS, D. D.; MORAES, S. L.; GALVANI, E. Variação da temperatura do ar média, mínima e máxima no perfil topoclimático da trilha Caminhos do Mar (SP). Revista Equador, Vol. 5, ㄲ5, 2016, p.01-19.

SECRETARIA DO MEIO AMBIENTE DO ESTADO DE SÃO PAULO - INSTITUTO PLORESTAL. Plano de Manejo do Parque Estadual da Serra do Mar (Diagnóstico e Avaliação do Meio Físico). São Paulo: SMA/IF, 2006.

SEIXAS, Sônia Regina da Cal et al . Percepção de pescadores e maricultores sobre mudanças ambientais globais, no Litoral Norte Paulista, São Paulo, Brasil. RGCI, Lisboa, v. 14, n. 1, p. 51-64, mar. 2014. Disponível em $<$ http://www.scielo.mec.pt/scielo.php?script=sci_arttext\&pid=S1646-

88722014000100005\&lng=pt\&nrm=iso>. Acesso em 03 maio 2019. http://dx.doi.org/10.5894/rgci424.

SENTELHAS, P. C.; PEREIRA, A. R.; MARIN, F.R.; ANGELOCCI, L.R.; ALFONSI, R.R.; CARAMORI, P.H.; SWART, S. BHBRASIL - Balanços hídricos climatológicos de 500 localidades brasileiras. Piracicaba: ESALQ/USP, 1999. 7p.

SERAFINI JÚNIOR, S.; GALVANI, E.; LIMA, N. G. B.; ALVES, R. R. Adequação da escala climatológica para os planos de manejo: o Parque Estadual Intervales como estudo de caso. In: Galvani, E; Lima, N. G. B. (org.). Climatologia aplicada: resgate aos estudos de caso. $1^{\text {a }}$ ed. Curitiba: CRV, 2012, 196p.

SETZER, J. Contribuição para o Estudo do Clima do Estado de São Paulo. Separata atualizada do "Boletim D.E.R. ", IX X, XI, São Paulo, 1946. 239 p.

SILVA, A.C. O Litoral Norte do Estado de São Paulo (Formação de uma Região Periférica). Tese (doutorado). Faculdade de Filosofia, letras e Ciências Humanas, Universidade de São Paulo, São Paulo, 1975.

SILVA, A. C.; SANT'ANNA NETO, J. L.; TOMMASELLI, J. T. G.; TAVARES, R. Caracterização das chuvas no LNP. Cosmos, Presidente Prudente, v. 3, n.5, p. 3948, 2005.

SILVA, M. E.; SILVA, C. VARIABILIDADE CLIMÁTICA - PROCESSOS FÍSICOS E DINÂMICOS NOS OCEANOS E ATMOSFERA. Revista do Departamento de Geografia, p. 372-406, 27 dez. 2012.

SILVA DIAS, M.A.F. Complexos Convectivos de Mesoescala. In: CPTEC/INPE. (Org.). CLIMANÁLISE ESPECIAL. SÃO JOSÉ DOS CAMPOS: INPE, 1996. 
SILVA DIAS, M. A. F.; ROZANTE, J.R. ; MACHADO, L. A. T. Complexos convectivos de mesoescala na América do Sul. In: I. Cavalcanti; N. J. Ferreira, M. A. F.Silva Dias; M. G. A. Justi da Silva. (Org.). Tempo e Clima no Brasil. 1ª ed. São Paulo: Oficina de Textos, 2009, v. 1, p. 181-194.

SOBRAL, Bruno Serafini et al. VARIABILIDADE ESPAÇO-TEMPORAL E INTERANUAL DA CHUVA NO ESTADO DO RIO DE JANEIRO. Revista Brasileira de Climatologia, [S.I.], v. 22, maio 2018. ISSN 2237-8642. Disponível em: $<$ https://revistas.ufpr.br/revistaabclima/article/view/55592>. Acesso em: 04 maio 2019. doi:http://dx.doi.org/10.5380/abclima.v22i0.55592.

SORRE, M. Objeto e método da climatologia. Tradução de José Bueno Conti. Revista do Departamento de Geografia, n.18, p. 89-94, 2006.

SOUZA, C.R.G. PRAIAS ARENOSAS OCEÂNICAS DO ESTADO DE SÃO PAULO (BRASIL): SÍNTESE DOS CONHECIMENTOS SOBRE MORFODINÂMICA, SEDIMENTOLOGIA, TRANSPORTE COSTEIRO E EROSÃO COSTEIRA. Revista do Departamento de Geografia, p. 308-371, 27 dez. 2012.

TAVARES, R. Clima, tempo e desastres. In: Tominaga, L. K.; Santoro, J. Amaral, R. (orgs.). Desastres naturais: conhecer para prevenir. $2^{2}$ ed. São Paulo: Instituto Geológico, 2012, 196p.

TEODORO, P. E.; OlIVEIRA JÚNIOR, J. F.; CUNHA, E. R.; CORREA, C. C. G.; TORRES, F. E.; BACANI, V. M.; GOIS, G.; RIBEIRO, L. P. Cluster analysis applied to the spatial and temporal variability of monthly rainfall in Mato Grosso do Sul State, Brazil. Meteorol. Atmos. Phys. v. 128, p. 197-209, 2015. Disponível em:<http://link.springer.com/article/10.1007/s00703-015-0408-y>. DOI 10.1007/s00703-015-0408-y.

TERASSI, Paulo Miguel de Bodas; GALVANI, Emerson. O EFEITO OROGRÁFICO DA SERRA DO MAR E O POTENCIAL EROSIVO DAS CHUVAS NAS BACIAS HIDROGRÁFICAS DO RIBEIRA E LITORÂNEA - PARANÁ. Revista Brasileira de Climatologia, [S.I.], v. 21, nov. 2017. ISSN 2237-8642. Disponível em: $<$ https://revistas.ufpr.br/revistaabclima/article/view/47621>. Acesso em: 04 maio 2019. doi:http://dx.doi.org/10.5380/abclima.v21i0.47621.

TITARELLI, A.H.V. A Serra do Mar. Orientação, São Paulo, v.7 , p.86-93, dez. 1986.

TOMINAGA, L.K. Desastres Naturais: por que ocorrem? In: Tominaga, L. K.; Santoro, J. Amaral, R. (org.). Desastres naturais: conhecer para prevenir. $2^{\mathrm{a}}$ ed. São Paulo: Instituto Geológico, 2012, 196p.

TUBELIS, A.; NASCIMENTO, F.J.L. Meteorologia Descritiva: fundamentos e aplicações brasileiras. São Paulo: Nobel. 1ํㅡㄹ Ed., 3ª reimpressão. 1984. 374 p.

VAREJÃO-SILVA, M. A. Meteorologia e Climatologia. Recife: Versão Digital, 2006, $449 \mathrm{p}$. 
VARIKODEN, $H$. et al. Seasonal variation of rainfall characteristics in different intensity classes over Peninsular Malaysia. Journal of Hydrology, v. 404, n. 1, p. 99-108, 2011/06/29/ 2011. ISSN 0022-1694. Disponível em: < https://doi.org/10.1016/j.jhydrol.2011.04.021 >. Acesso em 07 de setembro de 2018.

XAVIER, T. M. B. S.; XAVIER, A. F. S.; ALVES, J. M. B. Quantis e Eventos Extremos: aplicações em ciências da terra e ambientais. Fortaleza: RDS Editora, 2007. 278p.

WANDERLEY, Lucas Suassuna de Albuquerque et al. AS CHUVAS NA CIDADE DO RECIFE: UMA CLIMATOLOGIA DE EXTREMOS. Revista Brasileira de Climatologia, [S.I.], v. 22, fev. 2018. ISSN 2237-8642. Disponível em: <https://revistas.ufpr.br/revistaabclima/article/view/56034>. Acesso em: 04 maio 2019. doi:http://dx.doi.org/10.5380/abclima.v22i0.56034.

WORLD METEOROLOGICAL ORGANIZATION (WMO). Calculation of monthly and annual 30-year standard normals. Geneva. WMO. Technical document, n. 341; WCDP, n.10, 1989.

ZANELLA, M. E. Eventos pluviométricos intensos e impactos gerados na Cidade de Curitiba/PR - bairro Cajuru: um destaque para as inundações urbanas. Mercator Revista de Geografia da UFC, ano 05, número 09, 2006, p. 61-69.

ZHU, Y.; THOT, Z. Extreme weather events and their probabilistic prediction by the NCEP ensembly forecast system. In: Preprints for the symposium on the precipitacion Extrems: Prediction, impacts and responses, 2001, Albuquerque. Proceedings...Boston: AMS, 2001.2 Disponível em: http://www.emc.ncep.noaa.gov/gmb/ens/target/ens/albapr/albapr.html. Acesso em 13 de setembro de 2017. 
ANEXOS 
Ocorrência dos eventos extremos nos postos pluviométricos da área de estudo (por posto, precipitação em mm). Fonte: DAEE. Org.: Santos, 2019.

\begin{tabular}{|c|c|c|c|c|}
\hline Dia & Mês & Ano & Estação & E2-042 \\
\hline 9 & março & 1943 & Verão & 80,0 \\
\hline 19 & fevereiro & 1944 & Verão & 215,2 \\
\hline 24 & novembro & 1944 & Primavera & 145,9 \\
\hline 8 & janeiro & 1945 & Verão & 87,5 \\
\hline 2 & fevereiro & 1945 & Verão & 86,6 \\
\hline 4 & março & 1945 & Verão & 186,0 \\
\hline 5 & março & 1945 & Verão & 122,3 \\
\hline 2 & setembro & 1945 & Inverno & 87,1 \\
\hline 20 & janeiro & 1946 & Verão & 91,5 \\
\hline 29 & setembro & 1946 & Primavera & 75,1 \\
\hline 9 & outubro & 1946 & Primavera & 75,4 \\
\hline 16 & dezembro & 1946 & Primavera & 82,0 \\
\hline 20 & abril & 1947 & Outono & 87,2 \\
\hline 21 & junho & 1947 & Inverno & 76,0 \\
\hline 1 & abril & 1948 & Outono & 91,2 \\
\hline 19 & outubro & 1949 & Primavera & 110,0 \\
\hline 13 & maio & 1953 & Outono & 87,4 \\
\hline 6 & maio & 1954 & Outono & 99,8 \\
\hline 17 & outubro & 1955 & Primavera & 105,3 \\
\hline 21 & novembro & 1955 & Primavera & 120,8 \\
\hline 26 & maio & 1956 & Outono & 82,3 \\
\hline 30 & outubro & 1957 & Primavera & 82,4 \\
\hline 16 & dezembro & 1958 & Primavera & 95,0 \\
\hline 22 & dezembro & 1958 & Verão & 85,0 \\
\hline 14 & fevereiro & 1962 & Verão & 83,4 \\
\hline 21 & fevereiro & 1962 & Verão & 84,7 \\
\hline 4 & abril & 1962 & Outono & 85,5 \\
\hline 2 & abril & 1964 & Outono & 82,8 \\
\hline 19 & janeiro & 1965 & Verão & 77,0 \\
\hline 18 & julho & 1965 & Inverno & 81,7 \\
\hline 24 & outubro & 1967 & Primavera & 90,2 \\
\hline 16 & novembro & 1967 & Primavera & 90,0 \\
\hline 10 & dezembro & 1967 & Primavera & 90,2 \\
\hline 20 & dezembro & 1967 & Primavera & 90,0 \\
\hline 25 & dezembro & 1967 & Verão & 80,0 \\
\hline 27 & dezembro & 1969 & Verão & 80,0 \\
\hline 27 & janeiro & 1970 & Verão & 75,4 \\
\hline 14 & março & 1970 & Verão & 90,4 \\
\hline 15 & março & 1970 & Verão & 100,8 \\
\hline
\end{tabular}




\begin{tabular}{|c|c|c|c|c|}
\hline Dia & Mês & Ano & Estação & E2-043 \\
\hline 19 & fevereiro & 1944 & Verão & 202,6 \\
\hline 24 & novembro & 1944 & Primavera & 169,3 \\
\hline 4 & março & 1945 & Verão & 162,9 \\
\hline 5 & março & 1945 & Verão & 155,6 \\
\hline 26 & janeiro & 1947 & Verão & 149,7 \\
\hline 19 & fevereiro & 1947 & Verão & 104,3 \\
\hline 20 & abril & 1947 & Outono & 138,6 \\
\hline 21 & dezembro & 1947 & Verão & 133,3 \\
\hline 19 & dezembro & 1948 & Primavera & 103,2 \\
\hline 26 & janeiro & 1949 & Verão & 100,0 \\
\hline 19 & outubro & 1949 & Primavera & 128,8 \\
\hline 21 & janeiro & 1950 & Verão & 110,0 \\
\hline 21 & outubro & 1951 & Primavera & 141,2 \\
\hline 22 & fevereiro & 1952 & Verão & 160,1 \\
\hline 23 & fevereiro & 1952 & Verão & 104,1 \\
\hline 1 & novembro & 1953 & Primavera & 102,1 \\
\hline 4 & novembro & 1953 & Primavera & 102,5 \\
\hline 5 & dezembro & 1953 & Primavera & 102,4 \\
\hline 30 & outubro & 1957 & Primavera & 129,6 \\
\hline 16 & fevereiro & 1959 & Verão & 122,6 \\
\hline 17 & fevereiro & 1959 & Verão & 196,6 \\
\hline 8 & fevereiro & 1960 & Verão & 123,0 \\
\hline 13 & fevereiro & 1960 & Verão & 114,6 \\
\hline 26 & janeiro & 1961 & Verão & 160,4 \\
\hline 1 & março & 1961 & Verão & 99,6 \\
\hline 9 & março & 1964 & Verão & 109,1 \\
\hline 20 & janeiro & 1965 & Verão & 99,7 \\
\hline 20 & abril & 1965 & Outono & 182,7 \\
\hline 24 & dezembro & 1966 & Verão & 110,0 \\
\hline 13 & janeiro & 1967 & Verão & 200,9 \\
\hline 18 & março & 1967 & Verão & 195,5 \\
\hline 24 & outubro & 1967 & Primavera & 194,6 \\
\hline 26 & abril & 1968 & Outono & 203,8 \\
\hline 19 & fevereiro & 1969 & Verão & 120,8 \\
\hline 18 & novembro & 1969 & Primavera & 106,0 \\
\hline 25 & novembro & 1969 & Primavera & 290,0 \\
\hline 14 & janeiro & 1970 & Verão & 104,5 \\
\hline 11 & maio & 1971 & Outono & 120,4 \\
\hline
\end{tabular}




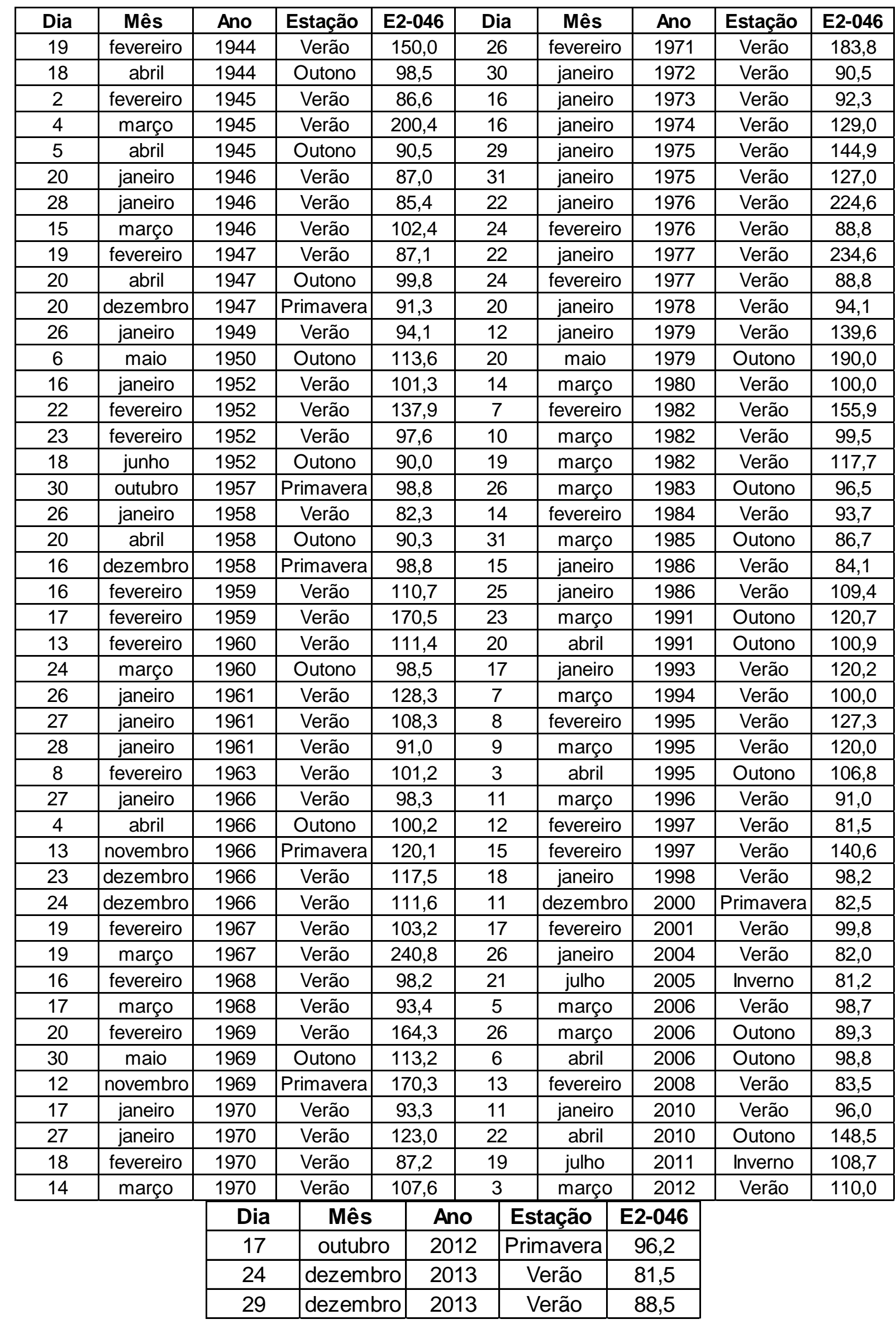




\begin{tabular}{|c|c|c|c|c|}
\hline Dia & Mês & Ano & Estação & E2-128 \\
\hline 2 & fevereiro & 1971 & Verão & 189,3 \\
\hline 26 & fevereiro & 1971 & Verão & 131,7 \\
\hline 30 & janeiro & 1972 & Verão & 129,8 \\
\hline 5 & abril & 1972 & Outono & 86,4 \\
\hline 6 & julho & 1972 & Inverno & 85,7 \\
\hline 4 & maio & 1973 & Outono & 95,0 \\
\hline 22 & janeiro & 1976 & Verão & 90,4 \\
\hline 14 & abril & 1976 & Outono & 91,2 \\
\hline 28 & setembro & 1976 & Primavera & 115,2 \\
\hline 19 & janeiro & 1977 & Verão & 95,8 \\
\hline 22 & dezembro & 1977 & Verão & 89,1 \\
\hline 12 & janeiro & 1978 & Verão & 101,3 \\
\hline 20 & abril & 1978 & Outono & 99,8 \\
\hline 2 & maio & 1978 & Outono & 88,7 \\
\hline 28 & janeiro & 1979 & Verão & 126,8 \\
\hline 31 & março & 1980 & Outono & 117,3 \\
\hline 18 & março & 1981 & Verão & 94,2 \\
\hline 3 & janeiro & 1982 & Verão & 172,9 \\
\hline 7 & março & 1983 & Verão & 130,2 \\
\hline 22 & março & 1984 & Outono & 99,7 \\
\hline 20 & setembro & 1984 & Inverno & 133,9 \\
\hline 4 & dezembro & 1984 & Primavera & 263,2 \\
\hline 14 & fevereiro & 1985 & Verão & 447,2 \\
\hline 10 & junho & 1985 & Outono & 87,6 \\
\hline 3 & abril & 1987 & Outono & 86,0 \\
\hline 21 & dezembro & 1988 & Verão & 90,0 \\
\hline 8 & maio & 1989 & Outono & 88,3 \\
\hline 11 & junho & 1989 & Outono & 88,4 \\
\hline 27 & dezembro & 1995 & Verão & 119,0 \\
\hline 30 & dezembro & 1995 & Verão & 87,4 \\
\hline 25 & maio & 1997 & Outono & 89,7 \\
\hline & & & & \\
\hline
\end{tabular}




\begin{tabular}{|c|c|c|c|c|}
\hline Dia & Mês & Ano & Estação & $\mathbf{E 1 - 0 0 3}$ \\
\hline 5 & abril & 1945 & Outono & 152,6 \\
\hline 25 & janeiro & 1947 & Verão & 251,4 \\
\hline 20 & abril & 1947 & Outono & 191,3 \\
\hline 21 & junho & 1947 & Inverno & 133,7 \\
\hline 26 & janeiro & 1949 & Verão & 170,0 \\
\hline 6 & dezembro & 1950 & Primavera & 215,5 \\
\hline 8 & fevereiro & 1951 & Verão & 157,5 \\
\hline 24 & março & 1951 & Outono & 225,8 \\
\hline 25 & março & 1951 & Outono & 196,2 \\
\hline 15 & abril & 1951 & Outono & 151,9 \\
\hline 17 & janeiro & 1952 & Verão & 140,2 \\
\hline 7 & fevereiro & 1952 & Verão & 132,3 \\
\hline 15 & fevereiro & 1953 & Verão & 133,2 \\
\hline 2 & maio & 1954 & Outono & 137,5 \\
\hline 17 & fevereiro & 1956 & Verão & 169,2 \\
\hline 4 & novembro & 1957 & Primavera & 146,0 \\
\hline 16 & fevereiro & 1959 & Verão & 248,4 \\
\hline 19 & março & 1959 & Verão & 147,5 \\
\hline 20 & maio & 1959 & Outono & 168,0 \\
\hline 16 & fevereiro & 1961 & Verão & 150,0 \\
\hline 15 & junho & 1961 & Outono & 137,9 \\
\hline 16 & janeiro & 1962 & Verão & 146,7 \\
\hline 10 & fevereiro & 1962 & Verão & 178,2 \\
\hline 30 & março & 1963 & Outono & 240,0 \\
\hline 20 & abril & 1965 & Outono & 198,5 \\
\hline 21 & abril & 1965 & Outono & 153,0 \\
\hline 16 & dezembro & 1965 & Primavera & 256,2 \\
\hline 8 & abril & 1966 & Outono & 251,0 \\
\hline 24 & dezembro & 1966 & Verão & 146,4 \\
\hline 24 & janeiro & 1967 & Verão & 351,9 \\
\hline 26 & janeiro & 1967 & Verão & 195,4 \\
\hline 19 & fevereiro & 1967 & Verão & 178,6 \\
\hline 10 & junho & 1969 & Outono & 186,4 \\
\hline 26 & abril & 1971 & Outono & 240,9 \\
\hline
\end{tabular}




\begin{tabular}{|c|c|c|c|c|c|c|c|c|c|}
\hline Dia & Mês & Ano & Estação & E1-004 & Dia & Mês & Ano & Estação & E1-004 \\
\hline 5 & abril & 1945 & Outono & 211,9 & 20 & janeiro & 1967 & Verão & 131,7 \\
\hline 25 & janeiro & 1947 & Verão & 224,8 & 23 & janeiro & 1967 & Verão & 303,0 \\
\hline 20 & abril & 1947 & Outono & 185,5 & 7 & março & 1967 & Verão & 294,8 \\
\hline 14 & junho & 1947 & Outono & 137,7 & 15 & março & 1967 & Verão & 180,0 \\
\hline 21 & junho & 1947 & Inverno & 170,3 & 1 & fevereiro & 1968 & Verão & 181,6 \\
\hline 16 & janeiro & 1948 & Verão & 140,9 & 17 & março & 1968 & Verão & 160,0 \\
\hline 4 & fevereiro & 1948 & Verão & 140,9 & 20 & fevereiro & 1969 & Verão & 200,6 \\
\hline 11 & fevereiro & 1948 & Verão & 151,7 & 26 & fevereiro & 1971 & Verão & 179,2 \\
\hline 12 & setembro & 1948 & Inverno & 135,8 & 2 & dezembro & 1981 & Primavera & 135,7 \\
\hline 6 & dezembro & 1950 & Primavera & 247,5 & 27 & \begin{tabular}{|l|} 
fevereiro \\
\end{tabular} & 1985 & Verão & 201,5 \\
\hline 24 & fevereiro & 1951 & Verão & 191,5 & 19 & março & 1986 & Verão & 297,0 \\
\hline 24 & março & 1951 & Outono & 193,3 & 18 & dezembro & 1986 & Primavera & 190,3 \\
\hline 25 & março & 1951 & Outono & 171,0 & 3 & abril & 1987 & Outono & 192,6 \\
\hline 15 & abril & 1951 & Outono & 151,4 & 1 & fevereiro & 1988 & Verão & 177,8 \\
\hline 7 & fevereiro & 1952 & Verão & 176,1 & 19 & fevereiro & 1988 & Verão & 217,3 \\
\hline 13 & dezembro & 1952 & Primavera & 130,4 & 11 & junho & 1989 & Outono & 175,8 \\
\hline 31 & março & 1955 & Outono & 144,8 & 15 & janeiro & 1992 & Verão & 133,5 \\
\hline 21 & novembro & 1955 & Primavera & 210,5 & 25 & novembro & 1992 & Primavera & 151,7 \\
\hline 2 & janeiro & 1956 & Verão & 150,2 & 2 & março & 1994 & Verão & 222,0 \\
\hline 5 & abril & 1957 & Outono & 186,3 & 12 & fevereiro & 1996 & Verão & 359,4 \\
\hline 4 & novembro & 1957 & Primavera & 140,0 & 13 & fevereiro & 1996 & Verão & 142,8 \\
\hline 1 & março & 1958 & Verão & 192,4 & 7 & outubro & 1997 & Primavera & 153,7 \\
\hline 3 & maio & 1958 & Outono & 221,8 & 7 & janeiro & 1998 & Verão & 127,5 \\
\hline 16 & fevereiro & 1959 & Verão & 313,8 & 8 & janeiro & 1998 & Verão & 137,2 \\
\hline 17 & fevereiro & 1959 & Verão & 161,0 & 11 & fevereiro & 1998 & Verão & 291,1 \\
\hline 29 & março & 1963 & Outono & 200,6 & 12 & \begin{tabular}{|l|} 
fevereiro \\
\end{tabular} & 1998 & Verão & 156,4 \\
\hline 16 & dezembro & 1965 & Primavera & 300,0 & 16 & fevereiro & 2000 & Verão & 145,0 \\
\hline 11 & janeiro & 1966 & Verão & 228,2 & & & & & \\
\hline
\end{tabular}




\begin{tabular}{|c|c|c|c|c|c|c|c|c|c|}
\hline Dia & Mês & Ano & Estação & E2-009 & Dia & Mês & Ano & Estação & E2-009 \\
\hline 22 & dezembro & 1958 & Verão & 135,5 & 9 & março & 1981 & Verão & 147,4 \\
\hline 8 & fevereiro & 1960 & Verão & 167,0 & 19 & março & 1981 & Verão & 182,3 \\
\hline 28 & outubro & 1960 & Primavera & 154,7 & 18 & abril & 1981 & Outono & 154,1 \\
\hline 31 & dezembro & 1960 & Verão & 139,0 & 12 & novembro & 1981 & Primavera & 143,9 \\
\hline 28 & janeiro & 1961 & Verão & 207,5 & 3 & dezembro & 1982 & Primavera & 140,4 \\
\hline 10 & fevereiro & 1961 & Verão & 251,3 & 24 & janeiro & 1985 & Verão & 262,4 \\
\hline 16 & fevereiro & 1961 & Verão & 180,5 & 23 & fevereiro & 1985 & Verão & 146,9 \\
\hline 1 & março & 1961 & Verão & 166,3 & 31 & março & 1985 & Outono & 135,6 \\
\hline 29 & julho & 1961 & Inverno & 172,3 & 1 & abril & 1985 & Outono & 192,1 \\
\hline 19 & dezembro & 1962 & Primavera & 152,4 & 19 & abril & 1985 & Outono & 151,6 \\
\hline 28 & dezembro & 1962 & Verão & 172,5 & 20 & março & 1986 & Outono & 253,0 \\
\hline 28 & março & 1963 & Outono & 228,5 & 19 & dezembro & 1986 & Primavera & 213,5 \\
\hline 15 & dezembro & 1965 & Primavera & 183,0 & 20 & dezembro & 1986 & Primavera & 171,0 \\
\hline 26 & janeiro & 1966 & Verão & 165,8 & 19 & janeiro & 1987 & Verão & 161,8 \\
\hline 7 & abril & 1966 & Outono & 179,2 & 4 & abril & 1987 & Outono & 209,2 \\
\hline 18 & fevereiro & 1967 & Verão & 157,2 & 6 & abril & 1987 & Outono & 137,6 \\
\hline 19 & fevereiro & 1967 & Verão & 189,8 & 21 & outubro & 1987 & Primavera & 135,2 \\
\hline 23 & outubro & 1967 & Primavera & 192,2 & 2 & fevereiro & 1988 & Verão & 162,5 \\
\hline 19 & fevereiro & 1969 & Verão & 271,5 & 21 & fevereiro & 1988 & Verão & 139,2 \\
\hline 26 & fevereiro & 1971 & Verão & 364,5 & 9 & março & 1988 & Verão & 170,0 \\
\hline 20 & novembro & 1971 & Primavera & 205,9 & 16 & novembro & 1988 & Primavera & 327,0 \\
\hline 9 & abril & 1972 & Outono & 140,8 & 12 & junho & 1989 & Outono & 151,4 \\
\hline 23 & setembro & 1972 & Primavera & 175,0 & 19 & abril & 1990 & Outono & 351,0 \\
\hline 17 & janeiro & 1973 & Verão & 305,3 & 17 & janeiro & 1992 & Verão & 293,8 \\
\hline 26 & janeiro & 1973 & Verão & 142,9 & 3 & maio & 1992 & Outono & 165,8 \\
\hline 7 & fevereiro & 1973 & Verão & 144,5 & 4 & maio & 1992 & Outono & 168,7 \\
\hline 11 & abril & 1973 & Outono & 151,8 & 27 & novembro & 1992 & Primavera & 242,7 \\
\hline 18 & dezembro & 1973 & Primavera & 137,8 & 19 & janeiro & 1993 & Verão & 192,5 \\
\hline 16 & janeiro & 1974 & Verão & 205,4 & 30 & março & 1993 & Outono & 198,0 \\
\hline 26 & fevereiro & 1975 & Verão & 134,5 & 30 & janeiro & 1994 & Verão & 150,0 \\
\hline 12 & outubro & 1975 & Primavera & 150,2 & 27 & março & 1995 & Outono & 150,3 \\
\hline 14 & dezembro & 1975 & Primavera & 170,6 & 13 & fevereiro & 1996 & Verão & 442,7 \\
\hline 22 & janeiro & 1976 & Verão & 298,4 & 14 & fevereiro & 1996 & Verão & 196,9 \\
\hline 16 & março & 1976 & Verão & 200,6 & 12 & fevereiro & 1998 & Verão & 139,3 \\
\hline 17 & março & 1976 & Verão & 170,1 & 12 & março & 1998 & Verão & 207,2 \\
\hline 18 & março & 1976 & Verão & 231,5 & 10 & dezembro & 2002 & Primavera & 147,3 \\
\hline 2 & abril & 1977 & Outono & 144,6 & 5 & abril & 2005 & Outono & 198,9 \\
\hline 11 & janeiro & 1978 & Verão & 294,1 & 2 & dezembro & 2005 & Primavera & 184,7 \\
\hline 13 & janeiro & 1980 & Verão & 152,0 & 8 & outubro & 2009 & Primavera & 151,2 \\
\hline 14 & janeiro & 1980 & Verão & 140,8 & 4 & dezembro & 2009 & Primavera & 196,7 \\
\hline 1 & abril & 1980 & Outono & 177,1 & 24 & abril & 2011 & Outono & 136,8 \\
\hline 14 & setembro & 1980 & Inverno & 300,0 & 25 & abril & 2011 & Outono & 149,5 \\
\hline 15 & setembro & 1980 & Inverno & 500,0 & 25 & dezembro & 2011 & Verão & 229,1 \\
\hline 9 & janeiro & 1981 & Verão & 156,2 & 16 & agosto & 2014 & Inverno & 136,0 \\
\hline 7 & fevereiro & 1981 & Verão & 158,1 & & & & & \\
\hline
\end{tabular}




\begin{tabular}{|c|c|c|c|c|c|c|c|c|c|}
\hline Dia & Mês & Ano & Estação & E2-052 & Dia & Mês & Ano & Estação & E2-052 \\
\hline 19 & abril & 1947 & Outono & 134,7 & 18 & outubro & 1982 & Primavera & 150,4 \\
\hline 25 & fevereiro & 1948 & Verão & 119,2 & 24 & janeiro & 1985 & Verão & 123,8 \\
\hline 11 & março & 1950 & Verão & 125,9 & 23 & fevereiro & 1985 & Verão & 186,2 \\
\hline 21 & março & 1950 & Outono & 165,3 & 1 & abril & 1985 & Outono & 120,7 \\
\hline 6 & dezembro & 1950 & Primavera & 171,6 & 4 & novembro & 1985 & Primavera & 137,5 \\
\hline 2 & janeiro & 1951 & Verão & 152,9 & 20 & março & 1986 & Outono & 173,3 \\
\hline 13 & janeiro & 1952 & Verão & 167,2 & 19 & dezembro & 1986 & Primavera & 127,5 \\
\hline 22 & fevereiro & 1952 & Verão & 162,2 & 4 & abril & 1987 & Outono & 156,4 \\
\hline 21 & novembro & 1955 & Primavera & 124,4 & 11 & dezembro & 1987 & Primavera & 189,0 \\
\hline 1 & janeiro & 1956 & Verão & 119,7 & 2 & fevereiro & 1988 & Verão & 277,5 \\
\hline 24 & fevereiro & 1957 & Verão & 117,8 & 20 & fevereiro & 1988 & Verão & 215,4 \\
\hline 22 & dezembro & 1958 & Verão & 115,5 & 21 & dezembro & 1988 & Verão & 117,0 \\
\hline 16 & fevereiro & 1959 & Verão & 187,1 & 28 & março & 1989 & Outono & 189,7 \\
\hline 17 & fevereiro & 1959 & Verão & 115,6 & 10 & junho & 1989 & Outono & 143,7 \\
\hline 8 & fevereiro & 1960 & Verão & 208,1 & 22 & março & 1990 & Outono & 182,9 \\
\hline 19 & dezembro & 1960 & Primavera & 129,7 & 19 & abril & 1990 & Outono & 273,0 \\
\hline 30 & dezembro & 1960 & Verão & 175,6 & 25 & outubro & 1990 & Primavera & 144,0 \\
\hline 29 & julho & 1961 & Inverno & 140,7 & 5 & janeiro & 1992 & Verão & 163,3 \\
\hline 16 & janeiro & 1962 & Verão & 141,9 & 17 & janeiro & 1992 & Verão & 218,3 \\
\hline 10 & fevereiro & 1962 & Verão & 231,2 & 26 & fevereiro & 1992 & Verão & 123,1 \\
\hline 29 & março & 1963 & Outono & 263,0 & 3 & maio & 1992 & Outono & 207,7 \\
\hline 20 & abril & 1965 & Outono & 197,6 & 27 & novembro & 1992 & Primavera & 184,7 \\
\hline 16 & dezembro & 1965 & Primavera & 247,5 & 19 & janeiro & 1993 & Verão & 118,2 \\
\hline 27 & janeiro & 1966 & Verão & 138,6 & 5 & março & 1993 & Verão & 126,4 \\
\hline 8 & abril & 1966 & Outono & 155,9 & 27 & março & 1993 & Outono & 115,0 \\
\hline 5 & maio & 1966 & Outono & 133,2 & 28 & março & 1993 & Outono & 116,0 \\
\hline 24 & dezembro & 1966 & Verão & 125,5 & 7 & fevereiro & 1994 & Verão & 180,4 \\
\hline 11 & fevereiro & 1967 & Verão & 137,7 & 13 & abril & 1994 & Outono & 148,3 \\
\hline 15 & março & 1967 & Verão & 170,5 & 13 & fevereiro & 1996 & Verão & 209,5 \\
\hline 20 & fevereiro & 1969 & Verão & 237,6 & 14 & fevereiro & 1996 & Verão & 146,5 \\
\hline 21 & novembro & 1969 & Primavera & 125,3 & 18 & abril & 2006 & Outono & 118,7 \\
\hline 10 & janeiro & 1970 & Verão & 174,0 & 11 & novembro & 2008 & Primavera & 176,8 \\
\hline 24 & fevereiro & 1970 & Verão & 244,5 & 5 & dezembro & 2009 & Primavera & 143,5 \\
\hline 26 & fevereiro & 1971 & Verão & 264,2 & 1 & janeiro & 2010 & Verão & 134,0 \\
\hline 15 & junho & 1973 & Outono & 143,6 & 26 & fevereiro & 2010 & Verão & 155,0 \\
\hline 20 & julho & 1973 & Inverno & 168,3 & 3 & março & 2011 & Verão & 127,0 \\
\hline 16 & janeiro & 1974 & Verão & 159,2 & 26 & dezembro & 2011 & Verão & 216,0 \\
\hline 18 & dezembro & 1976 & Primavera & 121,2 & 13 & fevereiro & 2012 & Verão & 118,2 \\
\hline 20 & abril & 1977 & Outono & 126,4 & 23 & fevereiro & 2013 & Verão & 114,6 \\
\hline 2 & março & 1979 & Verão & 157,8 & 18 & março & 2013 & Verão & 140,0 \\
\hline 9 & janeiro & 1981 & Verão & 117,7 & 16 & fevereiro & 2014 & Verão & 152,0 \\
\hline 19 & março & 1981 & Verão & 114,3 & & & & & \\
\hline
\end{tabular}




\begin{tabular}{|c|c|c|c|c|}
\hline Dia & Mês & Ano & Estação & E2-122 \\
\hline 25 & fevereiro & 1971 & Verão & 322,7 \\
\hline 16 & junho & 1973 & Outono & 161,2 \\
\hline 19 & julho & 1973 & Inverno & 210,3 \\
\hline 28 & setembro & 1976 & Primavera & 125,0 \\
\hline 18 & dezembro & 1976 & Primavera & 138,7 \\
\hline 20 & abril & 1977 & Outono & 119,2 \\
\hline 21 & abril & 1977 & Outono & 176,7 \\
\hline 11 & janeiro & 1978 & Verão & 173,0 \\
\hline 22 & fevereiro & 1979 & Verão & 185,1 \\
\hline 2 & março & 1979 & Verão & 156,5 \\
\hline 3 & março & 1979 & Verão & 132,5 \\
\hline 17 & dezembro & 1979 & Primavera & 120,8 \\
\hline 4 & fevereiro & 1980 & Verão & 165,5 \\
\hline 31 & março & 1980 & Outono & 130,5 \\
\hline 24 & janeiro & 1985 & Verão & 147,3 \\
\hline 23 & fevereiro & 1985 & Verão & 164,1 \\
\hline 4 & abril & 1987 & Outono & 152,5 \\
\hline 9 & fevereiro & 1988 & Verão & 410,0 \\
\hline 18 & fevereiro & 1991 & Verão & 128,8 \\
\hline 7 & janeiro & 1992 & Verão & 113,0 \\
\hline 3 & maio & 1992 & Outono & 112,3 \\
\hline 11 & fevereiro & 1993 & Verão & 143,0 \\
\hline 3 & março & 1993 & Verão & 135,3 \\
\hline 4 & março & 1993 & Verão & 147,7 \\
\hline 10 & dezembro & 1993 & Primavera & 125,0 \\
\hline 6 & fevereiro & 1994 & Verão & 386,6 \\
\hline 8 & junho & 1994 & Outono & 120,0 \\
\hline 18 & novembro & 1994 & Primavera & 145,0 \\
\hline 19 & fevereiro & 1995 & Verão & 118,7 \\
\hline 10 & março & 1995 & Verão & 158,7 \\
\hline 11 & fevereiro & 1996 & Verão & 214,3 \\
\hline 12 & fevereiro & 1996 & Verão & 171,1 \\
\hline 12 & fevereiro & 1998 & Verão & 120,0 \\
\hline 30 & janeiro & 2001 & Verão & 131,0 \\
\hline
\end{tabular}

